UNIVERSIDADE DE SÃO PAULO

FACULDADE DE ZOOTECNIA E ENGENHARIA DE ALIMENTOS

BRUNA EGYDIO DE SOUSA SANTOS

Estudo exploratório do mercado e da produção do Cavalo Brasileiro de Hipismo no Estado de São Paulo 
Estudo exploratório do mercado e da produção do Cavalo Brasileiro de Hipismo no Estado de São Paulo

"Versão corrigida"

Dissertação apresentada à Faculdade de Zootecnia e Engenharia de Alimentos da Universidade de São Paulo, como parte de requisitos para a obtenção do título de Mestre em Ciências.

Área de Concentração: Gestão na Indústria Animal.

Orientador: Prof. Dr. Augusto Hauber Gameiro. 
Ficha catalográfica elaborada pelo

Serviço de Biblioteca e Informação, FZEA/USP, com os dados fornecidos pelo(a) autor(a)

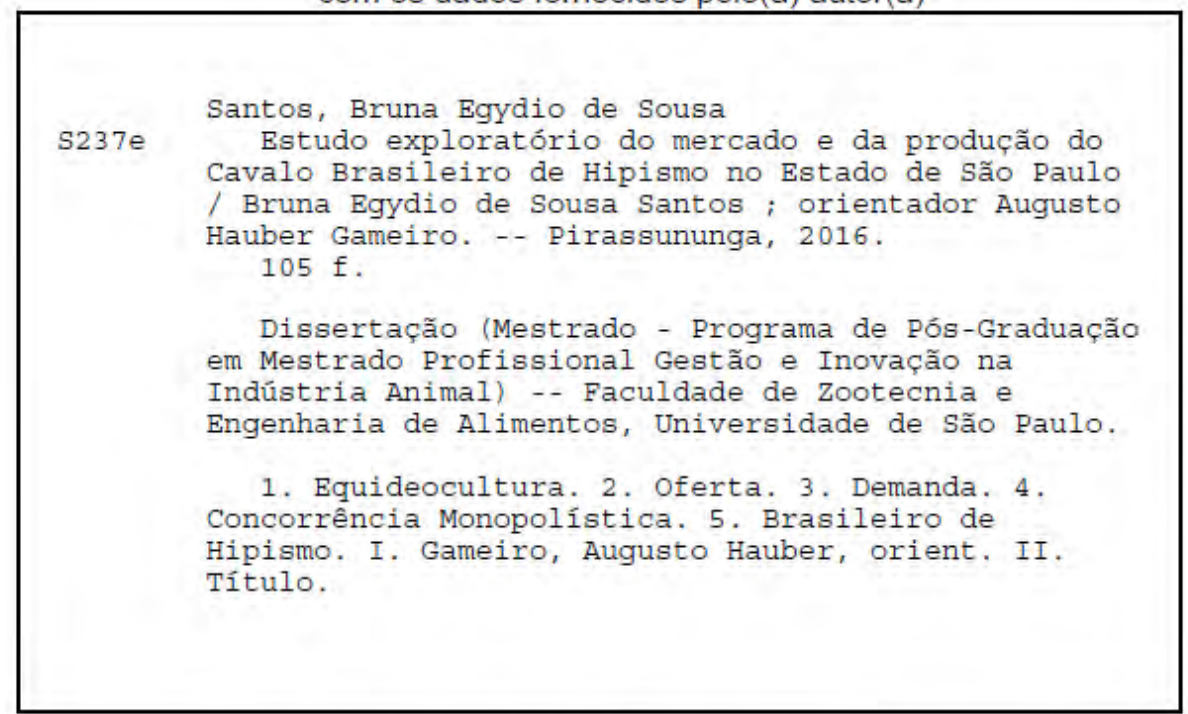

Permitida a copia total ou parcial deste documento, desde que citada a fonte - o autor 


\section{Estudo exploratório do mercado e da produção do Cavalo Brasileiro de Hipismo} no Estado de São Paulo

Dissertação apresentada à Faculdade de Zootecnia e Engenharia de Alimentos da Universidade de São Paulo, como parte de requisitos para a obtenção do título de Mestre em Ciências.

Área de Concentração: Gestão na Indústria Animal.

Data da aprovação:

Banca Examinadora:

Roberta Ariboni Brandi - Presidente da Banca Examinadora

Prof ${ }^{a}$. Dr ${ }^{\mathrm{a}}$ Augusto Hauber Gameiro - FMVZ, USP - Orientador

Rubens Nunes

Prof. Dr. FZEA, USP.

Deborah Penteado Martins Dias

Prof ${ }^{a}$. Dr ${ }^{\mathrm{a}}$ CUBM 


\section{DEDICATÓRIA}

À minha mãe, que esteve presente nos momentos mais difíceis pelos quais passei, dando-me força para seguir com coragem e fé de que dias melhores viriam. E eles vieram. 


\section{AGRADECIMENTOS}

Primeiramente, agradeço a Deus por ter nascido em família espírita kardecista, o que me proporcionou adquirir uma fé inabalável em dias melhores e que me possibilita sempre buscar o conhecimento necessário para encontrar a paz e buscar a luz por onde quer que eu vá.

Gostaria de agradecer ao professor doutor Augusto Hauber Gameiro, pela dedicação, amizade e paciência a mim destinados. Sempre mostrando com bom humor o que é exercer um ofício para o qual acredito que tenha um dom. Agradeço a professora doutora Roberta Ariboni Brandi, pela indispensável colaboração dada, o que tornou possível o aperfeiçoamento deste trabalho. Ao professor doutor Rubens Nunes, pelos esclarecimentos que possibilitaram melhor fundamentação do estudo realizado. À Faculdade de Zootecnia e Engenharia de Alimentos, pela oportunidade. Agradeço aos criadores e aos demandantes do Cavalo Brasileiro de Hipismo e outras raças, que colaboraram respondendo os questionários ou formulários. Sem essa colaboração esta pesquisa não poderia ter sido concluída. Agradeço à $\mathrm{ABCCH}$ e seus colaboradores, pelas informações fornecidas. Agradeço a Roseana Grilo, pela amizade, sabedoria e direcionamento essencial para a conclusão deste trabalho. Também agradeço a Idania Blanca Peña Grass, pelo profissionalismo e amizade, essenciais durante o processo de redação deste trabalho. Ao Dr. Rodrigo Dias, pelo profissionalismo e amizade, de extrema importância por todo o período de redação. Agradeço minha tia, Ligia Cibele Dassan Pose, pela paciência, amizade e palavras sábias. Agradeço ao meu padrasto, José Maria Cazonatto, pela paciência, pelos conselhos e pela dedicação durante os anos de convivência. Agradeço à minha mãe, por tudo que já fez e ainda faz por mim, por me apoiar nos momentos mais difíceis, por estar sempre ao meu lado quando necessito e pelo amor incondicional que me dedica. Agradeço a toda a minha família e amigos, por fazerem parte da minha existência, contribuindo para que me tornasse o que sou hoje. 
"Embora ninguém possa voltar atrás e fazer um novo começo, qualquer um pode começar agora e fazer um novo fim" 


\section{RESUMO}

\section{SANTOS, B. E. S. Estudo exploratório do mercado e da produção do Cavalo Brasileiro}

de Hipismo no Estado de São Paulo. 2016. 104 f. Dissertação (Mestrado) - Faculdade de Zootecnia e Engenharia de Alimentos, Universidade de São Paulo, Pirassununga, 2016.

O esporte hípico cresceu significativamente nos últimos anos no Brasil, embora pesquisas sobre o funcionamento e relevância deste setor sejam ainda escassas. Esta pesquisa teve como objetivo realizar estudo exploratório do mercado e da produção de cavalos da raça Brasileiro de Hipismo (BH) no Estado de São Paulo, com o intuito de levantar informações sobre a produção e o mercado dos animais registrados; determinar o custo médio de produção e manutenção dos cavalos da raça; determinar o destino dos cavalos e propor uma tipologia dos usuários do cavalo BH. Para a obtenção dos dados foram aplicados formulários e questionários específicos aos ofertantes e aos demandantes do Cavalo Brasileiro de Hipismo. A pesquisa contemplou seis criadores da raça e 25 demandantes. Verificou-se que, até 2013, havia 8.631 animais registrados, com uma queda significativa a partir de 2011. Os preços dos animais vendidos em leilões realizados pela associação da raça registraram valores que oscilaram entre $\mathrm{R} \$ 18.000$ e $\mathrm{R} \$ 40.000$ e os preços dos animais vendidos pelos criadores variou entre $\mathrm{R} \$ 18.000$ e $\mathrm{R} \$ 80.000$, dependendo da faixa etária dos animais e de outras características. A maioria dos criadores declarou que variações nos custos de produção dos animais não alteram a quantidade produzida e que os proprietários possuem outra fonte de renda. Nas propriedades entrevistadas, as biotecnologias de inseminação artificial e transferência de embriões são frequentemente utilizadas na busca do melhoramento genético dos animais. $\mathrm{O}$ tamanho do plantel dos criadores entrevistados variou entre 12 e 180 animais. Com base nos dados obtidos, chegou-se ao custo médio mensal de manutenção de um animal, por parte dos criadores, de $\mathrm{R} \$ 475,81$. O custo médio mensal de manutenção e treinamento de um animal dispendido pelos demandantes do Cavalo $\mathrm{BH}$ foi de $\mathrm{R} \$ 2.587,80$. A maioria dos animais é alojada em hípicas e é destinada para o uso pessoal, principalmente em competições, em sua maioria nas modalidades do CCE (Concurso Completo de Equitação) e do salto. Dos entrevistados, a maior parte possuía faixa de renda familiar acima de $\mathrm{R} \$ 11.820$, apresentou idade entre 9 e 65 anos; eram amadores e consideravam o cavalo que possuíam como "membro da família". Estudante foi a profissão mais frequente entre os entrevistados. Como motivação para a compra dos animais, o determinante principal foi a qualidade dos mesmos e não o seu preço. $\mathrm{O}$ estudo atendeu aos objetivos propostos e concluiu que o mercado do Cavalo Brasileiro de Hipismo se aproxima da 
concorrência monopolística, na qual a qualidade de cada animal produzido, conseguida por meio da utilização das tecnologias existentes e também com o emprego de mão de obra especializada no treinamento, faz com que cada produtor tenha certo poder de monopólio, no sentido de interferir nos preços de seus produtos.

Palavras-Chave: Equideocultura; Oferta; Demanda; Concorrência Monopolística. 


\begin{abstract}
SANTOS, B. E. S. Exploratory study of the market and production of Brazilian Equestrian Horse in São Paulo state. 2016. 104 f. M. Sc. Dissertation - Faculdade de Zootecnia e Engenharia de Alimentos, Universidade de São Paulo, Pirassununga, 2016.

The equestrian sport has grown significantly in recent years in Brazil, although research on the functioning and importance of this sector are scarce. This research aimed to carry out exploratory study of the market and the production of horses Brazilian Equestrian race (BH) in São Paulo, in order to gather information on the production and marketing of registered animals; determine the average cost of production and maintenance of $\mathrm{BH}$ horses; determine the destination of horses and propose a typology of BH horse users. To obtain the data were applied forms and specific questionnaires to offerors and users of the Brazilian Equestrian Horse. The survey considered six creators of the race and 25 consumers. It was found that by 2013 there were 8.631 registered animals, with a significant drop from 2011. The BH's prices sold at auctions held by the race's association recorded values that ranged from $\mathrm{R} \$ 18.000$ to $\mathrm{R} \$ 40.000$ and the price of animals sold by breeders ranged between $\mathrm{R} \$ 18.000$ and $\mathrm{R} \$ 80.000$, depending on the age of the animals and other factors. Most breeders said that variations in animal production costs do not change the quantity produced and that the owners have another source of income. In interviewed properties, the biotechnologies of artificial insemination and embryo transfer are often used in the search for genetic enhancement. The squad size creators of respondents varied between 12 and 180 animals. Based on the obtained data, the study came to the average monthly cost of maintenance of an animal. The average creator's cost was $\mathrm{R} \$$ 475,81 . The average monthly cost of maintenance and training of one animal spent by the Horse BH's consumers was $\mathrm{R} \$ 2.587 .80$. Most animals are housed in an equestrian centre and is intended for personal use, especially in competitions, mostly in the modalities of eventing and jumping. Of those interviewed, most had family income above $\mathrm{R} \$ 11,820$, presented age between 9 and 65, were amateurs and considered the horse as a "family member". Student was the most common occupation among respondents. As motivation for the purchase of animals, the main determinant was the quality of the animal and not its price. The study met the proposed objectives and concluded that the market of the Brazilian Equestrian Horse seems to be structured as monopolistic competition, in which the quality of each animal produced, achieved using existing technologies and with the use of skilled labour, makes each producer has some monopoly power, to interfere in the prices of their products.
\end{abstract}

Keywords: Horse Breeding; Offer; Demand; Monopolistic Competition. 


\section{LISTA DE ILUSTRAÇÕES}

Figura 1 - Curvas de oferta e demanda por um Bem, ponto de equilíbrio do mercado e preço de equilíbrio de determinado bem.

Figura 2 - Evolução dos registros de cavalos da raça BH no Estado de São Paulo, no Período de 1995 a 2013.

Figura 3 - Evolução de transferências de cavalos da raça BH no Estado de São Paulo, no período de 2000 a 2013.

Figura 4 - Desenho da cadeia da indústria do Cavalo Brasileiro de Hipismo.

Figura 5 - Distribuição da frequência dos entrevistados por faixa de renda familiar (Número de respostas: 18$)$.

Figura 6 - Distribuição da frequência dos entrevistados por faixa de renda (Número de respostas: 21 )

Figura 7 - Distribuição da frequência de profissões observadas nos entrevistados (Número de respondentes: 24 ).

Figura 8 - Distribuição da frequência dos entrevistados por idade (Número de respondentes:

Figura 9 - Percentual de proprietários em função do local onde mantém seus animais (número

de respondentes: 25).

Figura 10 - Distribuição da frequência dos entrevistados por classificação (Número de respondentes: 24).

Figura 11 - Distribuição da frequência $(\%)$ das respostas à pergunta sobre o que representa o cavalo para os respondentes (Número de respostas: 41).

Figura 12 - Distribuição da frequência dos entrevistados por frequência de uso do animal na semana (Número de respostas: 23).

Figura 13 - Distribuição de frequência das respostas sobre os motivadores à prática do

hipismo (Número de respondentes: 25).

Figura 14 - Distribuição da frequência dos entrevistados por algum outro esporte praticado (Número de respostas: 16).

Figura 15 - Distribuição da frequência dos proprietários ou praticantes de hipismo por modalidade equestre (número de respostas: 27).

Figura 16 - Quantidade de animais de posse (Número de respondentes: 25).

Figura 17 - Distribuição da frequência por quantidade de pessoas que utilizam um animal (Número de respostas: 26).

Figura 18 - Percentual por finalidade do uso dos animais pesquisados (Número de respostas: 37)

Figura 19 - Distribuição da frequência dos fatores que motivaram a compra dos animais (Número de respostas: 42).

Figura 20 - Distribuição da frequência dos respondentes por média mensal dispendido em aulas e/ou treinamentos (Número de respondentes: 21).

Figura 21 - Custo médio mensal com estabulagem de um animal (Número de respondentes: 21).

Figura 22 - Distribuição da frequência por média mensal gasta com alimentação (Número de respondentes: 21 ). 
Figura 23 - Distribuição da frequência (\%) de respostas por finalidade da compra do cavalo (Número de respondentes: 24)

Figura 24 - Distribuição percentual das biotecnologias de reprodução utilizada pelos criadores

(Número de respostas: 13)

Figura 25 - Distribuição da frequência de propriedades por custo da transferência de embriões (TE) (Número de respondentes: 5)

Figura 26 - Quantidade de propriedades por quantidade de funcionários empregados (Número de respondentes: 5).

Figura 27 - Percentual de funcionários por cargo na totalidade de funcionários das propriedades (Número de respondentes: 6).

Figura 28 - Base da alimentação dos animais (Número de respostas: 12).

Figura 29 - Quantidade de propriedades por número de ginetes contratados (Número de respondentes: 4$)$

Figura 30 - Custo mensal de cada propriedade com cada ginete contratado (Número de respondentes: 3 )

Figura 31 - Percentual das respostas por modalidade alvo das propriedades criadoras

(Número de respostas: 10) 89

Figura 32 - Os animais participam de competições? (Número de respondentes: 5). 90 


\section{LISTA DE QUADROS}

Quadro 1 - Causas de deslocamento nas curvas de oferta e demanda do Cavalo BH. 36

Quadro 2 - Quantidade de criadores do cavalo BH por cidade no Estado de São Paulo.

Quadro 3 - Renda média domiciliar das classes sociais no Brasil no ano de 2015, em R\$. 59

Quadro 4 - Distribuição da frequência de animais de posse dos respondentes por raça e percentual de cada raça declarada (Número de animais declarados: 177).

Quadro 5 - Percentual de respondentes que mudaria sua compra de acordo com as expectativas vigentes no mercado (Número de respostas: 21 )

Quadro 6 - Tamanho do plantel e quantidade de animais utilizados anualmente na reprodução por cada criador do Brasileiro de Hipismo (Número de respondentes: 6)

Quadro 7 - Custo da dose da IA e custo do trabalho associado por criador (Número de respostas: 7). 79

Quadro 8 - Preços dentro da porteira ou leilões por faixa etária dos potros, em R \$ (Número de respostas: 10)

Quadro 9 - Custo por cargo e média do custo por cargo, em $\mathrm{R} \$$ (Número de respostas: 11).

Quadro 10 - Especificação da assistência recebida, custo e média de custo de tal assistência, em R\$ (Número de respostas: 8)

Quadro 11 - Custo com alimentação por propriedade, R\$ (Número de respondentes: 5). 


\section{LISTA DE SIGLAS}

$\begin{array}{ll}\text { ABCCH } & \text { Associação Brasileira de Criadores do Cavalo de Hipismo } \\ \text { ABEP } & \text { Associação Brasileira de Empresas de Pesquisa } \\ \text { BH } & \text { Brasileiro de Hipismo } \\ \text { CBH } & \text { Confederação Brasileira de Hipismo } \\ \text { CCE } & \text { Concurso Completo de Equitação } \\ \text { COB } & \text { Comitê Olímpico Brasileiro } \\ \text { FEI } & \text { Federação Equestre Internacional } \\ \text { IA } & \text { Inseminação Artificial } \\ \text { NEI } & \text { Nova Economia Institucional } \\ \text { PSI } & \text { Puro Sangue Inglês } \\ \text { TE } & \text { Transferência de Embriões }\end{array}$




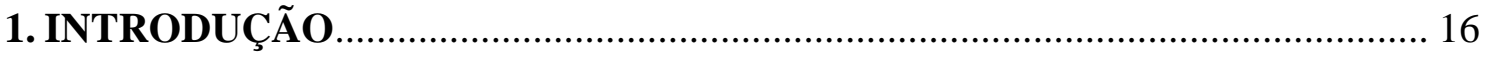

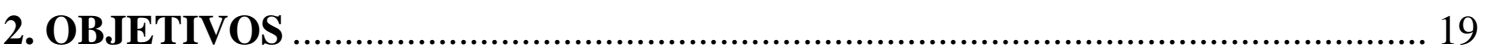

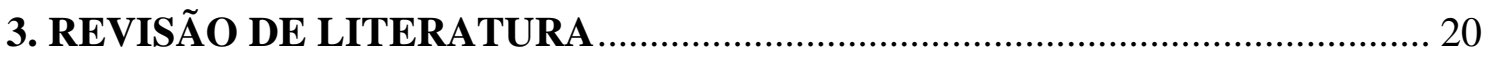

3.1 O HIPISMO ................................................................................................................ 20

3.1.1 A CRIAÇÃO DO CAVALO DE ESPORTE...................................................................23

3.2 MERCADO E TEORIA ECONÔMICA........................................................................ 27

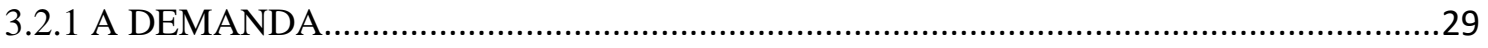

3.2.2 A OFERTA.....................................................................................................

3.3 A CONTRIBUIÇÃO DA NOVA ECONOMIA INSTITUCIONAL (NEI)...................... 37

3.4 ESTUDOS SOBRE MERCADOS, MERCADOS DE CAVALOS E DE SERVIÇOS RELACIONADOS …………….................................................................................................... 40

4. MATERIAIS E MÉTODOS ……………………………………………........ 50

5. RESULTADOS E DISCUSSÃO ……………………………………………. 53

5.1 A DEMANDA …….................................................................................................5 58

5.2 OFERTA …...................................................................................................................................... 76

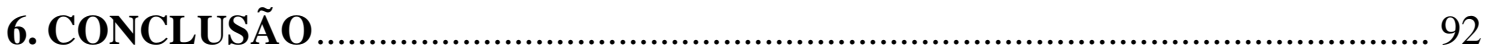

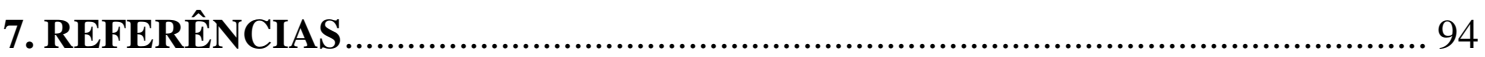

APÊNDICE A: QUESTIONÁRIO DIRECIONADO AOS CRIADORES DO CAVALO

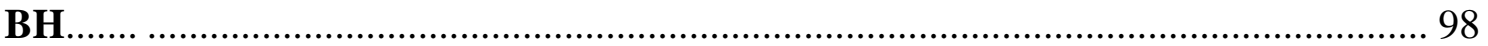

APÊNDICE B: QUESTIONÁRIO DIRECIONADO AOS USUÁRIOS DO CAVALO

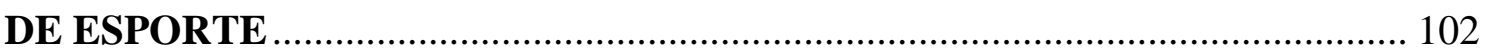




\section{INTRODUÇÃO}

A população de equinos no Brasil é de 5,8 milhões animais, representando o maior rebanho da América Latina e o quarto maior do mundo (FAOSTAT, 2015). Segundo Lima, Shirota e Barros (2006), a indústria do cavalo nacional movimentava naquele ano, cerca de R\$ 7,5 bilhões e gerava 3,2 milhões de empregos diretos e indiretos.

O esporte hípico ganhou evidência no país em 1810, com a inclusão da equitação entre as disciplinas da Academia Real Militar e a realização das provas de corrida. No século seguinte surgiram os primeiros clubes hípicos como a Sociedade Hípica Paulista, em São Paulo, o Club Esportivo de Equitação (hoje Centro Hípico do Exército), no Rio de Janeiro (CONFEDERAÇÃO BRASILEIRA DE HIPISMO, 2010).

A Confederação Brasileira de Hipismo $(\mathrm{CBH})$, órgão máximo do esporte no Brasil, surgiu em 1941 e em 2015 possuía 20 federações filiadas, além da Comissão de Desportos do Exército. A CBH é filiada ao Comitê Olímpico Brasileiro (COB) e à Federação Equestre Internacional (FEI). A CBH regulamenta, promove e fomenta oito esportes hípicos. São eles: o salto, o adestramento, o concurso completo de equitação, o volteio, a atrelagem, rédeas, hipismo para equestre e o enduro. A primeira participação brasileira ocorreu nos Jogos Olímpicos de Londres em 1948, na modalidade de salto (CBH, 2010).

Segundo Lima, Shirota e Barros (2006) cerca de 50 mil pessoas praticavam esportes hípicos no Brasil, nas suas diversas modalidades, sendo cerca de 9 mil filiadas às federações de hipismo. O Estudo do Complexo Agronegócio Cavalo (LIMA; SHIROTA; BARROS, 2006) provavelmente foi o primeiro a levantar dados precisos sobre o setor e é o único estudo brasileiro - de que se tem conhecimento - sobre a relevância econômica do setor.

A criação de cavalos de esporte no país vem se modernizando, utilizando de biotecnologias como a Inseminação Artificial (IA) e Transferência de Embriões (TE) para o melhoramento genético dos animais, com o uso de sêmen importado de garanhões renomados internacionalmente. A utilização da TE também possibilita o emprego de óvulos de éguas renomadas internacionalmente. A diferença entre a qualidade do cavalo importado e a qualidade dos cavalos nacionais tem diminuído cada vez mais e alguns haras brasileiros tiveram, recentemente, três cavalos nacionais listados entre os conjuntos (cavalo e cavaleiro) para a seletiva dos jogos pan-americanos de Toronto, realizados em julho de $2015^{1}$. Os três cavalos são da raça Brasileiro de Hipismo, criados no país. Além disso, alguns dos criadores nacionais

\footnotetext{
${ }^{1}$ NICOTERO, B. Informações disponíveis na rede social da proprietária do Haras Feroleto Antico, 2015.
} 
tiveram cavalos de sua criação convocados para fazerem parte de competições dos Jogos Equestres Mundiais, Jogos Pan-americanos e Jogos Olímpicos, nas modalidades de salto, adestramento e concurso completo de equitação. No concurso completo de equitação (CCE), um dos melhores resultados individuais de um conjunto brasileiro nos Jogos Olímpicos foi do brasileiro Éder Gustavo Baldin Pagoto, da cidade de Pirassununga e sua égua Amazonian Dream, da raça Brasileiro de Hipismo, de criação do Haras Feroleto Antico, localizado na cidade de Pirassununga ${ }^{2}$. Tal fato indica que a qualidade dos cavalos da raça $\mathrm{BH}$ vem sendo aprimorada e ganhando competitividade no mercado.

O cavaleiro Serguei Fofanoff, conhecido como Guega, reside em Ribeirão Preto, onde possui uma escola de equitação, a qual foi visitada pela pesquisadora. Esse centro hípico é polo do concurso completo de equitação (CCE). O Guega já representou o Brasil em competições internacionais do CCE como jogos Pan-americanos e Olímpiadas e utilizou, em algumas destas competições, animais da raça Brasileiro de Hipismo.

$\mathrm{O}$ cavalo da raça $\mathrm{BH}$ é resultado do cruzamento de raças aprovadas no stud book ${ }^{3} \mathrm{da}$ raça, como Sela Francesa, Hannoveriano, Holsteiner, Anglo Árabe, Árabe, Puro Sangue Inglês, Trackener, Westfalen, entre outros. A raça foi lançada no Brasil em 1977, com o objetivo de se criar uma raça essencialmente destinada ao esporte hípico. Os cavalos BH’s são utilizados, principalmente, nas modalidades de salto, adestramento e CCE. Além do mais, a Polícia Militar e montada elegeu a raça Brasileiro de Hipismo, em diversos estados do Brasil, como a raça de escolha para os trabalhos exercidos por estas entidades ${ }^{4}$.

A Associação Brasileira dos Criadores do Cavalo de Hipismo (ABCCH) é responsável pela regulamentação e fomento da raça no país. A $\mathrm{ABCCH}$ aprova os animais a serem registrados na raça, realiza a transferência de propriedade dos animais, tornando-se, assim, intermediária das transações de compra e venda no país. A Associação também promove a raça por meio de eventos como leilões e competições de cavalos BH’s. De acordo com a ABCCH existem, no estado de São Paulo, 1.137 criadores da raça credenciados na associação. A cidade

\footnotetext{
${ }^{2}$ Informação fornecida por Éder Gustavo Baldin Pagoto, em Pirassununga, janeiro de 2012.

${ }^{3} \mathrm{O}$ stud book é o livro de registro que regulamenta uma raça. Nele são registradas as genealogias de todos os animais registrados na raça em questão. O stud book da raça Brasileiro de Hipismo define quais são as raças consideradas de base para a formação do $\mathrm{BH}$. Cruzamento entre cavalos das raças base originam cavalos da raça $\mathrm{BH}$. Cruzamento de cavalos da raça $\mathrm{BH}$ com uma das raças base originam cavalos da raça $\mathrm{BH}$. Cruzamento entre cavalos da raça $\mathrm{BH}$ com cavalos da raça $\mathrm{BH}$, resultam em cavalos da raça $\mathrm{BH}$. O stud book mantém veterinários credenciados à Associação Brasileira dos Criadores do Cavalo de Hipismo $(\mathrm{ABCCH})$, que são responsáveis pela aprovação dos garanhões registrados na raça e das éguas matrizes, depois de exames de morfologia e linhagem dos animais em questão.

40 cavalo da raça foi escolhido por se tratar de um animal que, em geral, possui mais de 1,60 m de cernelha, o que faz com que tenha o porte necessário para o uso na polícia montada.
} 
que mais concentra criadores registrados é a cidade de São Paulo, fato justificado por conta de o registro ser feito em pessoa física, seguida pela cidade de Campinas.

Devido ao fato de haver algumas raças equestres que podem ser utilizadas para os esportes hípicos olímpicos, esta pesquisa propõe o estudo do cavalo da raça Brasileiro de Hipismo $(\mathrm{BH})$. A raça pode ser utilizada nas três principais modalidades olímpicas, que são o salto, o adestramento e o CCE. Por se tratar de uma raça relativamente nova, ela vem se consolidando no Brasil e tornando-se competitiva. Não se conhecem estudos sobre o mercado de cavalos da raça no país, sendo esta pesquisa pioneira nesse sentido.

$\mathrm{O}$ mercado de cavalos da raça $\mathrm{BH}$ possui grande número de ofertantes e demandantes no estado de São Paulo, o que, em princípio, traria a ele indícios de um mercado de concorrência perfeita. Por outro lado, pelo fato de o cavalo ser um bem único, em que cada animal difere dos demais por conta de suas características genéticas, saúde, qualidade, capacidade esportiva, índole, etc., o mercado destes cavalos acaba tendo produtos diferenciados (únicos), em que cada animal ofertado pelo criador difere dos demais, fazendo com que cada criador tenha um certo poder de monopólio. Ao que tudo indica, o mercado de cavalos em questão une as características de mercado competitivo com o monopolístico, sugerindo que a estrutura deste mercado seja similar à estrutura de concorrência monopolística, em que se combinam fatores e características dos dois tipos de organização (VASCONCELLOS, 2001). ${ }^{5}$ Além disso, cada criador também é considerado único, por conta de características como diferenciação pela genética, conhecimento, instalações, etc. Desta maneira, a origem do cavalo funciona como uma marca.

A realização dos jogos olímpicos no Rio de Janeiro, em agosto de 2016, motivou os criadores do cavalo $\mathrm{BH}$ a buscarem ainda mais o melhoramento genético dos animais. Como resultado, dois animais da raça (nascidos no Brasil) estão entre a lista de conjuntos (cavalo e cavaleiro) escalados para integrarem a equipe brasileira. Um na modalidade salto e outro na modalidade do concurso completo de equitação. Os animais observados são de criação dos haras Agromen e Feroleto Antico (ABCCH, 2016).

\footnotetext{
${ }^{5} \mathrm{Na}$ maioria dos leilões, os animais são vendidos na faixa etária de 3 a 4 anos, domados e saltando em liberdade, o que faz com que a individualidade de cada animal se torne mais destacada.
} 


\section{OBJETIVOS}

O presente estudo teve como objetivo geral a realização de uma pesquisa exploratória do mercado e da produção de cavalos da raça BH no Estado de São Paulo.

Os objetivos específicos da pesquisa foram: i) levantar informações sobre o mercado e sobre a produção de cavalos da raça Brasileiro de Hipismo registrados no Estado de São Paulo; ii) determinar o custo médio de produção e manutenção dos cavalos da raça; iii) determinar o principal destino dos cavalos; e iv) propor uma tipologia dos usuários do cavalo $\mathrm{BH}$. 


\section{REVISÃO DE LITERATURA}

\subsection{O HIPISMO}

A Federação Equestre Internacional (FEI) é responsável pela regulamentação e promoção de sete esportes hípicos, além do hipismo paraequestre. Tais esportes são o salto, o adestramento, o concurso completo de equitação (estes três primeiros os principais destinos do cavalo BH), a atrelagem, o enduro, o volteio e rédeas (FEI, 2015). No Brasil, o órgão responsável pela regulamentação, fomento e promoção dos esportes hípicos é a Confederação Brasileira de Hipismo $(\mathrm{CBH})$, que além dos esportes FEI de hipismo, também é responsável pela regulamentação da prova de tambor. O hipismo é o único esporte em que homens e mulheres competem entre si, além de ser um dos únicos em que pode ser praticado por diversas faixas etárias. (CBH, 2015).

O salto tem origem é inglesa, e remonta ao fato de que os ingleses tinham como hábito a prática de passeios e corridas a cavalo nos campos, e também a famosa caça à raposa. Nesta última, os cavaleiros eram acompanhados por cães, que seguiam e capturavam a caça, e acabavam transpondo obstáculos naturais que surgiam no meio do caminho. A modalidade consiste em uma prova contendo um percurso de obstáculos que variam de 0,40 m (escola) a 1,60 m (olímpiadas) de altura, em que são dispostos de 8 a 16 esforços, em que o conjunto (cavalo e cavaleiro) que realizar o percurso com menor número de pontos perdidos por faltas (no caso de queda do obstáculo, desvio ou excesso do tempo concedido) e em menor tempo ganha a competição (CBH, 2012).

A primeira competição oficial de salto foi realizada na Irlanda. A modalidade foi a primeira a integrar os jogos olímpicos, em 1900, sendo, inicialmente, realizadas as provas de salto em altura, salto em distância e percurso por tempo. Em 1912, em Estocolmo, foram realizadas as primeiras competições com um percurso com obstáculos em sequência, invenção do capitão italiano Frederico Caprilli (FREITAS; VIEIRA, 2007).

No salto, o conjunto é testado em uma prova com diversos tipos de obstáculos. São, normalmente, de 12 a 15 esforços, distribuídos em uma área que varia de 700 metros a 900 metros (podem ser picadeiros ao ar livre ou indoor). Dentre os obstáculos que podem fazer parte do percurso estão a vertical, o oxer, a paralela, a tríplice, o muro e o rio. O conjunto percorre o percurso em uma velocidade que varia de acordo com a categoria da competição, e tem pontos descontados se o obstáculo cair, se o cavalo desviar ou refugar o obstáculo e se ocorrer excesso no tempo concedido para a realização do percurso. O conjunto que cometer o menor número de 
faltas e com o menor tempo é o campeão da prova (também pode ser por tempo ideal e tempo concedido). Nos jogos Olímpicos e Pan-americanos as provas são disputadas em três dias consecutivos. No primeiro dia conta-se o resultado para as provas individuais, no segundo dia por equipes e no último dia é realizada a final da competição. Cada equipe de salto conta com quatro conjuntos mais um reserva, sendo que saltam quatro conjuntos de cada país, sendo o pior dos resultados de cada país descartado. No último dia, os melhores 45 conjuntos disputam a final individual e o regulamento permite somente três cavaleiros por país na final. Cada conjunto realiza o percurso duas vezes, quem terminar com o menor número de faltas é o campeão. Se mais de um conjunto terminar os percursos sem nenhuma falta cometida, eles voltam para realizarem um último percurso para o desempate, em que o conjunto que for mais rápido ganha (FREITAS; VIEIRA, 2007).

$\mathrm{O}$ adestramento é a modalidade mais clássica do hipismo. Seus princípios básicos servem como pilares de equitação para as outras disciplinas equestres. A modalidade impõe uma cuidadosa ginástica progressiva e racional, associada a uma preparação mental do cavalo, de forma que nas competições o cavalo deve se mostrar calmo, elástico, descontraído e flexível. Durante a apresentação, o conjunto deve passar ao expectador uma imagem de cavalo confiante, atento e impulsionado, demonstrando perfeito entendimento com seu cavaleiro. As competições são disputadas em diversos níveis de dificuldade e categoria, agrupadas em faixas etárias. Podem ser realizadas a céu aberto ou em picadeiros fechados, em um cercado de 20 por $60 \mathrm{~m}$, piso de areia. Os competidores devem executar, de memória, movimentos perfeitamente definidos pelo regulamento de adestramento, numa sequência pré-estabelecida (reprise) ${ }^{6}$, com movimentos nas três andaduras naturais: passo, trote e galope. A alta qualidade da apresentação é demonstrada pela regularidade das andaduras, pela leveza e facilidade dos movimentos. $\mathrm{O}$ grau de exatidão e correção na execução dos movimentos é avaliado por três a cinco juízes, posicionados ao longo do picadeiro. Os árbitros julgam os movimentos dos concorrentes, atribuindo notas de 0 a 10, sendo o vencedor aquele que obtiver o maior percentual, resultante do somatório de todos os graus atribuídos pelos juízes (CBH, 2012).

Já o concurso completo de equitação (CCE) se trata do "triátlon do hipismo". A competição é dividida em três provas: o adestramento, o cross country e o salto, que são realizadas em dias consecutivos, sendo a prova realizada em três dias. O esporte é importante

\footnotetext{
${ }^{6}$ Reprise: sequência pré-estabelecida de movimentos que o conjunto deve realizar durante a competição. O picadeiro possui letras para sua marcação, e nas reprises são estabelecidos os movimentos que o conjunto (cavalo e cavaleiro) deve executar em cada letra de marcação. Na reprise o conjunto realiza uma coreografia préestabelecida nas três andaduras (passo, trote e galope). Os movimentos formam figuras no picadeiro como círculos, semicírculos, piruetas e diagonais.
} 
exposição de capacidade do conjunto, que se mostra capaz de competir em três distintas modalidades de esporte equestre em curto período de tempo, o que exige preparo técnico e físico. No primeiro dia é realizada a prova de adestramento. No segundo, a prova de o cross country, em que o conjunto percorre um percurso externo, com obstáculos rústicos inspirados em obstáculos naturais e do campo, como mesas, troncos, buracos, piscinas, entre outros, com alto grau de dificuldade. No último dia ocorre a prova de salto, sendo que o objetivo da prova é mostrar que após a exigente prova do cross country o animal continua com energia, resistência e obediência ao comando do cavaleiro ( $\mathrm{CBH}, 2012)$.

O CCE foi introduzido no Brasil por integrantes de uma missão francesa que chegou ao país para transmitir ensinamentos equestres aos militares. Durante cerca de meio século a modalidade foi desenvolvida e praticada quase exclusivamente por militares. O primeiro campeonato de CCE foi disputado em 1922, com duração de quatro dias. Em 1941 as provas passaram a ser realizadas de acordo com o regulamento da FEI. Sete anos depois foi registrada a primeira participação brasileira de equipes nos jogos Olímpicos. Nos últimos vinte anos, a modalidade teve grande progresso no país, tendo trazidos bons resultados internacionais em competições, entre eles a medalha de ouro nos jogos Pan-americanos de 1995 e a de prata em 1999 (FREITAS; VIEIRA, 2007).

As competições de CCE são classificadas de 1 até 4 estrelas. Nas provas de 1 estrela $\left(1^{*}\right)$, os obstáculos das provas de cross country e salto medem 1,15 metros. Na categoria de duas estrelas $\left(2^{*}\right)$ os obstáculos medem 1,20 metros. Na categoria de 3 estrelas $\left(3^{*}\right)$ medem 1,30 e na categoria de 4 estrelas ( $\left.4^{*}\right)$ medem 1,40. Além da mudança na altura dos obstáculos, o grau de dificuldade dos movimentos a serem realizados pelos conjuntos durante a execução das reprises de adestramento se tornam mais elevados. Desta maneira, as reprises da categoria de $1^{*}$ são mais simples que a da $2^{*}$, que são mais simples que da $3^{*}$ e que são mais simples do que a categoria de $4^{*}$. Os campeonatos brasileiros têm competições que variam entre uma a três estrelas. Os jogos Pan-americanos têm nível de duas estrelas e a Olímpiadas e competições famosas como Badminton HorseTrials e Burghley HorseTrials (realizados na Inglaterra) têm nível de quatro estrelas.

Existem algumas raças de cavalos que podem ser utilizadas para as modalidades dos esportes em questão (adestramento, salto e concurso completo de equitação). No adestramento, as raças mais utilizadas são: Andaluz, Puro Sangue Lusitano, Hanoveriano, Holsteiner, Oldenburg, Trakener e o BH. No salto, as raças mais utilizadas são o Sela Francesa, Sela Holandesa, Hannoveriano, BavarianWarmblood, Baden Wuttenburg, Belgian Warmblood, Danish Warmblood, Finnish Warmblood, Holsteiner, German Warmblood, Norwegian 
Warmblood, Oldenburgo, Cavalo de Esporte da Grã-Bretanha, Cavalo de Esporte da Irlanda, Cavalo de Esporte Húngaro, Cavalo de Sela Italiana, Swedish Warmblood, Trakener, Westfalen e BH. No CCE, podem ser utilizadas as mesmas raças que as utilizadas no salto, além do Puro Sangue Inglês e Anglo-Árabe.

O cavalo da raça Brasileiro de Hipismo (BH) foi criado no país por meio do cruzamento de algumas raças importadas aprovadas no stud book da associação que regulamenta a raça. São elas: Árabe, Anglo Árabe, Andaluz, Anglo Europeu, Cavalo de Sela Americano, American Warmblood, Bavariano, Bayern, Hannoveriano, Hessen, Holsteiner, Mecklenburg, Anglo Normando, Oldenburgo, Puro Sangue Inglês, Rheiland, Sachsen-Anhalt, Sela Argentina, Sela Belga, Sela Dinamarquesa, Sela Francesa, Sela Holandesa, Sela Irlandesa, Sela Italiana, Sela Luxemburguense, Sela Mexicana, Sela Norueguesa, Sela Polonês, Sela Suíça, Sela Sueca, Sela Uruguaia, Trackener, Westfalen, Wurttenberg, Zanguersheide, Zwebruckene e Friesian. O cruzamento entre cavalos das raças base, ou de cavalo BH com cavalo de uma das raças consideradas base da raça, ou cruzamento do cavalo $\mathrm{BH}$ com outro cavalo $\mathrm{BH}$ resulta em cavalo da raça $\mathrm{BH}(\mathrm{ABCCH}, 2014)$.

\subsubsection{A CRIAÇÃO DO CAVALO DE ESPORTE}

A Associação Brasileira dos Criadores do Cavalo de Hipismo (ABCCH), que regulamenta a criação do cavalo $\mathrm{BH}$ permite que sejam utilizadas as biotecnologias de reprodução de TE e IA, além da monta natural ${ }^{7}$. O cavalo foi o primeiro animal em que a biotecnologia de IA foi utilizada. Esta técnica utiliza manequins para a coleta do sêmen do garanhão, que é posteriormente utilizado para inseminar a égua. O sêmen pode ser utilizado a fresco ou congelado. A qualidade do sêmen, quando congelado, varia de acordo com cada garanhão, e geralmente não é relacionada com a fertilidade do mesmo. Apesar de o cavalo ter sido o primeiro animal doméstico de grande porte no qual a IA foi utilizada, os equinos foram os últimos animais nos quais a TE foi praticada (ALLEN, 2005).

A IA é considerada a mais importante técnica utilizada na reprodução, possibilitando o melhoramento genético de animais, com a utilização de sêmen fresco ou congelado de animais renomados mundialmente. A técnica inclui o manejo, a avaliação e a preservação do sêmen para posterior inseminação (FOOTE, 2002). A TE tem sido utilizada na produção de equinos para aumento da quantidade de animais gerados anualmente (CAIADO et al., 2007). A TE

\footnotetext{
${ }^{7}$ FERREIRA, R. Informações sobre a criação de cavalos da raça Brasileiro de Hipismo. Mensagem recebida por rica.ferreira7@gmail.com em 11 ago. 2015.
} 
utiliza éguas receptoras do embrião produzido in vivo ou in vitro. (SCOTT et al., 2001) Depois de pronto o embrião, o mesmo é transferido para uma égua receptora para que ocorra a continuidade da gestação.

Na criação do cavalo de esporte alguns fatores são levados em consideração. Um estudo realizado em 2004 por Aldridge, Koenen e Phillipsson identifica quais são estes fatores. De acordo com o estudo, os fatores que mais influenciam no objetivo de dezenove raças europeias diferentes eram a conformação, o salto, o adestramento, a andadura, o comportamento, o concurso completo de equitação e a saúde do animal. $\mathrm{O}$ estudo afirma que uma das dificuldades na criação de cavalos para o esporte é que as peculiaridades do animal são definidas somente de maneira geral. E isto se reflete pelo fato de que muitas das características do cavalo de esporte não serem de fácil mensuração. Os autores afirmam, ainda, que muitos dos criadores desejam criar um cavalo de bom desempenho, sem predefinir se o mesmo será destinado ao salto, ao adestramento, ou ao concurso completo de equitação. Além disso, os criadores não definem qual será o nível de competição ao qual o animal será destinado: amador, nacional ou internacional. A conclusão do estudo é que o principal objetivo das criações das diversas raças europeias é manter as características e peculiaridades das raças, além de conseguir bons padrões dos fatores citados acima.

As diferentes características desejadas pelos criadores das diferentes raças de cavalos na Europa, de acordo com Aldridge, Koenen e Phillipsson (2004), fazem com que a seleção genética seja mais específica, buscando aperfeiçoar a raça cada vez mais. Os autores afirmam que muitos dos criadores de equinos o fazem por lazer, o que faz com que operem com nenhum ou muito baixo lucro, o que pode levar ao questionamento se a criação é eficiente economicamente. A criação de equinos para esporte deve ser feita de acordo com as expectativas de mercado, em proporção à população de cavalos que é vendida no mercado. Além disso, torna-se necessário que se produza um cavalo de esporte a um preço adequado.

O passaporte ${ }^{8}$ é documento necessário para as transações de compra e venda do animal, tanto nacionalmente como internacionalmente. As transferências e registros de seus donos também são registradas no documento. Não existe estudo no Brasil de que se tenha conhecimento, que aponte qual a porcentagem real de animais que possui o documento. Porém, como citam Henessy e Quinn (2006), na Irlanda, país que tem o mercado de cavalos de esporte mais desenvolvido e vistoriado que o Brasil, ainda existe grande porcentagem de animais que

\footnotetext{
${ }^{8}$ O passaporte é a identidade do animal. Possui a resenha do cavalo. É necessário em casos em que o equino participa de competições oficiais.
} 
não possuem o documento. Os autores defendem a microchipagem ${ }^{9}$ de todos os cavalos registrados na raça irlandesa, a fim de que haja maior controle, tanto de identificação, quanto de origem $^{10}$.

Ainda de acordo com Henessy e Quinn (2006), a criação do cavalo de esporte irlandês é destinada tanto para o esporte, quanto para o lazer, sendo que, por conta disso, a administração dos haras criadores deve ser direcionada para que se possa tirar proveito das duas situações. Segundo o estudo, os ambientes em que as estruturas de criação, lazer e esporte estão operando está mudando rapidamente, sendo que os competidores e os stud books estão se tornando cada vez mais profissionais em seu planejamento, administração e estrutura e é necessário que a indústria de cavalo de hipismo faça o mesmo. Para que isso aconteça, é necessário que haja o desenvolvimento efetivo e eficiente da administração e das estruturas de suporte, combinados com objetivos e regras definidos, sustentados pela transparência, prestação de contas, clara e racional tomada de decisões, comunicação eficaz, marketing e promoção focados, educação adequada e estruturas de formação.

O sucesso da indústria de cavalos de esporte depende de administração adequada, liderança com padrões profissionais de gestão. Os princípios de boa governança incluem conformidade, desempenho relacionado a política alvo, eficácia operacional, relacionamentos eficazes entre a diretoria e coesão, facilitando a diversidade. A administração da indústria equina precisa ser feita sem que haja interesses pessoais inclusos. Ainda de acordo com Henessy e Quinn (2006), claras definições de regras e responsabilidades são necessárias para todas as posições (pagas e voluntárias), incluindo o conselho, membros do comitê, time de administração, competidores e participantes. Códigos de conduta devem ser desenvolvidos sob os quais eles devem operar e participar. Planos de estratégia são fundamentais para o futuro. Se não há planejamento, não há direção identificada para o futuro.

A indústria deve investir no desenvolvimento de um sistema de tecnologia de informação, infraestrutura que facilitaria o desenvolvimento de um sistema de administração de dados da indústria de cavalo de esporte, incorporando o banco de dados da indústria. Isto, ainda de acordo com os autores, deve ser combinado com a facilitação no acesso à softwares adequados para aumentar a eficiência e capacidade de cada criador, tal como programa de

\footnotetext{
${ }^{9}$ O microchip é a maneira mais segura de identificar os animais e nele constam informações como data de nascimento e raça. A ABCCH tornou obrigatória a microchipagem de todos os animais registrados na associação. ${ }^{10}$ No Brasil, a Confederação Brasileira de Hipismo tornou obrigatória a detenção de passaporte para animais que participem de competições nacionais regulamentadas pelo órgão, que constem no calendário oficial. O documento deve ser constantemente atualizado. A Federação Equestre Internacional também determina que os animais que participem de competições por ela regulamentadas possuam o passaporte.
} 
pontuação e programas de gerenciamento de dados. Além disso, os autores afirmam ser essencial o investimento no treinamento no pessoal de apoio da indústria, tanto os profissionais pagos quanto os voluntários (HENESSY; QUINN, 2006). 


\subsection{MERCADO E TEORIA ECONÔMICA}

Em um mercado caracterizado por concorrência monopolística existe grande número de empresas produzindo determinado bem ou serviço. Contudo, cada empresa oferta um produto diferenciado, no que se refere à qualidade e padrão vigente. Ao mesmo tempo, estes produtos são considerados substitutos próximos. Cada empresa exerce certo poder de influência no preço praticado no mercado. O consumidor, por sua vez, tem opção de escolha, de acordo com sua preferência. Não existem barreiras significativas à entrada de novos concorrentes nesse mercado, fazendo com que no longo prazo, exista a tendência de se auferirem lucros normais (VASCONCELLOS, 2001).

De acordo com Nordhaus e Saumuelson (2004), um mercado estruturado como concorrência monopolística é parecido com mercado que funciona como concorrência perfeita, por haver grande número de empresas. O que faz com que esta estrutura difira da concorrência perfeita é o fato de os produtos vendidos por estas empresas não serem idênticos. No caso de cavalos, nenhum animal é idêntico ao outro, cada um é único, por se tratar de um indivíduo com atributos peculiares. Esta característica, que traz a diferenciação de cada animal - fazendo com que o ofertante tenha certo poder de monopólio no mercado -, somada à existência de grande número de ofertantes e demandantes no mercado - o que traz fatores de concorrência perfeita -, faz com que o mesmo possa ser considerado como de concorrência monopolística.

Apesar de o número de empresas existentes no mercado ser grande, cada empresa diferencia seu produto de tal forma que acaba criando um segmento próprio de mercado, que a empresa domina e procura manter. O consumidor encontra facilmente substitutos no mercado, e por conta disso, não ocorre a caracterização essencial do monopólio puro. Determinada diferenciação significa certo poder de monopólio e a característica de concorrência se dá pelo fato de haverem bens substitutos próximos. Como principais características, os mercados estruturados como concorrência monopolísticas apresentam: competição entre as empresas, diferenciação de produtos, substitutibilidade entre os produtos, preço-prêmio (a capacidade de cada concorrente influenciar o preço de mercado do bem depende do grau de diferenciação deste bem no mercado) e baixas barreiras à entrada no mercado em questão (ROSSETTI, 2003).

De acordo com Krugman e Wells (2007), em geral o número de pessoas que quer comprar determinado bem ou serviço depende de seu preço. Quanto mais alto for o preço de determinado bem, menor será o número de pessoas que estarão dispostas a comprar este bem ou o serviço. Da mesma maneira, quanto mais baixo for o preço deste determinado bem, maior será o número de pessoas dispostas a comprar este bem ou serviço. 
$\mathrm{Na}$ análise econômica, de acordo com Varian (2006), dois princípios básicos são utilizados na determinação da oferta e da demanda. São eles o princípio da otimização e o princípio do equilíbrio. O primeiro princípio, citado pelo autor, consiste no fato de que os indivíduos sempre tentarem escolher o melhor padrão de consumo ao seu alcance, de acordo com a sua restrição orçamentária. Em outras palavras, os agentes do mercado escolhem uma cesta de bens e serviços que lhes proporcione uma maior utilidade (satisfação), dentro de suas condições financeiras. Já o segundo pressuposto, de acordo com o autor, assume que os preços de mercado se ajustam de tal maneira de modo que o total demandado de determinado bem ou serviço seja igual ao total ofertado deste mesmo bem ou serviço. Considerando o mercado de determinado bem ou serviço, alcança-se o ponto de equilíbrio quando o total ofertado deste bem se iguala ao total demandado por este mesmo bem, sendo estabelecido, assim, o preço de mercado deste bem ou serviço.

Ainda de acordo com Varian (2006), o primeiro princípio é quase tautológico. Uma vez que, se as pessoas têm o poder de escolha, é razoável trabalhar com a hipótese de que escolherão o que querem e não o que não querem para si. Já o segundo pressuposto, afirma ele, consiste no fato de que, no caso em que as quantidades demandadas e ofertadas de determinado bem ou serviço não são equivalentes, pode se tratar de um sinal de que alguma mudança esteja ocorrendo neste determinado mercado, lembrando que o pressuposto do equilíbrio parte do princípio de que os agentes da economia ajam de maneira coerente.

Neste contexto, faz-se importante citar a relevância dos trade-offs. De acordo com Pindyck e Rubinfeld (2007), os consumidores e empresas têm que lidar com trade-offs na escolha de melhor alocação de seus recursos. No caso dos consumidores, os mesmos têm sua renda limitada, e, por conta disso, necessitam verificar de que maneira poderão alocar tais recursos de maneira mais eficiente: quais bens e serviços serão consumidos em detrimento de outros bens e qual parcela de sua renda será poupada para o futuro. No que se refere às empresas, afirmam os autores que as mesmas encontram limitações no que se refere ao que podem produzir e aos recursos disponíveis para o emprego da produção (capital, insumos, tecnologia). As empresas têm de escolher qual será a melhor combinação destes fatores para determinar qual será a sua produção. Todos esses trade-offs se baseiam nos preços que consumidores e empresas encontram no mercado. Em uma economia de mercado competitivo, os preços são determinados através da interação dos consumidores e empresas.

Auler e Werlang (1993) afirmam que em uma economia existe o risco de uma transação, que pode ser definido como sendo os eventos exógenos que afetam o retorno dos ativos escolhidos. Os agentes da economia em questão negociam os diversos ativos disponíveis com 
o intuito de reduzir os riscos inerentes destes ativos, de modo que seus preços são determinados, também, em função destes riscos. No caso da compra do cavalo para investimento, existe a oportunidade de arbitragem deste ativo, se o investidor adquire o animal pelo preço equivalente a outro ativo alternativo.

Segundo Assaf Neto (2009) a arbitragem trata-se de uma operação na qual o investidor tira proveito de um desequilíbrio nos preços dos ativos em diferentes mercados. Esta operação permite que o agente adquira certo ativo em um determinado mercado, a um preço, e vende o mesmo ativo a um preço superior, em outro mercado. A operação de arbitragem, neste caso, consiste em adquirir um ativo no mercado futuro e vende-la no mercado a vista. No caso do cavalo, como o mesmo se desenvolve com o passar dos anos (por conta do seu treinamento, histórico em competições), a compra de um animal jovem para vendê-lo após o amadurecimento e desenvolvimento do animal pode ser considerada, de certa forma, uma operação de arbitragem.

\subsubsection{A DEMANDA}

A demanda por um bem ou serviço é a quantidade deste bem ou serviço que os consumidores estão dispostos a comprar, a um certo preço de mercado. A curva de demanda é aquela que demonstra a relação entre a quantidade demandada de determinado bem e seu preço. Os economistas trabalham com o chamado preço de reserva. Tal preço é representado pelo máximo que o indivíduo está disposto a pagar pelo bem em questão. A curva de demanda tem seu início (intercepto) exatamente no preço de reserva do bem. Sua inclinação, via de regra, é negativa, uma vez que, quanto menor o preço do bem, maior o número de pessoas dispostas a comprar tal bem (VARIAN, 2006).

A curva de demanda por um bem - forma gráfica de quanto os consumidores estão dispostos a comprar de determinado bem ou serviço a determinados preços - pode se deslocar por conta de mudanças nos preços de bens relacionados (substitutos ou concorrentes), mudanças de renda, mudanças de gosto e mudanças nas expectativas (Krugman e Wells, 2007). Um deslocamento na curva de demanda para a direita sugere que houve aumento na procura por determinado bem, provocada, por exemplo, por aumento renda do consumidor, permitindo que este possa consumir mais aos mesmos preços. Quando ocorre deslocamento da curva de demanda para a esquerda, a quantidade demandada de determinado bem ou serviço cai. Tal deslocamento pode ser justificado, por exemplo, por uma mudança no gosto do consumidor, que passa a preferir outro bem em detrimento ao primeiro. 
Mankiw (2010) afirma que os bens complementares também causam deslocamentos na curva da demanda. Os bens complementares são bens que são usados em conjunto com outros bens. $\mathrm{O}$ uso de determinado bem faz com que seja necessária a utilização de outros bens como complemento. No caso do hipismo, a sela é complementar a barrigueira, que também é complementar ao baixeiro e também ao protetor de rim do animal. São bens que precisam uns dos outros para serem utilizados. A sela tem que ser, necessariamente, presa pela barrigueira, sendo que entre a sela e o lombo do animal, necessariamente se utiliza o baixeiro e o protetor de rim. Mankiw (2010) afirma que estes tipos de bens são correlacionados, sendo que tal correlação pode ser de dois tipos: a correlação de substituição e a correlação de complementação. No caso da sela e da barrigueira são os bens complementares. No caso da correlação de substituição, quando o uso de um bem é substituído pelo uso de outro, cita-se como exemplo, o uso de uma rédea simples ou rédea dupla (no caso de um freio bridão, por exemplo).

Os bens substitutos são bens que podem ser consumidos em detrimento de outro bem, sem afetar a utilidade do consumidor - medida pela curva de indiferença, que relaciona a cesta de consumo preferida de acordo com os preços vigentes no mercado. É a combinação de consumo que torna o consumidor mais satisfeito, de acordo com a sua restrição orçamentária.

O ponto ótimo de consumo, de acordo com Varian (2006), ocorre no ponto de intersecção entre a curva de indiferença do demandante e a reta de restrição orçamentária, que representa a sua renda. Um exemplo clássico de bens substitutos é a manteiga e a margarina. Caso seja necessário alterar o consumo passando da manteiga para a margarina por conta do preço, o consumidor quase não sentirá diferença por conta da mudança.

No caso de cavalos de esporte cita-se duas possibilidades. A primeira se dá no cenário do esporte amador. Quando o usuário do cavalo pratica o hipismo por lazer e ocorre mudança nos preços substitutos ao hipismo - no caso outras formas de lazer ou esporte - a demanda pelo bem cavalo pode se alterar. Para melhor se entender essa relação, pode-se usar o conceito de preços relativos. Como outras formas de lazer seriam substitutas à pratica de esporte e, consequentemente, a demanda pelo cavalo de esporte, é necessária a análise dos preços relativos. O preço relativo, como o próprio nome diz, relaciona o preço de determinado bem com o de outro. Neste caso, relaciona o preço do cavalo de esporte com o preço de outras atividades de lazer - podem-se incluir aí várias atividades como viagens, cinema, teatro e até mesmo a prática de outros esportes.

Se o preço relativo do cavalo de esporte se tornar mais alto, haverá tendência de migração do consumo do bem cavalo de esporte para as outras formas de lazer. O usuário do 
cavalo trocará o uso do cavalo de hipismo por outras formas de lazer, de modo a otimizar sua utilidade de acordo com a sua restrição orçamentária e novos preços de mercado, de maneira que a sua utilidade se mantenha praticamente inalterada com a mudança. Neste caso, haverá queda no consumo do bem cavalo de hipismo. Caso o preço de outras raças se torne mais baixo, também poderá haver queda no consumo do cavalo Brasileiro de Hipismo, uma vez o preço de outras raças que possam ser utilizadas para a prática do esporte se torna relativamente mais baixo.

O oposto também ocorre. Caso o preço relativo do cavalo se torne mais baixo em relação às outras formas de lazer preferidas pelo usuário do cavalo - um ou mais bens de lazer consumidos pelo indivíduo tenha seu preço alterado para cima -, a demanda por cavalo de esporte ou a prática de hipismo poderá aumentar. Já no caso da prática do esporte profissional, a alteração do preço relativo do bem cavalo de hipismo não deve alterar significativamente o uso do bem, uma vez que neste caso não há bem substituto perfeito para o mesmo.

Pode-se analisar, também, a alteração na demanda por conta de mudança na renda do consumidor. A renda do consumidor é um dos mais importantes fatores que determinam a demanda por um bem. Alterações na renda do consumidor fazem com que haja mudança na demanda de bens e serviços. A elasticidade-preço da demanda é a relação existente entre as modificações relativas (ou percentuais) observadas nas quantidades demandadas, decorrentes de alterações relativas nos preços. Os produtos cuja a procura reage unitariamente à renda, apresentando elasticidade-renda próxima de 1 são definidos como bens normais. Os bens que apresentam altas variações de procura em resposta variações de renda são chamados de bens superiores. Os bens inferiores são aqueles que a procura cai em consequência de aumento na renda do consumidor (ROSSETTI, 2003). Acredita-se que o bem cavalo de hipismo seja um bem normal. Quando ocorre aumento na renda, o consumo por este bem aumenta proporcionalmente.

Outro fator que altera a demanda por um bem, como dito anteriormente, é a mudança no gosto do consumidor. Mais uma vez, como ocorre com o preço relativo de bens substitutos, a mudança no gosto altera a demanda dos usuários de cavalos que praticam o esporte por lazer. Ocorre que o gosto do agente pode se alterar. Pode acontecer de ele simplesmente passar a não gostar mais de praticar o esporte ou passar a preferir outro tipo de lazer em detrimento do hipismo. Neste caso, a demanda pelo esporte e pelo cavalo se retrairia. Da mesma maneira, caso o usuário do cavalo passe a gostar mais do esporte em relação às outras formas de lazer por ele praticadas ou se houver alteração quanto a preferência de raça, o seu consumo pelo serviço hipismo ou pelo bem cavalo vai aumentar, gerando aumento na demanda. 
Por fim, de acordo com Mankiw (2010), mudanças nas expectativas causam alterações na curva de demanda do bem. Caso o consumidor tenha expectativa de obter, por exemplo, renda maior no futuro, o mesmo passará a consumir mais no presente, já visando seu aumento de renda futuro. No caso de expectativa de que o preço de determinado bem caia no futuro, o consumidor deixa de consumi-lo no presente para poder aproveitar seu preço mais baixo no futuro. Assim, caso haja expectativa de que a renda do consumidor vá aumentar no futuro, provavelmente a demanda pelo bem cavalo aumentará no presente. $\mathrm{O}$ inverso também ocorre, uma vez que, caso haja expectativa de que a renda do consumidor vá diminuir no futuro, a demanda pelo cavalo de esporte cairá no presente.

\subsubsection{A OFERTA}

A oferta de determinado bem ou serviço é a quantidade disponibilizada no mercado deste determinado bem ou serviço. É a quantidade ofertada por parte dos vendedores, a um determinado preço de mercado. A curva de oferta mostra a relação entre a quantidade ofertada de determinado bem ou serviço e o preço do mesmo. Tem a inclinação positiva e seu intercepto também representa o preço mínimo o qual os ofertantes estão dispostos a vender tal bem. Quanto menor o preço do bem, menor a quantidade ofertada, e quanto maior o seu preço, maior a quantidade ofertada do bem (VARIAN, 2006). No caso do cavalo da raça BH, os ofertantes são, principalmente, os criadores.

Um insumo é qualquer bem utilizado para elaborar outro bem (VARIAN, 2006). Da mesma maneira que os bens possuem preço, os insumos também o têm. A quantidade ofertada de um insumo depende, portanto, do preço pago pelo mesmo, no mercado. A curva de oferta do bem a ser produzido com um insumo é deslocada por razão de mudança no preço dos insumos, mudanças na tecnologia e mudanças nas expectativas. Um deslocamento na curva de oferta de um bem ou serviço pode representar um salto na quantidade produzida por este bem ou uma queda na produção do mesmo. Tais deslocamentos da curva representam mudança na quantidade geral produzida em determinado mercado.

Quando a curva de oferta se desloca para a direita, ocorre um aumento geral da oferta que pode ser justificado, por exemplo, pela descoberta ou emprego de uma nova tecnologia, que possibilite ganho de escala. Já quando a curva de oferta se desloca para a esquerda, ocorre uma queda no total produzido de determinado bem, queda esta que pode ser resultante, por exemplo, de um aumento no preço dos insumos (KRUGMAN; WELLS, 2007). 
Sendo assim, caso haja aumento no preço dos insumos ou serviços - mão-de-obra, concentrado, feno, suplementos, vacinas, produtos veterinários, maravalha, ferrageamento, sêmen, entre outros - a criação do cavalo tem um custo mais elevado, o que faz com que os produtores estejam menos dispostos a produzir ao mesmo preço de mercado, fazendo com que a oferta de cavalos diminua (deslocamento da curva de demanda para a esquerda). Caso ocorra o contrário, ou seja, caso os preços dos insumos se tornem mais baixos, a criação do cavalo se tornará mais econômica, fazendo, em teoria, com que haja aumento na sua produção e oferta (deslocamento da curva da demanda para a direita).

Com relação a mudanças na tecnologia, Krugman e Wells (2007) afirmam que os economistas se referem à tecnologia como o modo de produção empregado: todo o conhecimento adquirido no modo de produção do bem. Dessa maneira, quando surge uma nova tecnologia, que possibilite um ganho na quantidade do produto ofertado, pode ocorrer aumento na produção deste bem, aos mesmos preços praticados originalmente.

Neste sentido, no caso de criação de equinos, algumas tecnologias podem ser utilizadas. A evolução tecnológica pode ser definida como um modo de produção que faça com que a produção aumente, utilizando-se, por exemplo, menos mão de obra empregada na produção de determinado bem, menos insumos utilizados para a produção da mesma quantidade de produto, ou uma reprodução mais rápida e que garanta melhor qualidade da cria. O emprego de novas tecnologias faz com que exista um ganho de escala. Com os mesmos fatores de produção utilizados anteriormente, mas com uma nova tecnologia, pode-se produzir mais de determinado bem a um custo unitário inferior.

Existem as tecnologias para o bem-estar do animal e seu treinamento como os exercitadores circulares, esteiras, piscinas, hidroesteiras, raio infravermelho, entre outros, que são mais encontrados em criadores com porte médio ou grande. Estes tipos de equipamentos possibilitam maior segurança no treinamento dos animais, possibilitando o desenvolvimento de condicionamento físico associado à segurança, evitando possíveis lesões.

A tecnologia utilizada na reprodução animal também é de suma importância. As técnicas de transferência de embrião e inseminação artificial possibilitam melhoramento genético, uma vez que os haras criadores podem comprar sêmen de garanhões renomados mundialmente ou óvulos de éguas famosas, fazendo com que a raça se torne cada vez mais competitiva. Além do mais, o bem-estar trazido para as éguas com tais técnicas pode ser significativo, uma vez que alguns garanhões podem ser agressivos, podendo morder e dar manotadas ("coice" com a pata dianteira). Sendo assim, as tecnologias utilizadas na reprodução podem conferir maior bem-estar aos animais. 
Além disso, a tecnologia utilizada na nutrição do animal influencia a saúde e oferta do mesmo. Visto que cada vez mais são empregadas tecnologias avançadas na produção de ração e suplementos dos animais, os mesmos passam a ter melhor nutrição e suplementação balanceadas, de acordo com o nível de esforço e com a época de desenvolvimento. As indústrias de rações para equinos elaboram diferentes tipos de concentrados e suplementos, de acordo com a necessidade. Existem as rações para potros, para éguas gestantes, animais atletas, etc., que possibilitam uma nutrição mais personalizada de cavalo para cavalo, contribuindo assim para seu desenvolvimento em cada fase de sua vida. Todas estas tecnologias permitem melhor condicionamento, bem-estar e tratamento do cavalo atleta.

Mankyw (2005) afirma que as expectativas também causam alteração na curva de oferta. Se, por exemplo, a empresa tem a expectativa de que o preço do seu produto subirá no futuro, ela estocará parte de seu produto hoje, ofertando menos, para que possa no futuro vender seu produto a um preço mais alto. Desta maneira, se existe a expectativa de que o preço do cavalo suba no futuro, a tendência é de que os criadores do animal passem a ofertar menos animais no presente, para que no futuro tenham mais cavalos disponíveis para a venda, com o preço de mercado mais elevado. Isto pode ocorrer no caso dos leilões, em que o proprietário pode decidir levar menos animais para determinado evento, com a expectativa de que no futuro o preço por estes mesmos animais seja mais alto. No que se refere ao aumento de produção, pelo fato de o cavalo ser um bem que demora para ser disponibilizado no mercado, sendo o tempo de gestação de uma égua de aproximadamente um ano, as expectativas podem atuar de maneira um pouco diferente, pois além do tempo para o nascimento do potro, um haras trabalha com a venda de potros, mas, com maior frequência, trabalha com a venda de cavalos com idade entre 1 e 7 anos, domados ou iniciados ao menos no salto em liberdade, o que faz com que o tempo para se ter um produto final seja grande, podendo assim, ter certa influência na decisão de aumentar ou não o seu plantel.

No equilíbrio de mercado, as curvas de oferta e demanda se cruzam no ponto ótimo, onde é estabelecido o preço de equilíbrio de determinado bem. O preço de mercado é definido exatamente na intersecção das curvas de demanda e oferta do bem. Pode-se verificar as curvas de oferta e demanda de um determinado bem, bem como o ponto de equilíbrio deste mercado e o preço de mercado do bem em questão na figura 1. 
Figura 1 - Curvas de oferta e demanda por um Bem, ponto de equilíbrio do mercado e preço de equilíbrio de determinado bem.

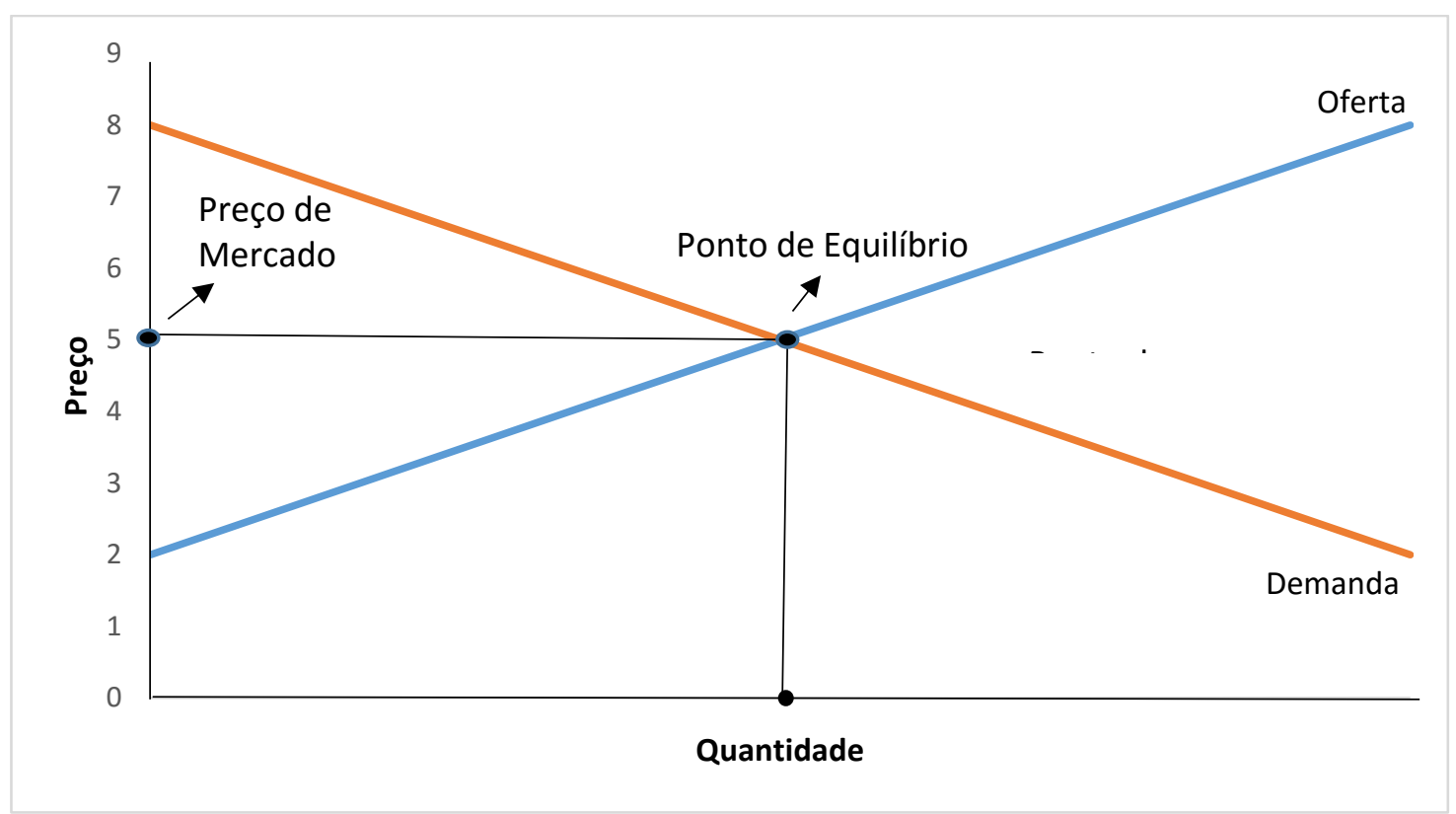

Fonte: Própria autoria.

Como se pode verificar na figura 1 , o ponto de equilíbrio de mercado ocorre na intersecção das curvas de demanda e oferta do bem, onde se estabelece o preço de mercado do mesmo. No ponto de equilíbrio, de acordo com Varian (2006), todo agente disposto a pagar o preço de mercado do bem poderá adquiri-lo, ao passo que todo proprietário de determinado bem poderá vendê-lo ao preço de mercado. Na figura acima, o preço de reserva deste bem, ou seja, o preço máximo que os consumidores pagariam por este bem, é de $\mathrm{R} \$ 8$. Da mesma maneira, o preço mínimo que os ofertantes estariam dispostos a comercializar este bem no mercado é de $\mathrm{R} \$ 2$, sendo que o preço de equilíbrio deste bem é de $\mathrm{R} \$ 5$.

Pode-se observar, no quadro a seguir, uma síntese de fatores que podem alterar a oferta, a demanda e, consequentemente, o mercado do cavalo $\mathrm{BH}$. 
Quadro 1 - Causas de deslocamento nas curvas de oferta e demanda do Cavalo BH.

\begin{tabular}{|l|l|}
\hline Demanda & Oferta \\
\hline Preço de outras raças de hipismo & $\begin{array}{l}\text { Preço de insumos (itens utilizados na } \\
\text { criação do animal) }\end{array}$ \\
\hline Preço de outras atividades de lazer & $\begin{array}{l}\text { Tecnologias utilizadas na criação do } \\
\text { animal }\end{array}$ \\
\hline Renda do consumidor & Expectativas dos ofertantes \\
\hline Gosto, preferência por outras raças & \\
\hline Gosto, preferência por outros hobbies & \\
\hline Expectativas dos demandantes & \\
\hline
\end{tabular}

Fonte: Própria autoria

Realizada a identificação dos fatores que afetam a demanda e a oferta do cavalo $\mathrm{BH}$, sob a ótica da Economia Neoclássica, se torna necessária a reflexão de eventual contribuição da Nova Economia Institucional (NEI), que pode agregar conhecimento à análise, possibilitando o entendimento, por exemplo, da razão de haver a necessidade da existência de instituições como associações de criadores, a presença de custos nas transações entre vendedores e compradores, e a existência de assimetria de informações entre os agentes do mercado. 


\section{A.3 CONTRIBUIÇÃO DA NOVA ECONOMIA INSTITUCIONAL (NEI)}

A Nova Economia Institucional (NEI) trabalha com os pressupostos de que existem custos na utilização do sistema de preços e na condução dos contratos, e de que as transações ocorrem em um ambiente institucional estruturado, em que as instituições não são neutras, ou seja, estas interferem nos custos de transação (ZYLBERSZTAJN, 1995).

Williamson apud Zylbersztajn (1995) define os custos de transação ex-ante como os custos de preparar, negociar e salvaguardar um acordo, e os custos ex-post como decorrentes de ajustes e adaptações de um contrato.

A teoria, como aponta Zylbersztajn (1995), trabalha com os pressupostos comportamentais de racionalidade limitada - em que o agente deseja otimizar, porém não consegue atender tal vontade - e oportunismo, que reflete o resultado da busca do auto-interesse do indivíduo e que parte do princípio de jogo não cooperativo, sendo que a informação não é acessível aos dois agentes, fazendo com que um deles tenha benefícios do tipo monopolístico, muito embora, o auto-interesse possa ser alcançado de maneira não oportunista.

Por conta de tais pressupostos comportamentais, torna-se necessária a inclusão de salvaguardas ou de monitoramento dos contratos, sendo que ambos estão ligados a custos. Os mesmos pressupostos possibilitam a análise de características dinâmicas dos contratos, como tradição, confiança, relações familiares e ambientes sociais que coíbem ações oportunistas, tais como "clãs", cooperativas, empresas familiares e qualquer arranjo que impeça o oportunismo (ZYLBERSZTAJN, 1995). Uma vez que a racionalidade é limitada, os contratos se tornam incompletos, fato agravado pela existência do oportunismo. As transações têm como atributo a frequência, a incerteza e a especificidade dos ativos. Em um contexto de mercado competitivo e globalizado a competitividade de cada firma torna-se fundamental (ZYLBERSZTAJN, 1995).

Farina (1999) afirma que, enquanto a economia clássica busca a otimização de recursos de acordo com determinada alocação de fatores, a NEI tem objetivo de assinalar a forma mais eficiente de organizar as transações econômicas, de modo que a conformação modifique as condições iniciais de alocação de tais recursos. Neste sentido, a autora aponta o conceito de competitividade como sendo "a capacidade sustentável de sobreviver e, de preferência, crescer em mercados correntes ou em novos mercados", sendo a sustentabilidade a realização de lucro positivo (FARINA, 1999, p. 149).

Neste contexto, pode-se analisar a criação de cavalos, em que, muitas vezes não opera com lucro econômico positivo, como apontam Aldridge, Koenen e Phillipsson (2004), ao 
constatarem que muitos dos criadores de cavalos de 19 raças europeias estudados continuam ativos no mercado, mesmo sem obter lucro positivo, pelo fato de gostarem dos animais e de sua criação.

Por conta da definição de competitividade pode-se escolher indicadores para avaliar o desempenho da empresa, como a evolução da participação da mesma no mercado e avaliação dos custos e produtividade como indicadores de eficiência. Farina (1999) afirma ainda que a inovação em produto e processo também gera bom desempenho da empresa. Nesse contexto, a utilização de biotecnologias de reprodução como IA e TE possibilita a diferenciação dos equinos oferecidos no mercado nacional. Além destas, outras inovações surgem na equideocultura constantemente, como tecnologias de nutrição, equipamentos para exercitar os animais, equipamentos para melhoria da saúde dos mesmos, como raios infravermelhos, etc. A utilização destas tecnologias inovadores faz com que o produto oferecido no mercado seja diferenciado do demais.

Segundo Farina (1999), a evolução da participação da firma no mercado é consequência da competitividade, por conta de vantagens competitivas já obtidas. Também é reflexo da adequação da empresa aos padrões vigentes no mercado, tais como preço, regularidade da oferta, diferenciação de produtos, lançamento de novos produtos, entre outras. A autora aponta, ainda, que a competitividade futura é determinada pela capacidade de ação estratégica, marketing, investimento em inovação e em recursos humanos.

Aplicando tal conceito à criação de cavalos, pode-se sugerir que aos criadores de cavalo torna-se necessário o constante aperfeiçoamento genético de seus animais, investimento em tecnologias para o bem-estar e desenvolvimento dos mesmos, como afirmaram Henessy e Quinn (2006) em seu estudo sobre o cavalo de esporte irlandês. Além do mais, a produção exige mão de obra cada vez mais qualificada. Os sistemas de gerenciamento dos criadores precisam, de acordo com os autores, acompanhar a constante evolução dos ambientes institucionais e usuários de cavalos. A competitividade de cada criador será estabelecida de acordo com a adequação às mudanças do mercado e às novas tecnologias que surgirem.

A contribuição da NEI é importante no sentido de auxiliar a compreender a existência de um ambiente institucional organizado, salvaguardas às negociações, etc. para garantir que as transações ocorram de forma a tentar evitar que haja o oportunismo por parte dos agentes, esclarecendo que estas instituições interferem nos custos destas transações realizadas em determinado mercado. Além do mais, a NEI o possibilita melhor entendimento de alguns dos estudos já citados e outros que serão abordados oportunamente, bem como de alguns planos e 
de políticas de desenvolvimento apresentados em alguns países, visando o fortalecimento da indústria do cavalo. 


\subsection{ESTUDOS SOBRE MERCADOS, MERCADOS DE CAVALOS E DE SERVIÇOS RELACIONADOS}

Akerlof (1970) estudou a qualidade dos produtos e a incerteza contida nos diferentes mercados. A existência de diferentes graus de qualidade de produtos pode explicar importantes instituições do mercado. Seu estudo apresenta um modelo que elabora os custos econômicos da desonestidade por parte dos agentes. $\mathrm{O}$ autor aponta que existem muitos mercados em que os compradores usam alguma estatística para julgarem a qualidade das compras como perspectiva. Nesses casos, existe um incentivo para que os vendedores comercializem mercadorias com baixa qualidade, uma vez que o retorno para bens com uma boa qualidade é afetado por conta do conhecimento geral do grupo inteiro de vendedores. O autor usa o mercado de carros usados para exemplificar tal situação. Nesse mercado existe uma grande diferença de preço entre os carros novos e os carros usados.

O autor denomina os carros ruins como "limões", sendo que um carro novo pode ser um bom carro ou um "limão", e o mesmo acontece com os carros usados. Os indivíduos desse mercado compram um carro usado sem saberem se este é um bom carro ou um "limão". Os carros têm probabilidade "q" de serem um bom carro e de "1-q" de serem um "limão". Após um período de tempo possuindo os carros, seus donos podem formar a ideia de o mesmo se tratar de um bom carro ou um "limão". Existe uma assimetria de informação neste mercado, e os bons carros como os carros ruins são vendidos a um mesmo preço. Pelo fato de existir a assimetria de informação, um carro usado tem seu valor de revenda menor do que o carro novo, porque aquele pode ser um bom carro ou um "limão". No modelo apresentado pelo autor, a confiança é importante. As garantias informais são pré-condições para o comércio e a produção. Em mercados em que estas garantias são indefinidas, o negócio sofre. $\mathrm{O}$ aspecto da incerteza foi explorado pelo autor por meio da Teoria dos Jogos, com o chamado "dilema do prisioneiro". O mais difícil é distinguir boa qualidade de má qualidade e isto pode explicar a existência de muitas instituições e pode ser um dos mais importantes aspectos da incerteza.

Neste sentindo, a criação de cavalos também possui grande assimetria de informação. Os criadores ou os proprietários (no caso da revenda dos animais) possuem mais informações do que os possíveis compradores. Os proprietários dos animais podem saber de algum comportamento do animal que seja negativo e que possa não estar aparente durante o período em que o possível comprador faz o teste no animal. Além disso, pode haver algum problema de saúde do animal que passe despercebido nos exames veterinários realizados, na maioria dos casos, antes de se consolidar a compra do equino. Mas, diferentemente do que ocorre com os 
carros usados, o valor dos equinos tende a aumentar com o passar do tempo (no caso de o animal se desenvolver no esporte de forma positiva, tendo bom desempenho em competições e boa saúde).

Muto (1983) analisou o mercado de cavalos Bohm-Bawerk, na Áustria, e concluiu que toda a compra levava a um Ótimo de Pareto. De acordo com o autor, em um mercado como este existem $m$ vendedores, cada um com um bom cavalo, e $n$ compradores, cada um esperando comprar um bom cavalo. Cada vendedor avalia o preço que seu animal vale e cada comprador estabelece um preço máximo ao qual está disposto a pagar por um animal. Uma alocação é considera ótima de Pareto quando a situação não tem como ser melhor para um dos agentes, sem necessariamente piorar a situação do outro agente envolvido na transação. $O$ autor observou que preços e alocações finais poderiam surgir sob um comportamento estratégico (ou sofisticado) de compradores quando os produtos são homogêneos em um leilão sequencial de bens, sendo leiloado um bem de cada vez. Foi demonstrado, usando um jogo de equilíbrio perfeito, que os preços e as alocações finais variam dependendo da ordem em que os bens são leiloados. Entretanto, em oposição ao caso em que os compradores dão um lance sincero, o número de bens vendidos é sempre inalterado e as alocações finais das transações são sempre situações ótimas de Pareto em qualquer sequência de leilões.

Ainda de acordo com Muto (1983), os animais são passados para um leiloeiro, que tem como função vendê-los a um preço mais alto do que seus vendedores estabeleceram. $\mathrm{O}$ autor enumera algumas suposições no que diz respeito ao trabalho do leiloeiro. Em primeiro, cada animal é oferecido um de cada vez. Em segundo, cada animal é vendido pela oferta mais alta dos compradores, que levantam suas mãos oferecendo seu lance. Em terceiro, existe um incremento mínimo ao qual os lances são feitos. Em quarto lugar, se existem $s$ compradores dispostos a dar o mesmo lance, então o comprador terá a probabilidade de $1 / s$ de adquirir seu bem. Em quinto, no final de cada leilão, o leiloeiro anuncia o que aconteceu no mesmo, apontando quais foram seus compradores e a que preço. Em sexto, o preço mínimo e a ordem do leilão são anunciadas com antecedência aos compradores. Em sétimo lugar, os compradores sabem qual o preço máximo que seus competidores estão dispostos a pagar por cada animal. Tal estudo é importante por mostrar que na comercialização do cavalo, tanto comprador quanto vendedor chegam a um acordo que possibilita que ambas as partes ganhem com a transação, sendo que nenhum dos dois poderiam estar em situação melhor, caracterizando um tipo de estratégia entre as partes envolvidas como ganha-ganha. Os dois únicos comentários a se fazer com relação a este estudo são os de que, na realidade, os possíveis compradores de determinado animal em um leilão, não sabem qual o preço máximo seus "concorrentes" estão dispostos a 
pagar. Além disso, os animais oferecidos não podem ser considerados como produtos homogêneos, uma vez que cada equino é único, por conta de sua morfologia, saúde, temperamento, desempenho no esporte ao qual é direcionado, etc.

Grimes e Ray (1991) analisaram a indústria do cavalo dos Estados Unidos e verificaram que aquela apresentava um comportamento de auto-regulação curioso. A maioria dos criadores utilizavam a inseminação artificial na produção de novos potros. Enquanto argumentos administrativos e genéticos para regulação são citados pelos registros das raças, os autores demonstram que as regras dos criadores dependem das consequências econômicas da nova tecnologia. Um modelo de decisão de auto-regulação foi apresentado pelos autores e testado empiricamente.

De acordo com Grimes e Ray (1991) as associações de raças eram, originalmente, organizadas por proprietários de cavalos como uma forma de promover características específicas de uma raça em particular e manter a pureza e qualidade através da cuidadosa manutenção de registros de linhagem. Os registros da raça, controlados por membros que possuíam cavalos registrados, estabeleciam suas próprias orientações e requisitos nos quais os cavalos poderiam ser registrados na associação. Shows, competições e outras atividades eram realizadas e patrocinadas por um registro particular.

Gordon (2001) estudou a contribuição da indústria do cavalo para a economia australiana. O estudo estimou que a indústria contribuía, em 2001, com A $\$ 6,2$ bilhões por ano. A contribuição era mensurada em termos de produto final. Se o valor do trabalho voluntário fosse incluído, a contribuição totalizaria A\$ 8 bilhões por ano. Enquanto as corridas e as atividades associadas contribuíam com um pouco mais da metade, os negócios de cavalos, eventos equestres e de raças e a manutenção dos cavalos eram segmentos muito significativos. O estudo concluiu que o desenvolvimento de um modelo de equilíbrio geral poderia ser por demais exigente no que se refere aos dados, e esses nem sempre estão disponíveis para possibilitar o desenvolvimento de um modelo como esse.

O estudo pioneiro no Brasil, de Lima, Shirota e Barros (2006), concluiu que a indústria do cavalo brasileira movimentava, naquele ano, de $\mathrm{R} \$$ 7,5 bilhões e gerava 3,2 milhões de empregos diretos e indiretos. Estudos desta natureza são ainda raros no país.

Aldridge e Koenen (2002) estudaram a evolução genética de cavalos de esporte em uma perspectiva internacional. De acordo com os autores, o objetivo das organizações de criação de cavalos é o de melhorar a habilidade genética de cavalos de montaria warmbloods $^{11}$ para o

${ }^{11}$ São as diversas raças de cavalos utilizadas para o esporte. A expressão tem como tradução literal "sangue quente". 
desempenho em competições de esporte. Os cavalos são usados para diferentes modalidades, incluindo o adestramento, o salto e o concurso completo de equitação. As 43 organizações membros da Federação Mundial de Criadores do Cavalo de Esporte registravam, anualmente, 130.000 potros, sendo que destes, $80 \%$ eram criados na Europa. O estudo concluiu que a baixa transparência nos programas de criação de cavalos constituía o maior obstáculo para os criadores quando estes se esforçam para usar material genético de outros países. A validação e implementação de métodos correntes não iriam somente melhorar a eficiência da seleção de programas nacionais de criação, mas também estabeleceriam a base essencial para uma evolução internacional da genética de cavalos de esporte.

Um plano para a indústria equina da Austrália, para o período de 2002 a 2006, foi estabelecido (PLAN..., 2002). De acordo com o mesmo, foram elaborados 61 planos de desenvolvimento para esta indústria naquele país, com a publicação de 53 artigos sobre o tema. Como objetivos do plano foram estabelecidos: manter a Austrália livre das doenças exóticas de equinos e limitar o impacto de doenças endêmicas; encorajar o uso de técnicas modernas de tecnologia genética; melhorar o manejo de cavalos em crescimento e desenvolvimento; aumentar o uso de técnicas de imagem para o diagnóstico precoce de doenças e melhora no tratamento; melhorar a qualidade por meio da capacitação humana; melhorar o entendimento e promover a performance econômica da indústria do cavalo; melhor quantificar o impacto ambiental da indústria; melhorar a saúde e o bem-estar do cavalo e melhorar a segurança na indústria.

Uma vez constatada a relevância das indústrias do cavalo na Austrália e no Brasil, o plano australiano sugere a importância de que seja desenvolvido um planejamento de fortalecimento, melhoramento e direcionamento da indústria do cavalo brasileira. Além do mais, medidas mais eficazes contra a proliferação de doenças, como o caso do mormo (que tem registrado casos pelo Brasil) se tornam necessários.

O trabalho “A Report..." (2004) apontou quais eram as pesquisas recentes sobre a indústria de cavalos da Inglaterra e concluiu que 50.000 pessoas eram empregadas na indústria no país, sendo que 11 milhões de pessoas tinham algum interesse na mesmo; 5 milhões de consumidores tinham interesse ativo nesta indústria; 2,4 milhões de pessoas montavam a cavalo na Inglaterra. O número de cavalos no país foi estimado em 600.000 à época. Fazendo-se comparativo com a indústria brasileira, apesar de o número de empregos na indústria do cavalo inglesa ser menor (no Brasil em 2006 eram 3,2 milhões, de acordo com Lima, Shirota e Barros), a quantidade de pessoas que que montavam a cavalo na Inglaterra era mais elevada (no Brasil, 
eram 50 mil praticantes dos diversos esportes hípicos, de acordo Lima, Shirota e Barros, 2006, destes somente 9 mil eram filiados à alguma federação de esporte hípico).

Anderson e Johansson (2004) estudaram a importância da indústria europeia do cavalo para a sua agricultura. De acordo com os autores as políticas de desenvolvimento da União Europeia têm seu foco em iniciativas de desenvolvimento rural. O setor dos cavalos possibilita algumas oportunidades. Um modelo foi utilizado para examinar o valor agregado dos efeitos do setor do cavalo na agricultura sueca. O potencial máximo do setor girava em torno de $12 \%$ do total da contribuição para a agricultura.

De acordo com Egbert (2007) um mercado é uma organização e, com tal, estabelecida pela cultura que a cerca, e esta, por sua vez, está baseada em costumes, tradições, leis e crenças. Todas essas características são pontos em comum de determinadas pessoas. No artigo em questão, o autor afirma que o foco do seu estudo foram os mercados que ele denominou de "mercados de cavalos ao ar livre". Todavia o autor adverte que existem outras formas de mercado para o animal. O autor afirma que os mercados são compostos de pessoas racionais que possuem espírito empreendedor, produtores, comerciantes e membros de organizações seculares. De acordo com ele, os mercados parecem envolver espontaneidade e afirma que podem funcionar perfeitamente bem sem a intervenção governamental.

Egbert (2007), ao revisar a documentação do mercado de Brockumer Market ${ }^{12}$ nos últimos cem anos, constatou que houve um declínio no número de cavalos oferecidos. Em 1924 eram 1.300 cavalos, 1.100 em 1935, 700 em 1950 e apenas 300 em 1989. A demanda por cavalos na agricultura, indústria e uso militar foi trocada pela demanda por cavalos para o esporte e entretenimento. Nos três mercados estudados pelo autor, o número de cavalos à venda flutuou entre 50 e 350 de 1997 a 2002. Segundo ele, o mercado de cavalos ocorre em um dia determinado, e começa as sete e meia da manhã. Os criadores levam seus cavalos até o mercado, e o número de pessoas que o visitam por dia é de cerca de 30.000. O número de visitantes das feiras excede em muito o número de habitantes das vilas que o sediam, e os consumidores percorriam uma distância de até 100 quilômetros para visitar as feiras.

Segundo Egbert (2007), as instituições específicas que regulavam o comportamento do mercado aberto de cavalos eram caracterizadas por quatro elementos:

1. As autoridades locais providenciam regras formais para o mercado (vendedores) e providenciam a infraestrutura necessária para o comércio. As regras formais incluem uma pequena taxa de venda para os vendedores e para o controle veterinário dos animais

\footnotetext{
${ }^{12}$ Mercado de animais e máquinas agrícolas localizado no norte da Alemanha.
} 
à venda. Um padrão mínimo de qualidades dos animais é garantido por regras formais. É totalmente proibido oferecer animais doentes e até mesmo transportá-los até o mercado.

2. A barganha, como instituição essencial do mercado aberto, se dá como se segue: os cavalos são amarrados em pranchas de madeira e a multidão anda por entre eles. Se um visitante se interessa por um cavalo, este começa a examinar seus dentes, cascos, crina e por assim por diante. Depois, pergunta ao vendedor o preço (o qual, geralmente, será além do preço final a ser acertado). O potencial comprador após analisar todos os detalhes do animal em questão anuncia um preço bastante baixo, o qual estaria disposto a pagar pelo mesmo. Após seu anuncio a barganha se inicia, um vendedor e um comprador, frente a frente, tipicamente em voz alta falam seus argumentos, os quais não são necessariamente referentes ao animal, eles podem inclusive ser irônicos e se insultarem. Uma vez que um vendedor e um comprador iniciam sua barganha, afirma Egbert (2007), as pessoas se aglomeram à sua volta, sendo que um ritual essencial é uma salva de palmas após o anúncio de cada possível preço. A barganha pode se encerrar a qualquer momento, sendo que se ambas as partes chegam a um consenso, animal e dinheiro mudam de donos no mesmo dia.

3. Uma lei primordial é obedecida na venda de cavalos: A "Lei do Imperador" sobre as principais deficiências e período de garantia. De acordo com esta Lei, o vendedor pode ser responsabilizado por deficiências que o cavalo venha a apresentar em um período de 14 dias, deficiências estas que não podem ser previstas pelo comprador no momento da breve inspeção. Esta lei é bem conhecida pelos participantes do mercado, e, aparentemente, tem funcionado adequadamente ${ }^{13}$.

4. A língua falada no mercado pode ser considerada outra instituição. A língua mais utilizada é o alemão, em seus mais diversos dialetos.

De acordo com Egbert (2007), essas instituições contribuíam para o bom funcionamento do comércio de cavalos. Uma vez que os cavalos são bens únicos, os potenciais compradores sofrem com restrições de informação e, consequentemente, com altos custos de informação. A assimetria de informação quanto à qualidade do cavalo possibilita um comportamento oportunista pela parte do vendedor. No entanto, tais instituições reduzem os custos de transação.

\footnotetext{
${ }^{13}$ No Brasil, a lei $\mathrm{n}^{\text {o }} 7.291$, de 19 de dezembro de 1984, dispõe sobre as atividades de equideocultura e dá outras providências. Porém, não existe nenhuma regulamentação específica quanto à responsabilidade dos vendedores de cavalos, no caso de a venda ocorrer mesmo se o animal apresentar algum problema de saúde.
} 
Em primeiro lugar, um mínimo de qualidade dos animais é garantido pelas autoridades por meio de exames de saúde. Em segundo, quase todos os contratos são orais, isto se torna possível porque a barganha é conduzida em público e existem testemunhas. A barganha pública possibilita uma rápida transferência de direitos de propriedade, porque reduz ex-post o comportamento oportunista de parceiros de comércio. Egbert (2007) afirma que, em terceiro lugar, os comerciantes são regulados por uma lei especifica que protege o comprador de comportamento oportunista por parte do vendedor, o tornando protegido de doenças que não foram informadas pelo vendedor. Em quarto, uma mesma língua falada em todos os mercados possibilita o processo de barganha.

Vieira (2011) analisou a criação do cavalo Mangalarga no estado de Minas Gerais. Dentre os resultados obtidos na pesquisa, verificou a autora que a média de funcionários empregados na criação dos animais em questão foi de 3,13 por propriedade e que a média de salário destes funcionários era de $\mathrm{R}$ \$ 822,95 (1,51 salários mínimos federais, que na época era de $\mathrm{R} \$ 545,00)$. Na criação dos animais, 56,08\% dos entrevistados forneciam somente pastagem para os animais e 19,19\% deles forneciam feno (comprado ou produzido na propriedade). Com relação ao concentrado, 50,52\% dos entrevistados não o fornecia para os animais; $11,06 \%$ dos criadores elaborava concentrado na propriedade e 30,17\% das fazendas fornecia concentrado comercial. Com relação ao custo com alimentação, a média do custo do concentrado elaborado no criador era de $\mathrm{R} \$ 0,90 / \mathrm{kg}$. Já o concentrado comercial apresentou média de custo de $\mathrm{R} \$$ 1,23/kg. Com relação às biotecnologias de reprodução utilizadas na criação dos animais da raça no estado de Minas Gerais, em 13,11\% os criadores utilizavam a técnica de IA e em 15,95\% faziam uso da TE. Os custos destes manejos reprodutivos variaram entre $\mathrm{R} \$ 185,00$ e $\mathrm{R} \$ 510$ (IA) e R $\$ 1.300$ e $\mathrm{R} \$ 3.000$ (TE). Já os valores de venda dos animais, nos leilões realizados pelos criadores ou pelas associações de raça, oscilaram entre R\$ 2.000 e R\$ 85.000. Esta pesquisa não diferenciou os animais pelas idades dos mesmos, no momento de registrar seus valores de vendas.

De acordo com Oddie et al. (2014) vários são os componentes que determinam o preço de um bem, inclusive de um cavalo. Quando este for o caso, os componentes são tais como a raça, cor, idade, altura, temperamento e capacidade de uso em potencial. Um modelo econométrico foi proposto pelos autores para valorar estas características. Diferentemente do que ocorre em um leilão, o vendedor precisa estimar o preço de seu cavalo quando deseja fazêlo via mercado. Os autores afirmam que pesquisas demonstraram que possíveis características de falta de segurança reduzem o preço estabelecido pelo vendedor, mas que características positivas, juntamente com associadas com segurança para o cavaleiro tiveram um efeito neutro 
sobre o preço anunciado. Os autores desenvolveram uma regressão para estabelecer o preço de cavalos na Austrália. Pesquisaram tanto os animais de raça renomadas, utilizadas no esporte como os warmbloods, entre outros, e os animais somente para recreação (sem raças renomadas ou sem raças definidas). Eles afirmam que pesquisaram sobre estes dois tipos de animais porque acreditam que quando uma pessoa vai comprar um cavalo, pode comprar um entre estes dois tipos de animais, dependendo da finalidade a que o mesmo será utilizado, recreação ou esporte.

Para sua pesquisa, Oddie et al. (2014) observaram 524 anúncios com fotos, veiculados na revista australiana HorseDeals, em seis edições consecutivas, considerando somente os cavalos com pelo menos 1,42 m de cernelha, domados, com preço estipulado no anúncio. De acordo com a pesquisa, houve considerável diferença entre o preço de cavalos puro sangue inglês e o de cavalos não puro sangue inglês. Do total de 1.031 anúncios estudados, 524 satisfaziam todos os critérios estipulados pelos pesquisadores, sendo que estes anúncios somavam o equivalente a 2 milhões de dólares australianos. Os pesquisadores identificaram 67 frases utilizadas para descrever o comportamento dos animais, eleitas pelos anunciantes, sendo que essas foram divididas em quatro categorias. Três destas categorias estavam associadas a comportamentos que garantem a segurança do cavaleiro, e a quarta categoria se refere a avisos negativos com relação a segurança do mesmo. Para cada animal foram registradas as seguintes informações: tamanho do anúncio, preço, altura, idade, sexo, cor, raça, status de registro e estado de origem. As raças com menos de oito exemplares foram classificadas como outras raças. Cada observação referente a um cavalo somava um ponto, sendo assim, um cavalo com três observações somava três pontos, sem a exclusão de outliers. Estatísticas descritivas foram computadas para todas as variáveis. Segundo os autores, os dados dos preços apareceram enviesados e, por esse motivo, foram transformados em logaritmos para reduzir o viés. A regressão foi realizada utilizando os dados transformados dos preços.

A regressão múltipla foi então realizada por Oddie et al. (2014) para identificar as variáveis que influenciaram significativamente os preços para os anúncios de venda de cavalos. As variáveis explanatórias utilizadas no modelo de regressão foram: tamanho do anúncio, idade, raça, registro, sexo, descritores pouco tranquilizadores, soma de experiências, pista de equitação, descritores alarmantes e trabalho. As análises inicias demonstraram que o preço de puro sangue inglês e não puro sangue inglês são significativamente diferentes, como já mencionado. A média de preço para não puro sangue inglês foi de $\mathrm{A} \$ 3.976$, o menor foi de $\mathrm{A} \$$ 950 e o maior de $A \$ 14.000$. A série de preços mostrou que $48 \%$ dos cavalos custavam entre A \$ 2.000 e A\$ 3.999 e 33\% custavam entre A\$ 4.000 e A\$ 5.999. Menos de 2\% dos animais tinham seu preço acima de A $\$ 10.000$. Segundo as análises dos autores, a raça foi informada 
em $72 \%$ dos casos, sendo anunciadas 21 raças diferentes: Quarto de Milha (17\%), Cavalo Australiano (16\%), Clydesdale (10\%) e Árabes (8\%) eram as mais numerosos.

A constante do modelo econométrico de Oddie et al. (2014) foi igual a A \$3.182, sendo este o preço atribuído, pelos autores, ao cavalo "ideal", que não era registrado, com dois anos de idade, da raça Cavalo Australiano, fêmea, com zero de experiência e anúncio de um dezesseis avo de página. Este tipo de animal foi o mais recorrente nos anúncios. As variáveis de altura, idade, cor, estado de origem, tipos específicos de experiência atlética (salto, adestramento), maioria das raças, alertas de comportamento associados com segurança para o cavaleiro não tiveram influência significante no preço dos anúncios. Não houve interação significante entre idade e experiência. Houve um efeito linear significativo no que diz respeito a experiência, mas a idade mostrou significância a partir de 16 anos de idade. As variáveis que foram consideradas como significantes no preço final do animal foram certas raças, registro, trabalho, sexo, alarmes de comportamento, tamanho do anúncio e experiência.

O estudo de Oddie et al. (2014) mostrou que variáveis tais como raça, cor e idade são importantes para a precificação do cavalo, indicando que houve diferença entre o preço dos cavalos puro sangue inglês das outras raças. Tal informação é importante por corroborar a ideia de que raças diferentes podem ter preços diferentes no mercado de cavalos.

Por sua vez, Mcgreevy et al. (2015) observaram se os cavalos puro sangue inglês (PSI) são bem valorados na Austrália, no momento da sua venda. Bower et al. Apud Mcgreevy et al. (2015) afirmam que por séculos o PSI vem sendo selecionado para corridas. Usando praticamente a mesma metodologia de Oddie et al. (2014), analisando inclusive os anúncios utilizados em tal estudo, Mcgreevy et al. (2015) estudaram anúncios em revistas considerando tamanho do anúncio, preço, altura do animal, idade, sexo, cor, status de registro e estado de origem. Os anúncios contendo frases de experiência de performances foram ranqueados com um ponto cada. Os critérios incluídos no estudo foram: se o animal anunciado tem pelo menos $144,3 \mathrm{~cm}$ (ou $14 \mathrm{hh}$ - palmos -, sendo que um palmo equivale a 10,2 cm); um animal que tenha treinamento (domado) e seja considerado apto para a montaria (o que excluí cavalos que nunca tenham sido montados, éguas de cria e garanhões utilizados somente na reprodução); um preço específico (qualquer anúncio em que o preço estava a combinar, preço compatível com o mercado, etc.) foi excluído e cavalos identificados como PSI (cavalos de outras raças foram excluídos). Do total de 1.031 anúncios estudados, 220 satisfaziam esses critérios. Os cavalos PSI são utilizados em todo o mundo em corridas, sendo que quando são descartados das corridas, são utilizados para a prática do esporte por lazer, ou até mesmo o esporte profissional (caso do CCE). 
Após ajustarem sua regressão, Mcgreevy et al. (2015) obtiveram como resultado que a média de preço de cavalos PSI era de A \$3.286, tendo valor mínimo de A \$ 900 e máximo de A \$ 10.950. A distribuição da série de preços era positivamente enviesada, com a faixa de preço mais comum sendo A $\$ 2.000$ a A 3.999 (52\% da amostra), seguido de A\$ 4.000 a A \$ 5.999 (30\%). Os cavalos tinham idade entre 3 a 18 anos, sendo que somente 7\% dos cavalos tinham idade entre 3 e 5 anos $(n=16)$. Os cavalos com idades entre 6 e 10 anos eram $46 \%$ da amostra e 5\% dos anúncios não continham a informação da idade do animal $(\mathrm{n}=10)$. A maioria dos cavalos não era registrada ( $\mathrm{n}=191$ ou 87\%), o que, de acordo com os autores, não significava que os cavalos nunca haviam corrido, mas sim que não vinham direto das corridas para o mercado de equitação recreativa. De fato, a revista Horse Deals havia separado uma seção para cavalos que deixaram de correr. Frases contendo termos de segurança aparecerem em $45 \%$ dos anúncios e alertas negativos com relação à segurança em 54\%, sendo que neste caso, 64\% usaram um alerta uma vez, $34 \%$ duas vezes e um animal foi anunciado com três alertas. O total de 38 anúncios (17\%) continha pelo menos um alerta e incluía, ao menos, um termo considerado muito tranquilizador com relação à segurança do cavaleiro. A regressão teve como resultado uma constante de A \$ 3.286, sendo que este preço se refere a um PSI sem registro, fêmea, com média de experiência zero, usando um dezesseis avos de página de anúncio. Como conclusão, o estudo aponta que existe uma diferença na precificação de cavalos PSI de cavalos não PSI, o que comprova que diferentes raças têm seus preços diferenciados pelo mercado de cavalos.

A produção e o mercado de cavalos de esporte ainda são pouco estudados, necessitando de maiores informações para que se torne possível o aperfeiçoamento da produção dos equinos. Os estudos se concentram na Europa e nos Estados Unidos. Observou-se que a indústria do cavalo movimenta parcela significativa de capital ao redor do mundo e que existe a preocupação com o melhoramento genético dos animais produzidos, visando o melhor desempenho dos mesmos. 


\section{MATERIAIS E MÉTODOS}

Esta pesquisa baseou-se em estudo exploratório-descritivo que, de acordo com Lakatos e Marconi (2006), considera a finalidade de descrever determinado fenômeno, em que se pode encontrar descrições quantitativas como qualitativas, tendo como uma das técnicas utilizadas a observação participante e o uso de formulários ou questionários. Os formulários e questionários, afirmam os autores, se diferenciam pelo método de pesquisa: se feito pessoalmente (formulários) ou feito sem a presença do pesquisador, como via internet (questionários). Os estudos exploratórios têm as técnicas de amostragem flexibilizadas. Um estudo exploratóriodescritivo é feito quando um fenômeno ainda é pouco estudado, buscando-se levantar informações iniciais do objeto de estudo. Desta maneira, buscou-se o levantamento de informações qualitativas e quantitativas do mercado e produção do cavalo BH e realizou-se o uso de estatística descritiva.

Foram levantadas informações da criação do Cavalo Brasileiro de Hipismo na associação dos criadores (quantidade de registros na associação, transferência de propriedade dos animais, mapeamento dos criadores no estado de São Paulo, biotecnias de reprodução permitidas, média de preços dos animais vendidos em leilões realizados pela entidade).

A escolha pela técnica de coleta de dados com a utilização de formulários e questionários mistos contendo questões de múltipla escolha e questões abertas favoreceu o levantamento de informações gerais e específicas. Nesse sentido, elaborou-se um formulário e um questionário para os criadores do cavalo $\mathrm{BH}$ (ofertantes) e outro formulário e questionário para os praticantes de esporte hípico e/ou proprietários de cavalos (demandantes). Os formulários e questionários destinados aos criadores contêm a mesma estrutura de perguntas, bem como os formulários e questionários destinados os demandantes, sendo que o que o diferencia é o método de aplicação do mesmo (pessoalmente ou via internet). O questionário aplicado aos ofertantes do cavalo BH teve por objetivo captar o modelo de negócio da criação do cavalo Brasileiro de Hipismo, e atendeu aos objetivos de levantar informações sobre o mercado e produção de equinos, determinar os principais destinos dos cavalos e estimar o custo médio de produção e manutenção dos animais. O questionário direcionado aos demandantes visou levantar informações sobre os usuários do cavalo da raça $\mathrm{BH}$, bem como suas preferências, e atendeu aos objetivos de determinar quais os principais usos dos cavalos, fazer a tipologia dos usuários dos cavalos da raça e levantar o custo médio de manutenção dos animais. Para que não fosse feito viés de seleção dos demandantes, foram entrevistados usuários de cavalos de diversas raças, incluindo o $\mathrm{BH}$. 
A aplicação dos formulários e questionários ocorreu pessoalmente ou via internet. Os criadores entrevistados pessoalmente se localizam nas cidades de Pirassununga (haras que teve diversos animais de sua criação com bons desempenhos em competições internacionais). $\mathrm{O}$ Haras da Escola de Equitação Guega; um haras da cidade de Batatais. Alguns haras responderam o questionário por meio da internet, como foi o caso de um haras localizado na cidade de Arandú, que se trata de um dos maiores e mais tradicionais criadores da raça, outro na cidade de Porto Feliz ${ }^{14}$ e um terceiro localizado na cidade de Ribeirão Preto.

Como ofertantes do cavalo $\mathrm{BH}$ foram considerados os haras produtores de animais da raça, credenciados na $\mathrm{ABCCH}$. Os demandantes do cavalo $\mathrm{BH}$, por sua vez, foram os praticantes de esporte, proprietários ou não de cavalos (independentemente da raça do animal) e os proprietários de cavalos, praticantes ou não de esporte hípico. Os ofertantes de cavalos da raça foram entrevistados pessoalmente, em visitas aos haras criadores, também via telefone ou por meio da internet. Os demandantes entrevistados pessoalmente foram abordados no Centro Hípico Pagoto, localizado em Pirassununga ${ }^{15}$; e na Escola de Equitação Guega ${ }^{16}$, localizada em Ribeirão Preto.

Como outra etapa do procedimento metodológico, depois de coletadas as informações com a aplicação dos questionários nas áreas de estudo, os dados foram tabulados e organizados em gráficos e quadros, utilizando-se também da aplicação da média aritmética simples e percentual para algumas análises.

O custo médio de manutenção de um animal dispendido pelos criadores foi alcançado através da soma do custo médio com funcionários com a média do custo médio da assistência veterinária, somados a média do custo com concentrado mais a média do custo com feno somados a média do custo mensal com fármacos.

Considerou-se que os animais ingerem $4 \mathrm{~kg}$ de concentrado e feno diariamente, sendo 3 $\mathrm{kg}$ de feno e um de concentrado. Foi considerado somente o cargo de tratador, pois as propriedades apresentaram variações nos cargos de seus funcionários, sendo que os tratadores se encontraram presentes na maioria delas. Custos da terra em que os animais são criados não foram considerados, pois a pesquisa não incluiu questão específica sobre este custo, bem como custos com manutenção de máquinas, energia, água, etc.

\footnotetext{
${ }^{14}$ Alguns haras entrevistados solicitaram sigilo em relação ao seu nome.

${ }^{15}$ O cavaleiro Éder Gustavo Baldin Pagoto representou o Brasil nas Olímpiadas de Sidney, em 2000, e obteve um dos melhores resultados brasileiros individuais na modalidade do CCE. Atualmente atua como cavaleiro profissional e empresário.

${ }^{16} \mathrm{O}$ cavaleiro Serguei Fofanoff, conhecido como Guega, é um dos cavaleiros que mais vezes representou o Brasil em competições internacionais como Jogos Mundiais, Pan-Americanos e Olimpíadas. Atua na modalidade do CCE e possui escola de equitação de grande porte em Ribeirão Preto, onde também produz alguns animais da raça $\mathrm{BH}$.
} 
O custo de manutenção dos animais para os demandantes do Cavalo $\mathrm{BH}$ foi calculado com a média dos custos de aulas e treinamento, estabulagem e alimentação mensais para um animal.

Os questionários direcionados aos criadores de cavalos $\mathrm{BH}$ e também os destinados aos demandantes de cavalos de esporte encontram-se anexos à dissertação. 


\section{RESULTADOS E DISCUSSÃO}

Existiam, no Estado de São Paulo, 1.137 criadores credenciados aptos a criar a raça Brasileiro de Hipismo. Existe o registro de 334 haras criadores na cidade de São Paulo, em nome de pessoa física. Por meio de contatos e pesquisas na internet observou-se que diversos haras cadastrados na cidade de São Paulo estão fisicamente localizados em outras cidades. Um criador que realmente se localiza naquela cidade é o Jockey Club. Pode-se verificar o mapeamento dos criadores no quadro abaixo:

Quadro 2 - Quantidade de criadores do cavalo BH por cidade no Estado de São Paulo.

\begin{tabular}{|c|c|}
\hline Cidades & $\begin{array}{l}\mathrm{N}^{\circ} \text { de haras } \\
\text { por cidade }\end{array}$ \\
\hline São Paulo & 334 \\
\hline Cidade não informada & 46 \\
\hline Campinas & 39 \\
\hline Colina & 32 \\
\hline Sorocaba & 25 \\
\hline Itu & 24 \\
\hline Ribeirão Preto & 19 \\
\hline Avaré & 18 \\
\hline São Carlos & 14 \\
\hline Cotia e Patrocínio Paulista & 13 \\
\hline Barretos & 12 \\
\hline $\begin{array}{l}\text { Boituva, Bragança Paulista, Indaiatuba, Itapetininga, Jaboticabal, } \\
\text { Pirassununga e Porto Feliz }\end{array}$ & 11 \\
\hline Piracicaba & 10 \\
\hline Jundiaí e Salto de Pirapora & 9 \\
\hline Atibaia, Orlândia e Valinhos & 8 \\
\hline Bauru, Marília e Mogi Mirim & 7 \\
\hline $\begin{array}{l}\text { Araçatuba, Cravinhos, Itapecerica da Serra, Itatiba, Limeira, Louveira e } \\
\text { Santos }\end{array}$ & 6 \\
\hline $\begin{array}{l}\text { Barueri, Bebedouro, Ipuã, Itirapuã, Jaguariúna, Mairiporã, Morungaba, } \\
\text { Pindamonhangaba, Piracaia, Piraju, São Joaquim da Barra e São Roque }\end{array}$ & 5 \\
\hline $\begin{array}{l}\text { Arandú, Caieiras, Campos do Jordão, Itapira, Itupeva, Salto, São Miguel } \\
\text { Arcanjo, Vale do Paraíba e Vargem Grande Paulista }\end{array}$ & 4 \\
\hline $\begin{array}{l}\text { Araçoiaba da Serra, Araraquara, Araras, Batatais, Cafelândia, Cesário } \\
\text { Lange, Cristais Paulistas, Dourado, Embu, Grande São Paulo, Guaíra, } \\
\text { Ibiúna, Itaberá, Itapeva, Itatinga, Jaborandi, Jarinu, Júlio Mesquita, } \\
\text { Juquitiba, Morro Agudo, Parelheiros, Santa Rita do Passa Quatro, Santana } \\
\text { do Parnaíba, Santo André e São José do Rio Pardo }\end{array}$ & 3 \\
\hline
\end{tabular}


Continua

Araçoiaba, Brotas, Cabreúva, Iperó, Itaí, Itirapina, Jacareí, Jacutinga, Leme, Lins, Lorena, Mogi das Cruzes, Ourinhos, Paraná, Pedregulho, Piratininga, Pontal, Presidente Prudente, Reginópolis, São João da Boa

Vista, São José dos Campos, São Luís do Paraitin, Tatuí, Taubaté, Tupã e Vargem Grande do Sul

Adamantina, Aguas da Prata, Aguas de Lindóia, Aguas de Santa Bárbara, Alambari, Alfenas, Amparo, Analândia, Angatuba, Arapei, Arealva, Artur Nogueira, Avaí, Bananal, Barra Bonita, Bernardino de Campos, Biritiba Mirim, Bomfim Paulista, Botucatu, Cajuru, Campo Limpo, Campo Limpo Paulista, Carapicuíba, Casa Branca, Cerqueira César, Cerquilho, Cordeirópolis, Corumbataí, Elias Fausto, Embaúba, Embu das Artes, Engenheiro Coelho, Espírito Santo do Pinhal, Fernando Prestes, Garça, Guararema, Guaratinguetá, Guareí, Iacanga, Ipauçú, Jambeiro, Jaú, Jeriquara, Joanópolis, Joaquim Egídio, Mairinque, Mococa, Mombuca, Nova Granada, Nova Odessa, Oriente, Oswaldo Cruz, Palmares Paulista, Paraibuna, Paulo de Faria, Pedreira, Penápolis, Pereira Barreto, Piedade, Pilar do Sul, Pindorama, Pitangueiras, Plameira, Porangaba, Primavera, Quadra, Regente Feijó, Restinga, Rio Grande, Santa Cruz da Conceição, Santa Cruz das Palmeiras, Santa Cruz do Rio Pardo, Santa Gertrudes, Santa Rosa do Viterbo, Santana do Ouro Preto, Santo Antônio da Pose, Santo Antônio Jardim, São Bento do Sapucaí, São Bernardo do Campo, São Caetano do Sul, São Manoel, São Pedro do Turvo, São Simão, São Vicente, Sarapuí, Serrana, Suzano, Tabapuã, Taboão da Serra, Tapiratiba, Tietê, Torrinha, Tremembé, Vinhedo, Viradouro e Votorantim Fonte dos dados: ABCCH. Própria Autoria.

Ferreira informou, por e-mail ${ }^{17}$, que o número de animais registrados na $\mathrm{ABCCH}$, entre os anos de 1995 e 2013, foi de 8.631. Este número vinha crescendo de 1995 a 2011, quando, então, ocorreu queda a cada ano. Essa queda no número de registros de animais pode refletir uma saída de criadores do mercado. Foi constatado que muitos dos criadores registrados na $\mathrm{ABCCH}$ atualmente não estão ativos no mercado. No caso da cidade de Pirassununga, a $\mathrm{ABCCH}$ informou que existiam onze criadores ativos, mas na ocasião somente dois criadores continuavam no mercado: Haras Feroleto Antico e o Haras Cachoeirinha. Visitou-se um destes haras e observou-se defasagem na lista de criadores da $\mathrm{ABCCH}$ : a entidade possui uma lista de todos os criadores que já registraram algum animal ou que se associaram. Porém, não é feito o monitoramento de uma possível saída de criadores do mercado. A entidade não atualizou as informações no que se refere à atividade presente dos criadores.

\footnotetext{
${ }^{17}$ FERREIRA, R. Informações sobre a criação de cavalos da raça Brasileiro de Hipismo. Mensagem recebida por rica.ferreira7@gmail.com em 08 set. 2015.
} 
Segundo relatado pelo senhor Ricardo Ferreira (funcionário da $\mathrm{ABCCH}$,), a queda acentuada se deu por conta do alto custo na produção de cavalos no Brasil, o que fez com que o número de animais produzidos caísse (Figura 2). Por outro lado, a crise econômica que teve início em 2008 pode ter influenciado o comportamento deste mercado.

Figura 2 - Evolução dos registros de cavalos da raça BH no Estado de São Paulo, no Período de 1995 a 2013.

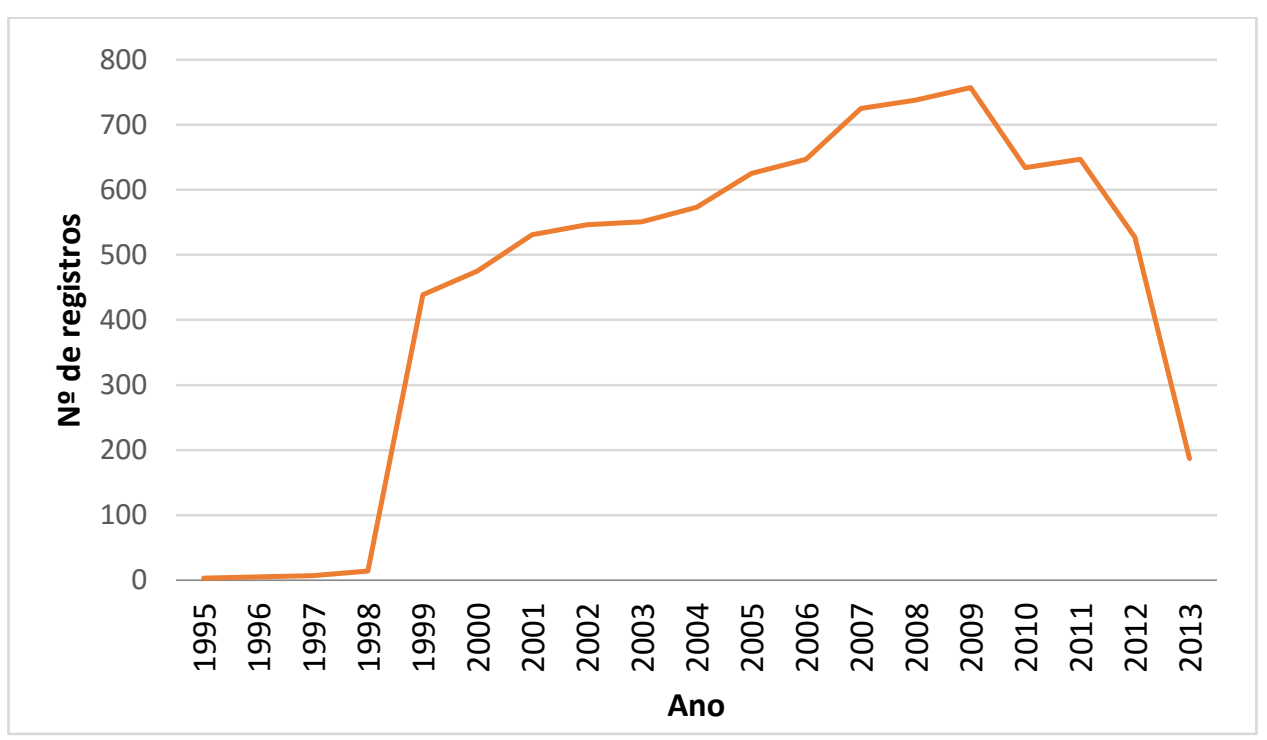

Fonte dos dados: ABCCH. Própria autoria

De forma semelhante com o observado, Egbert (2007), estudando a comercialização de cavalos em três mercados na Alemanha, constatou que houve queda no número de animais oferecidos nesses mercados, principalmente pelo fato de que os animais eram utilizados, antigamente, na agricultura e indústria e, atualmente, são destinados principalmente para a prática de esportes e lazer. No caso do Cavalo $\mathrm{BH}$, como os animais foram destinados, desde a criação da raça, para a prática do esporte, a queda pode ter ocorrido devido ao aumento no custo de produção, como citado ou por ajuste do mercado (a demanda pelos animais pode ter diminuído, o que fez com que os criadores passassem a produzir menos).

A $\mathrm{ABCCH}$ informou que foram realizadas medidas para incentivar o registro de animais da raça, como forma de fomentar a criação dos animais. Desta maneira, esse aumento de registros registrado entre 1998 e 2009 pode ser reflexo destas ações. A queda nos registros observados pode ser explicada por conta deste fomento: houve um boom por conta dos incentivos e, em seguida, a quantidade de registros se normalizou. ${ }^{18}$

${ }^{18}$ KLIEMKE, J. Informações sobre a criação de cavalos da raça Brasileiro de Hipismo. Mensagem recebida por julius@ brasileirodehipismo.com.br recebida em 06 jul. 2016. 
Outro fator que pode reforçar a queda da procura por animais novos é o aumento de comercialização de animais mais velhos ${ }^{19}$, como constatado pelo aumento no número de transferências entre proprietários, entre os anos de 2000 e 2013 (Figura 3)

Figura 3 - Evolução de transferências de cavalos da raça BH no Estado de São Paulo, no período de 2000 a 2013.

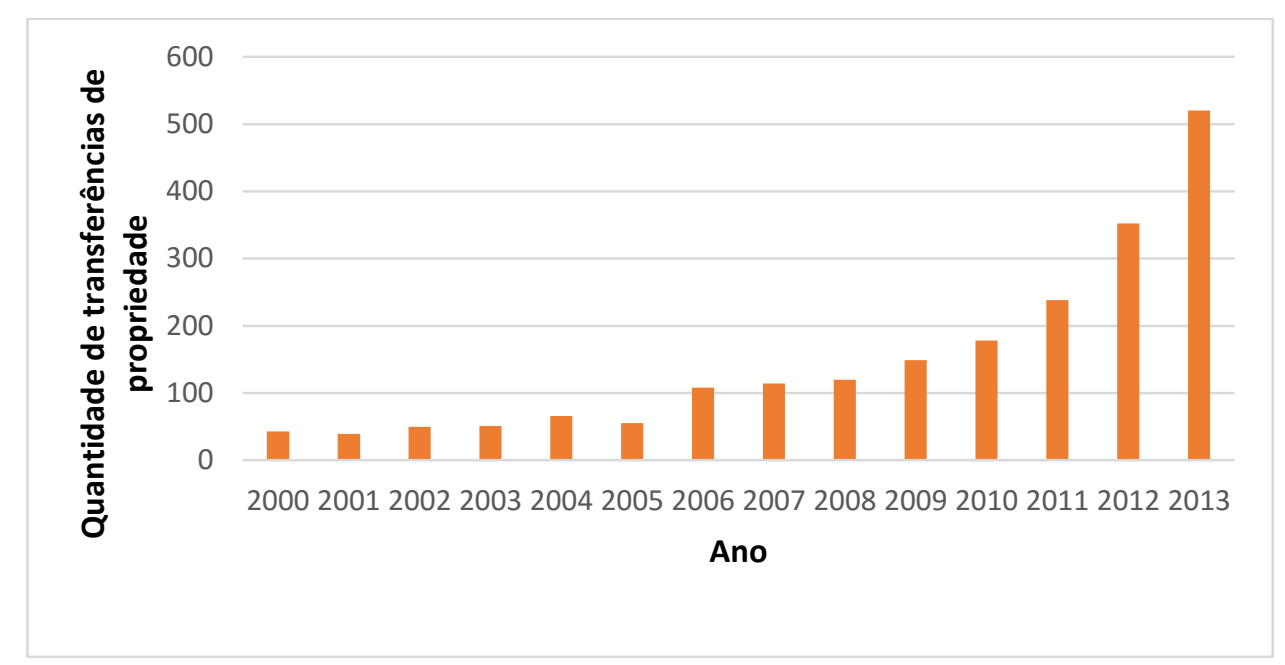

Fonte dos dados: ABCCH. Própria autoria.

Sobre o valor de venda do cavalo no mercado, existe ação dos seus resultados em competições. O animal pode ser vendido a preço mais alto do que o inicial, no caso de bons resultados em competições e boa saúde, situação mais comum no mercado de cavalos.

Para garantir a organização deste mercado, a existência das associações de criadores possibilita o melhor gerenciamento das raças, evitando o oportunismo dos criadores, no sentido de evitar que a linhagem do animal seja perdida. Além disso, as associações promovem a raça, tornando-a mais conhecida e consolidada no mercado, tendo como um dos seus fundamentos o marketing. No caso da $\mathrm{ABCCH}$, por conta do controle de transferência dos animais quando os mesmos são vendidos, a associação se torna intermediária do mercado de cavalos BH que possuem registro. Nesse sentido, considerando o estudo a ótica da NEI, observou-se que o mercado do Cavalo $\mathrm{BH}$ possui um ambiente organizacional relativamente estruturado. Além disso, a $\mathrm{ABCCH}$ fornece, no serviço de registro online, ferramentas de consulta para que se possa verificar a pontuação de determinado animal da raça acumulada por conta de desempenhos em competições.

${ }^{19}$ O Cavalo Brasileiro de Hipismo tem a doma tardia, se comparado a animais de outras raças. 
Figura 4 - Desenho da cadeia da indústria do Cavalo Brasileiro de Hipismo.

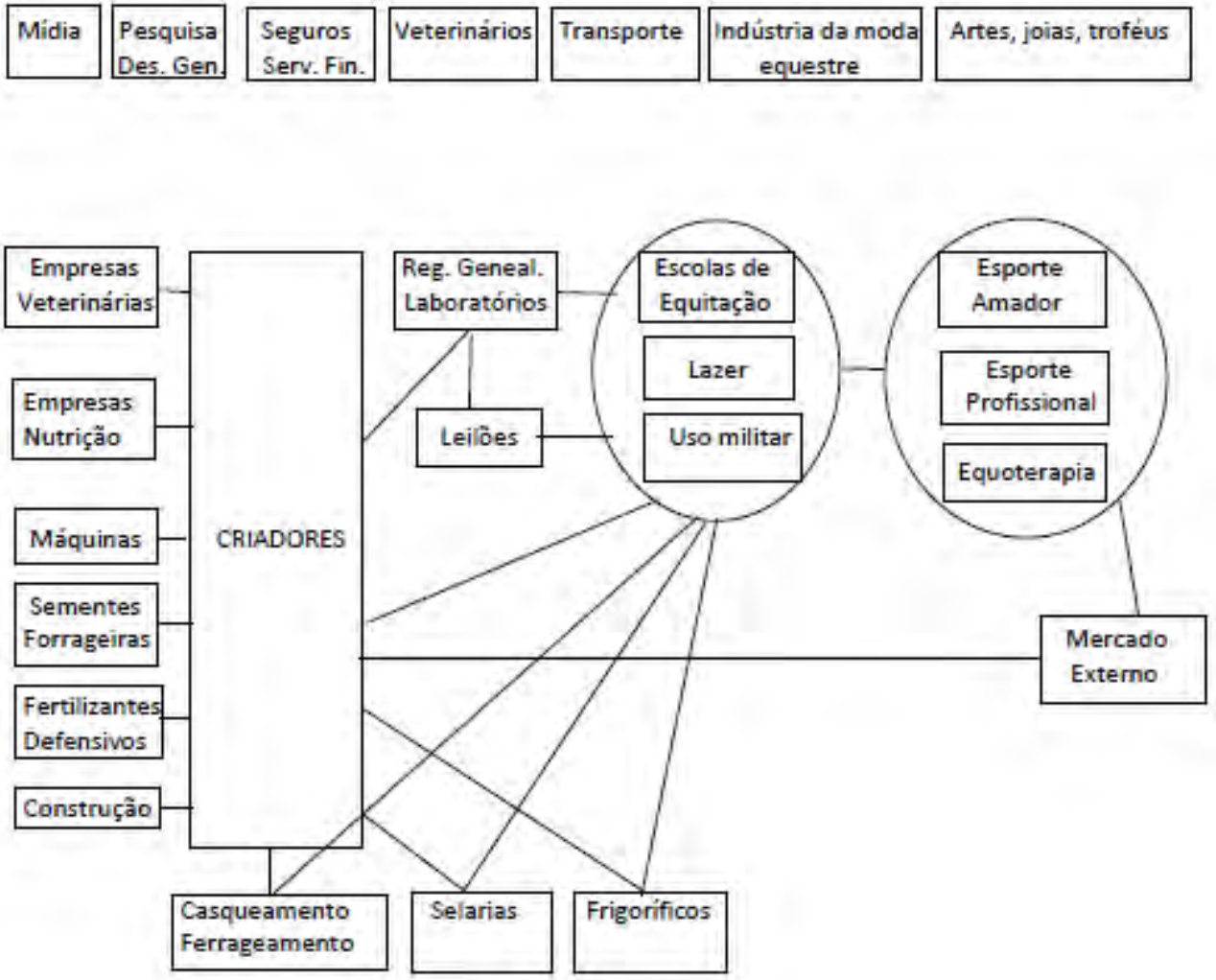

Fonte: adaptado de LIMA, SHIROTA \& BARROS (2006).

Ao estudar o desenho da cadeia da indústria do cavalo brasileira, a partir e adaptação do Estudo do Complexo do Agronegócio Cavalo (LIMA; SHIROTA, BARROS, 2006), evidenciou-se sua organização e estruturação.

Pode-se verificar que a cadeia é bem estruturada, apesar de a raça ser considerada relativamente nova no mercado. As empresas à esquerda (ração, sementes, etc.) dão condições de criação de equinos aos criadores, os quais recebem apoio como serviço de terceiros de ferradores e veterinários. Os criadores por sua vez, movimentam o mercado dos leiloes, laboratórios, competições, etc., oferecendo os animais para movimentar este mercado que gerará a possibilidade de realização de atividades militares de esporte e lazer, as quais atenderão tanto o mercado interno como o externo.

O papel da $\mathrm{ABCCH}$, responsável pelos registros genealógicos dos animais, é a manutenção do stud book da raça, dentre outros. De acordo com Navajas (2014), nos seis leilões realizados pela $\mathrm{ABCCH}$, contendo animais de alguns dos criadores da raça, entre agosto de 2013 e agosto de 2014, a média aproximada de preços dos animais foi de $\mathrm{R} \$ 18.000$ para animais de um ano; $\mathrm{R} \$ 25.000$ para animais de dois anos; $\mathrm{R} \$ 30.000$ para animais de três anos 
e R \$ 40.000 para animais de quatro anos ${ }^{20}$. O crescente valor observado nos animais reforça a citação anterior de valorização do animal com o passar dos anos e com a melhoria de sua condição atlética

\subsection{A DEMANDA}

Foram entrevistadas 23 pessoas físicas e 2 pessoas jurídicas. Considerando-se os usuários de equinos de hipismo, observou-se a distribuição de renda familiar apresentada na Figura 5 e a distribuição de renda pessoal na Figura 6.

Figura 5 - Distribuição da frequência dos entrevistados por faixa de renda familiar (Número de respostas: 18$)$.

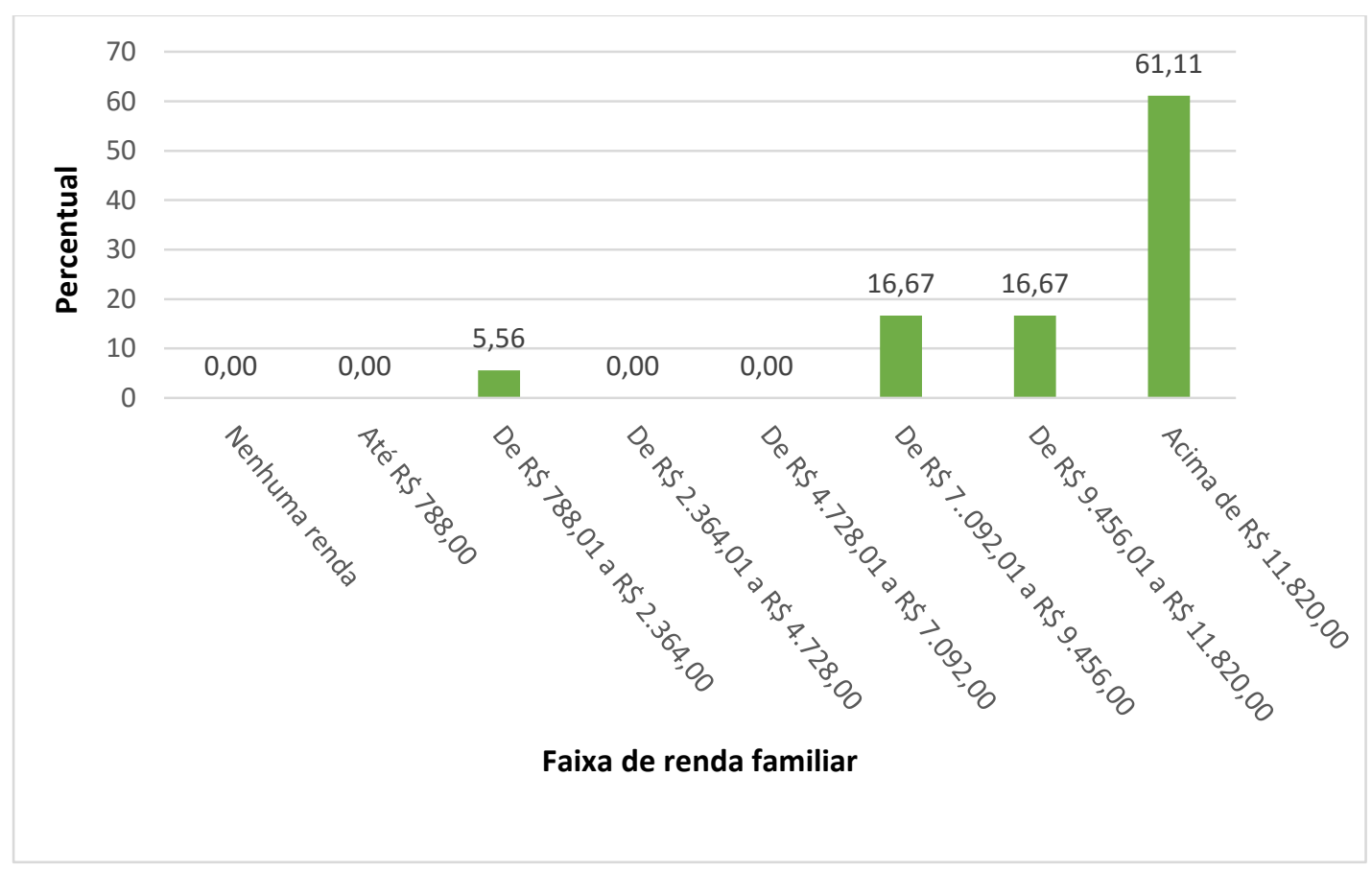

Fonte: Própria autoria.

Para se ter uma referência, apresenta-se a classificação da renda utilizada pela Associação Brasileira de Empresas de Pesquisa (ABEP) no Quadro 3.

\footnotetext{
${ }^{20}$ NAVAJAS, M. Informações sobre a criação de cavalos da raça Brasileiro de Hipismo. Mensagem recebida por marcelo@sporthorses.com.br em 26 ago. 2014.
} 
Quadro 3 - Renda média domiciliar das classes sociais no Brasil no ano de 2015, em R\$.

\begin{tabular}{|c|c|}
\hline Classe social & Renda média domiciliar \\
\hline A & $20.272,56$ \\
\hline B 1 & $8.695,88$ \\
\hline B 2 & $4.427,36$ \\
\hline C1 & $2.409,01$ \\
\hline C2 & $1.446,24$ \\
\hline D $-\mathrm{E}$ & 639,78 \\
\hline
\end{tabular}

Fonte: ABEP, 2015.

Figura 6 - Distribuição da frequência dos entrevistados por faixa de renda (Número de respostas: 21 )

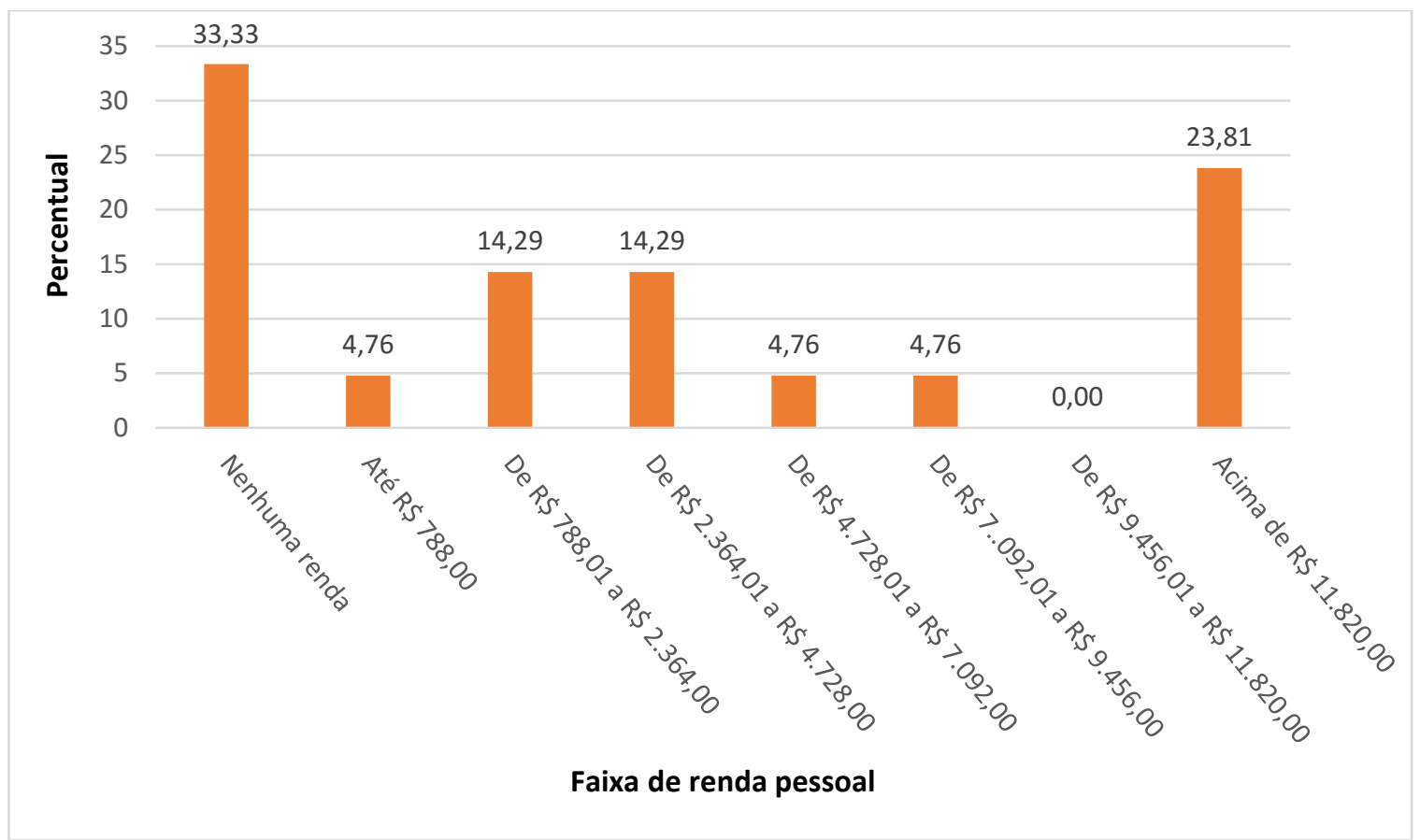

Fonte: Própria autoria.

$\mathrm{Na}$ figura acima, são apresentadas as faixas de renda ou faturamento dos entrevistados. Verificou-se que $33,33 \%$ dos entrevistados não possuem renda, fato explicado por se tratarem de estudantes; e 23,81\% possuem renda superior a $\mathrm{R} \$ 11.820$.

Dentre os entrevistados (Figura 7), a maioria foi representada por estudantes (que não apresentavam renda), seguida de veterinários, cavaleiros e empresários, o que pode levar à distribuição percentual de renda apresentada anteriormente. 
Figura 7 - Distribuição da frequência de profissões observadas nos entrevistados (Número de respondentes: 24$)$.

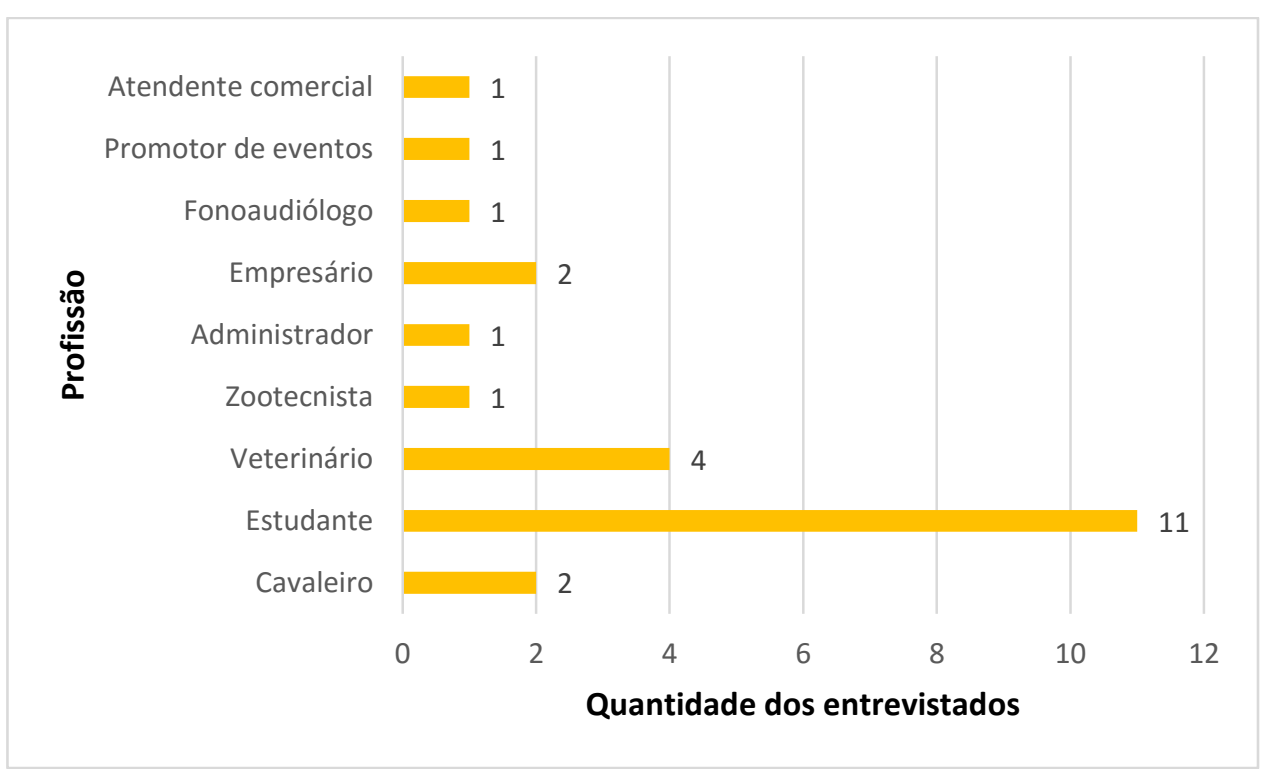

Fonte: Própria autoria.

Quando se relaciona a idade dos entrevistados (Figura 8), observa-se que a maioria é menor que 41 anos e as maiores concentrações das entrevistas atingiram as faixas de 9 a 14 e de 21 a 27. Outra informação importante observada é que o hipismo é um esporte que atinge todas as faixas etárias diferentes de muitos esportes que são praticados apenas por jovens. Dessa forma, o hipismo pode ser considerado um esporte de família. 
Figura 8 - Distribuição da frequência dos entrevistados por idade (Número de respondentes: 23).

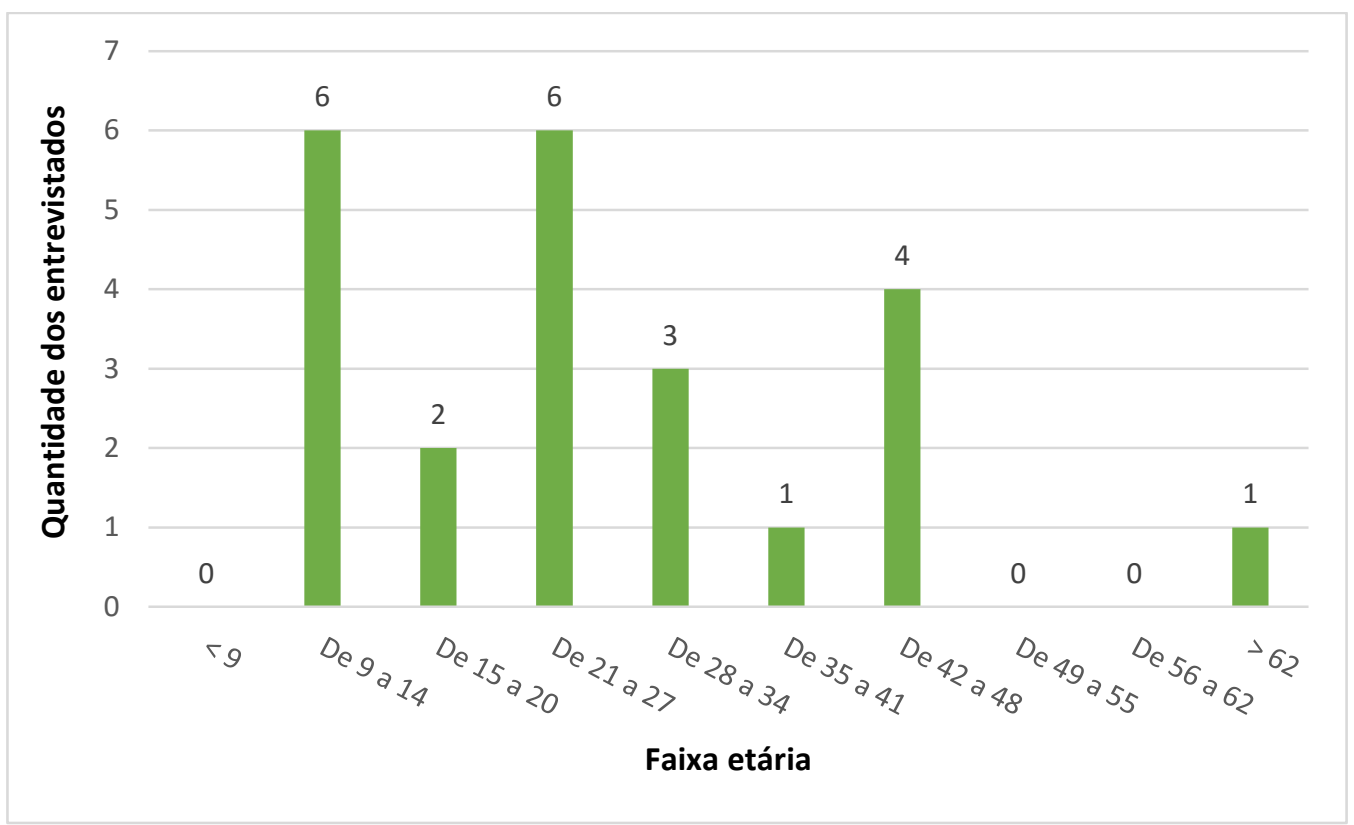

Fonte: Própria autoria.

Os cavalos são alojados em sua maioria próximos aos grandes centros e à residência dos proprietários, evidenciado pela maior distribuição dos alojamentos em hípicas, seguidos de haras. A estrutura das hípicas favorece o convívio entre os participantes do esporte e suas famílias, além de oferecer momentos de lazer, pois neste espaço podem ocorrer competições equestres. Por conta dessas facilidades oferecidas pelas hípicas, a maioria dos animais é alojada nelas. 
Figura 9 - Percentual de proprietários em função do local onde mantém seus animais (número de respondentes: 25$)$.

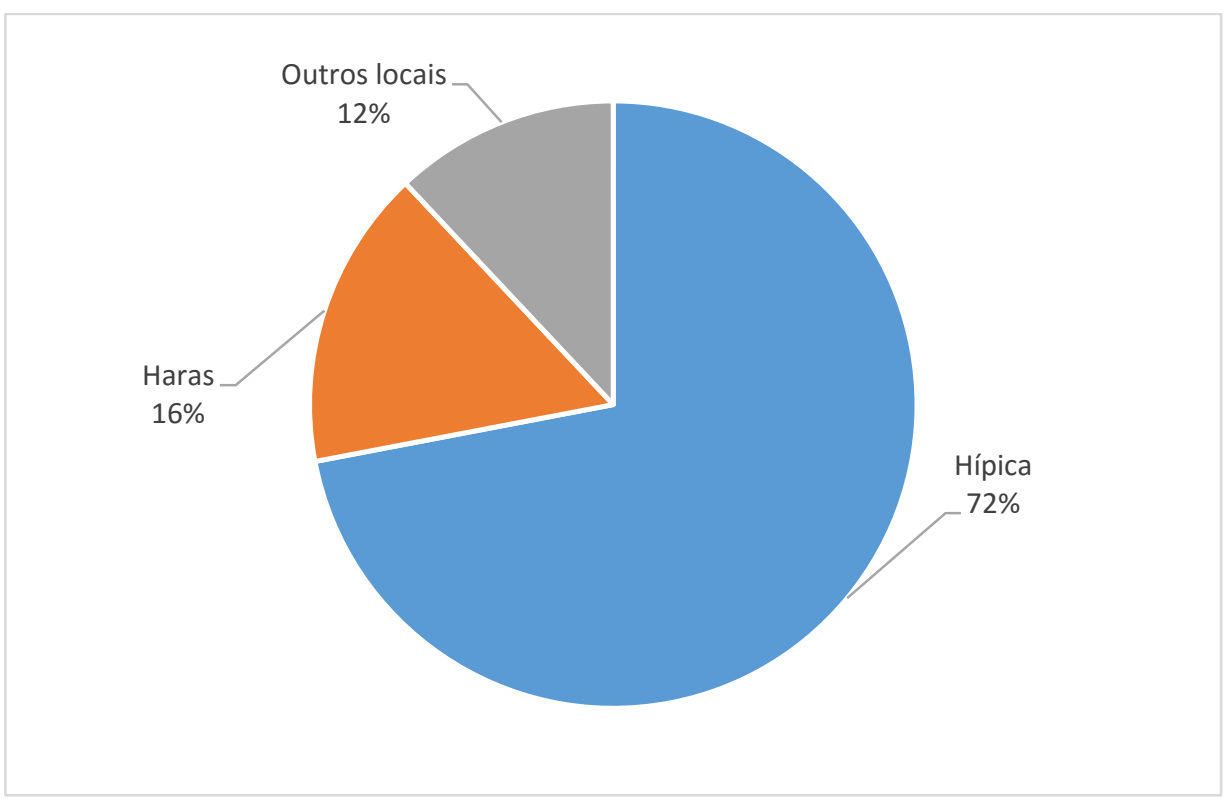

Fonte: Própria autoria.

O maior número de jovens entrevistados somados aos proprietários, indica a predominância de amadores no esporte. Além disso, os amadores buscam no esporte hípico atividades de esporte e lazer, confirmando a concentração em centros hípicos bem estruturado. Além disso, os animais precisam estar concentrados no treinamento, e as hípicas proporcionam o ambiente ideal para que os animais se mantenham focados. Os profissionais que responderam ao questionário correspondem aos prestadores de serviço da atividade (Figura 10). 
Figura 10 - Distribuição da frequência dos entrevistados por classificação (Número de respondentes: 24$)$.

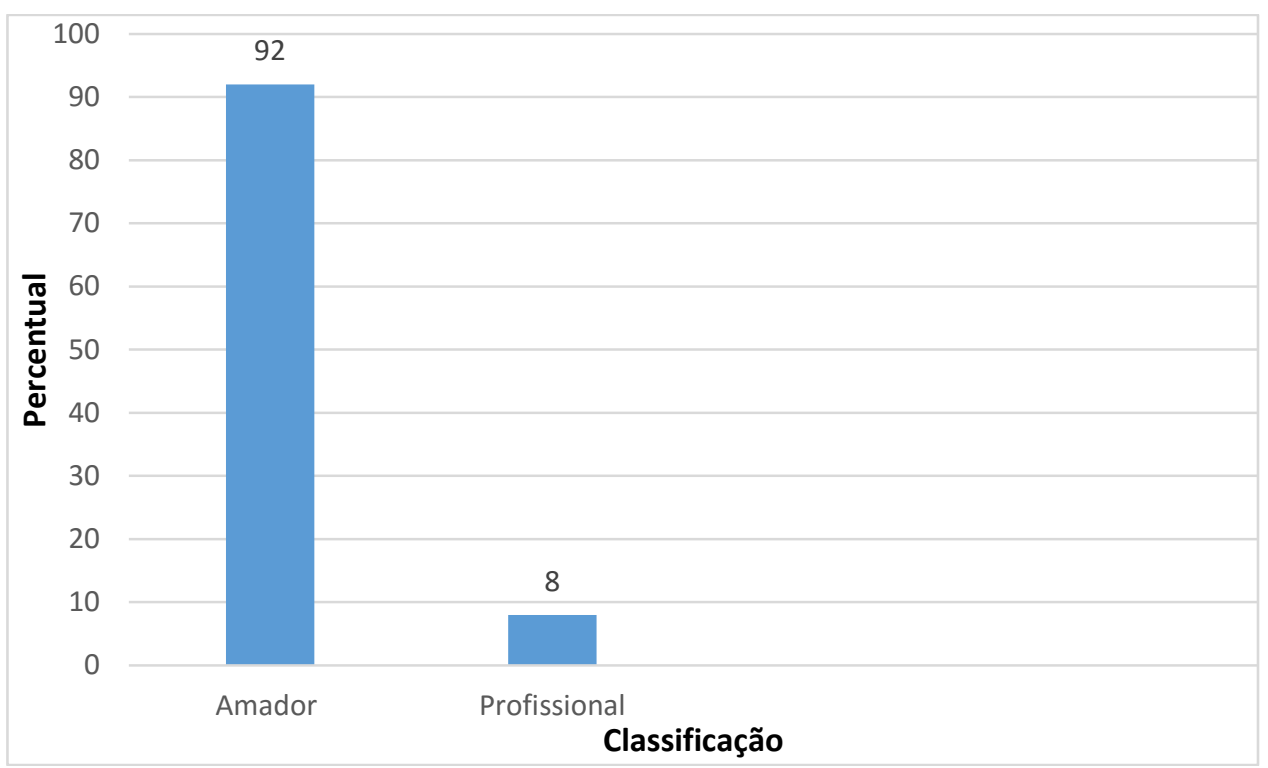

Fonte: Própria autoria.

Ao questionar o que o cavalo representava para cada um dos entrevistados, observouse que a $62,16 \%$ dos entrevistados consideram os cavalos como "membros da família" e apenas $21,62 \%$ consideram o cavalo como profissão. Para esta questão, o respondente poderia assinalar mais de uma opção. Este resultado pode refletir o público que participou das pesquisas (amadores do esporte) e indicar que o cavalo está sendo considerado animal de estimação para as famílias e com isso terá valor sentimental associado ao comercial. 
Figura 11 - Distribuição da frequência $(\%)$ das respostas à pergunta sobre o que representa o cavalo para os respondentes (Número de respostas: 41 ).

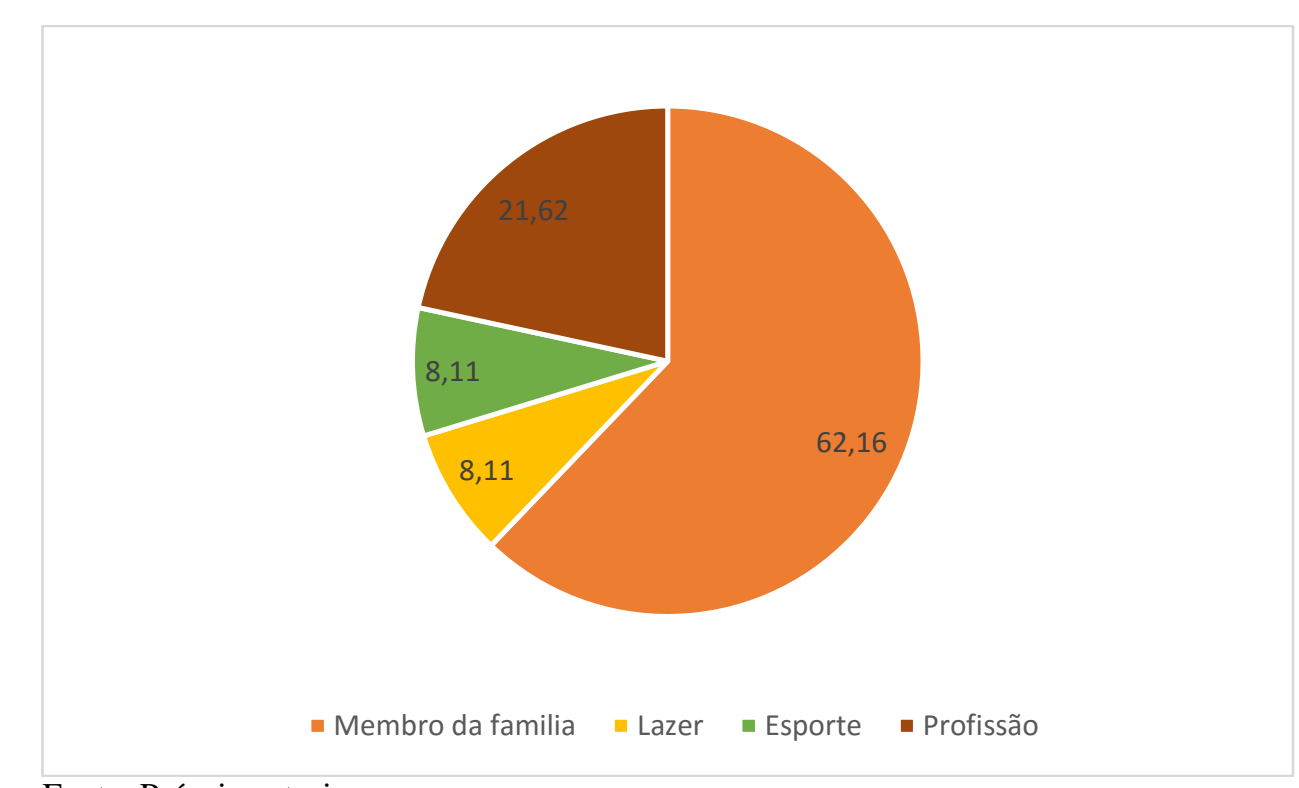

Fonte: Própria autoria.

Ao se observar o número de vezes que o proprietário interage com o cavalo ao longo da semana (Figura 12), nota-se que a maioria dos animais é utilizado todos os dias, o que pode refletir uma atividade de lazer e esporte para proprietários e a intensidade de uso dos cavalos nos centros de treinamento (hípicas). Além do mais, o hipismo exige muito treino do conjunto. Se o animal não for exercitado constantemente não apresenta bom desempenho nas competições. 
Figura 12 - Distribuição da frequência dos entrevistados por frequência de uso do animal na semana (Número de respostas: 23).

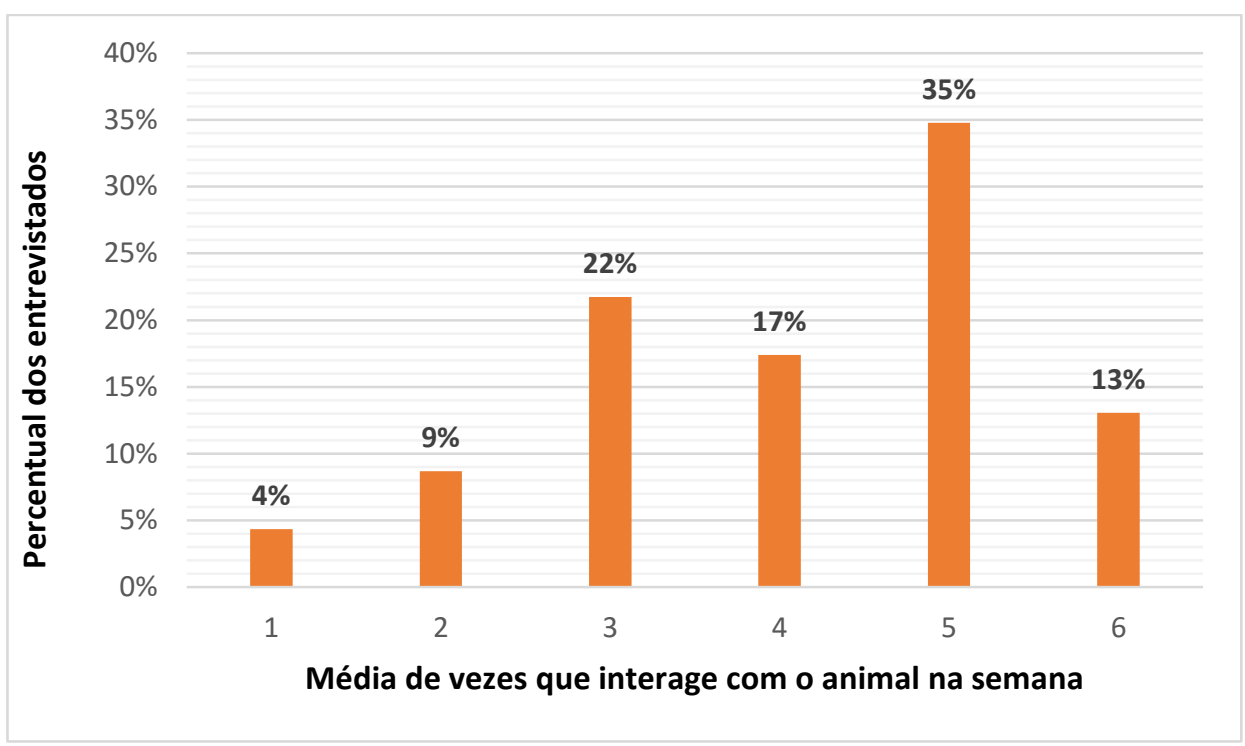

Fonte: Própria autoria.

Observou-se $64 \%$ dos proprietários buscavam outras atividades esportivas.

Quando questionados sobre a motivação para a realização do esporte (Figura 13), observou-se prevalência de respostas das pessoas que simplesmente gostavam de cavalo (demostrando viés de animais de companhia), bem como atividade que aliviava o estresse.

Figura 13 - Distribuição de frequência das respostas sobre os motivadores à prática do hipismo (Número de respondentes: 25).

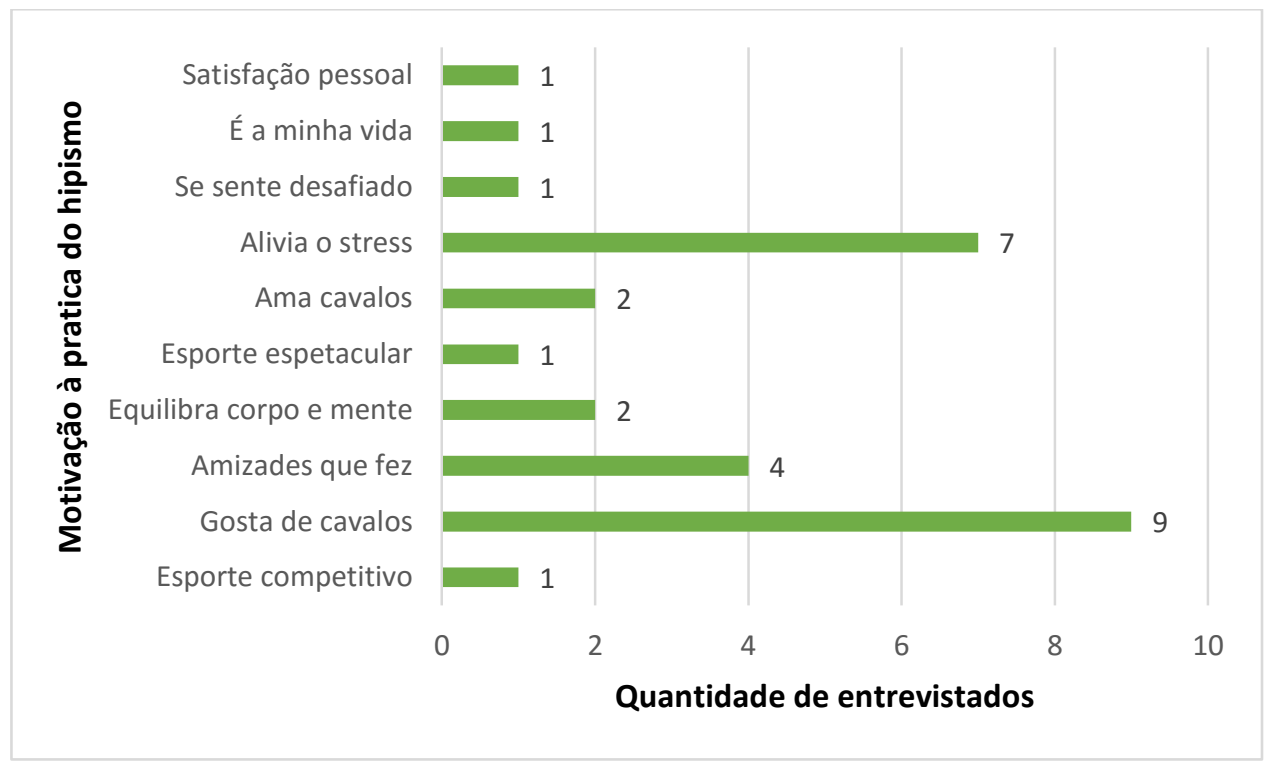

Fonte: Própria autoria. 
Em relação à prática de outros esportes, pelos entrevistados, obteve-se o resultado apresentado na Figura 14.

Figura 14 - Distribuição da frequência dos entrevistados por algum outro esporte praticado (Número de respostas: 16).

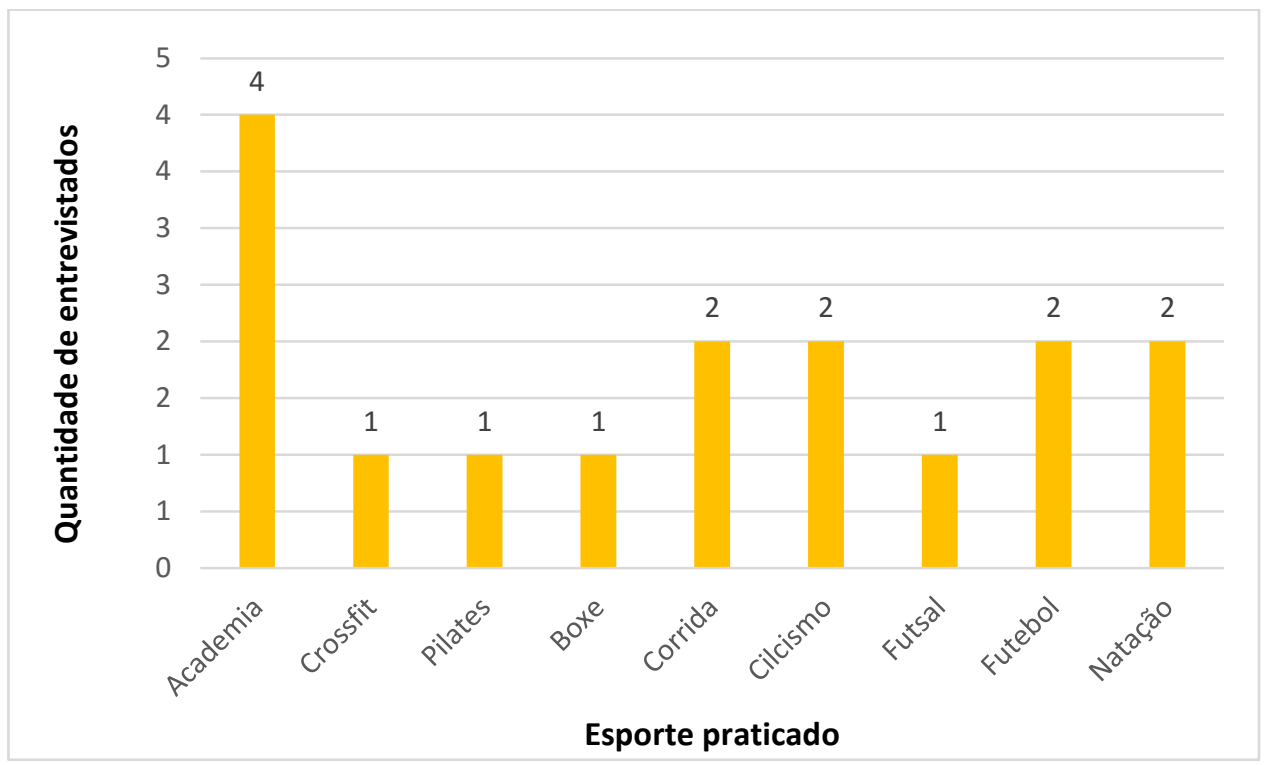

Fonte: Própria autoria.

Quando se considerou a modalidade praticada pelo ginete, deve-se considerar a situação na qual ocorreu a aplicação dos questionários (Figura 15). A região analisada (Ribeirão Preto e Pirassununga, além de alguns praticantes que responderam pela internet, tendo sua localização variada) apresenta grande número de propriedades envolvidas em CCE e salto, o que provavelmente pode ter influenciado os resultados. Além disso a região diz respeito à área de maior atuação da Associação Brasileira dos Praticantes do Hipismo Rural (ABHIR), entidade que organiza as provas da modalidade. Finalmente, deve-se considerar que o cavalo $\mathrm{BH}$ é indicado primordialmente às modalidades de salto, CCE e adestramento.

A escolha das duas escolas de equitação praticantes de CCE, para a realização das entrevistas, pode também ter influenciado os resultados. O Centro Hípico Pagoto e o Centro Hípico Guega são importantes polos do CCE nacional. 
Figura 15 - Distribuição da frequência dos proprietários ou praticantes de hipismo por modalidade equestre (número de respostas: 27).

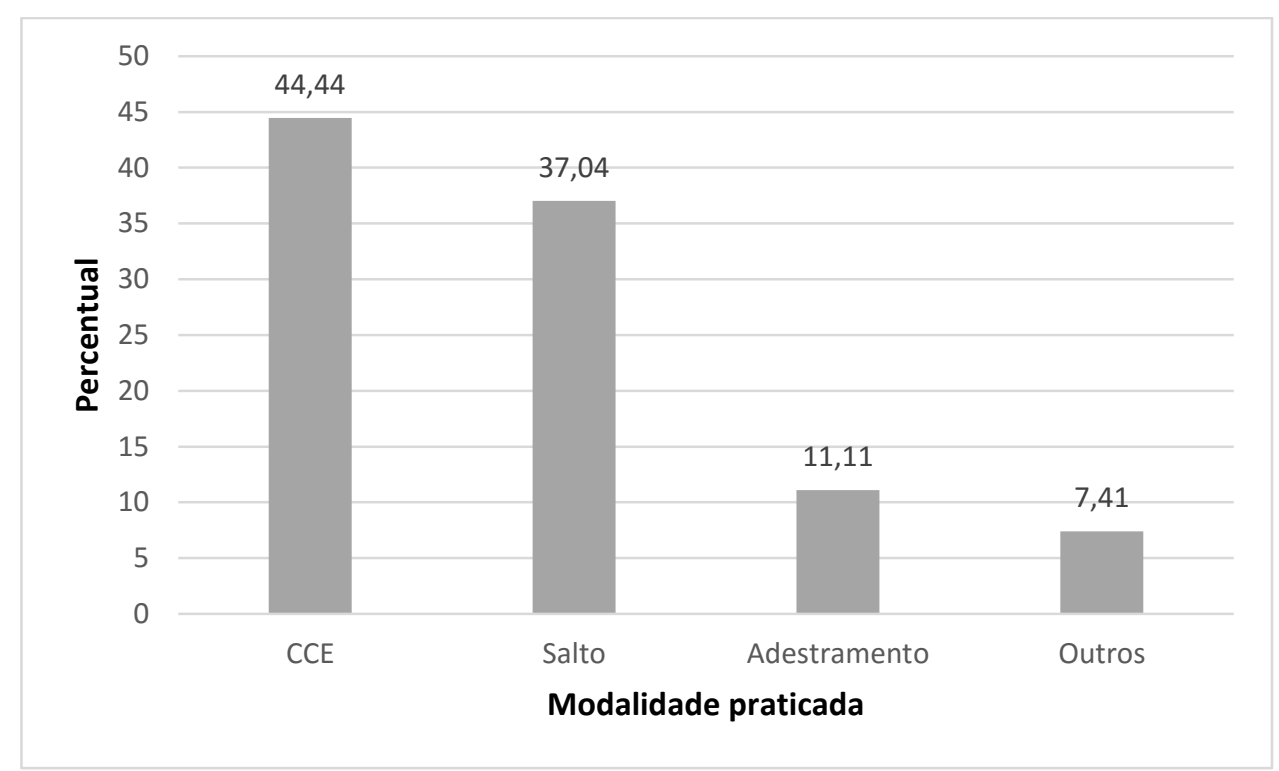

Fonte: Própria autoria.

No que se refere à quantidade de animais que cada pessoa entrevistada possui, os resultados são mostrados na figura a seguir.

Figura 16 - Quantidade de animais de posse (Número de respondentes: 25).

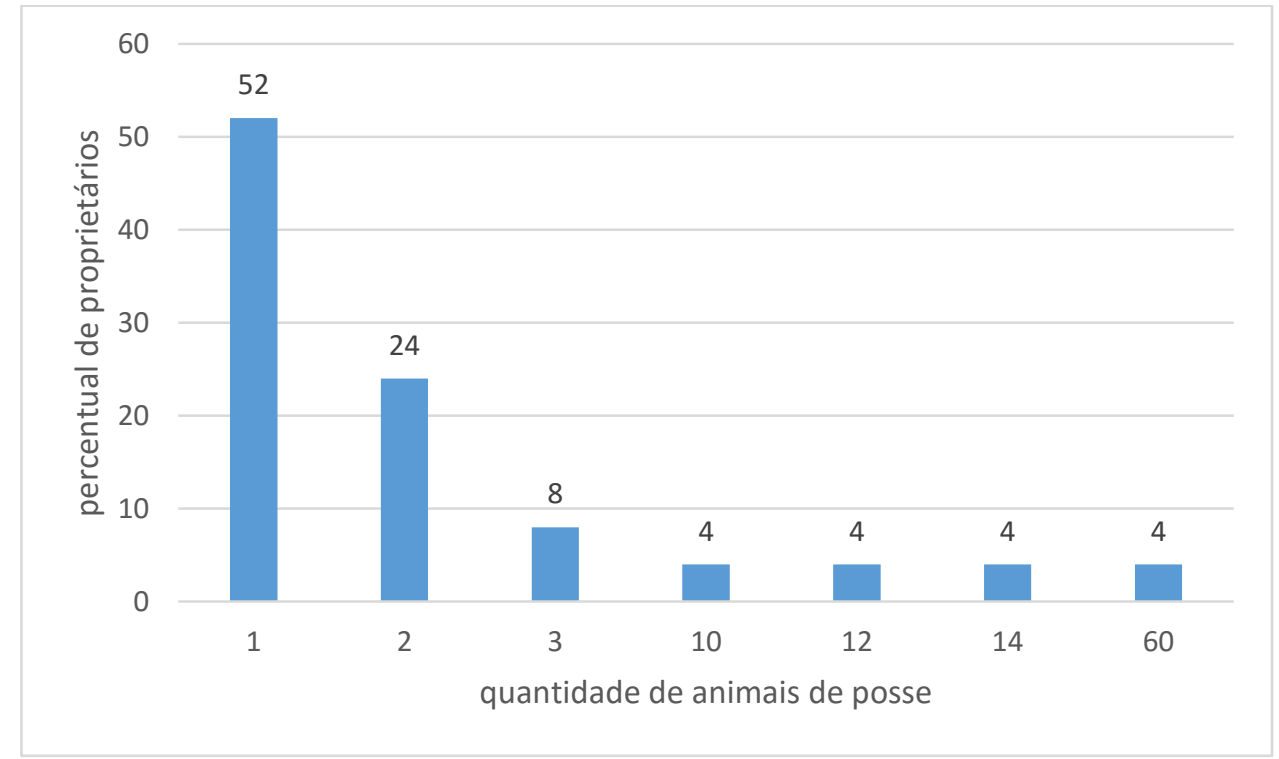

Fonte: Própria autoria.

Como o maior público entrevistado refere-se predominantemente a amadores, era esperado uma certa tendência de que cada proprietário possuiria apenas um ou dois animais. 
Ademais, o esporte apresenta custo relativamente elevado, quando se leva em consideração o custo de estabulagem e manutenção dos animais, além de custo com serviço de terceiros e as participações em eventos equestres. Outro custo especifico dos animais que apresentam registro é o passaporte, documento exigido para todos que participem de competições oficiais, normatizadas com as regras da CBH e da FEI. Para as categorias mais avançadas, é necessário trocar o selo deste passaporte anualmente, o que acarreta em cobrança de taxas. Para a participação dos eventos hípicos custos como transporte, diárias e estadia no local da competição também se fazem presentes.

Quando se consideram os proprietários que têm mais de um animal, sugere-se que esta escolha tenha sido feita para aumentar suas chances nas competições, mesmo com o aumento de custo relativo do esporte.

Por outro lado, ao se analisar o número de pessoas que utiliza o mesmo animal, observou-se que 58,33\% dos animais são utilizados somente por uma pessoa. Em seguida vêm os animais utilizados por duas pessoas, o que representa $29,17 \%$ do total de animais. Vale ressaltar que na maioria dos casos em que os animais são montados por duas pessoas, eles são utilizados pelo proprietário e por um treinador, remunerado pelo proprietário para montar os animais para aperfeiçoamento. A porcentagem de cavalos que são montados somente pelo dono e os cavalos montados pelo dono mais um profissional do hipismo corresponde à maioria dos dados obtidos, representados por $87,5 \%$ do total de animais. Os animais utilizados nas escolas de equitação foram representados pelos maiores valores observados. 
Figura 17 - Distribuição da frequência por quantidade de pessoas que utilizam um animal (Número de respostas: 26).

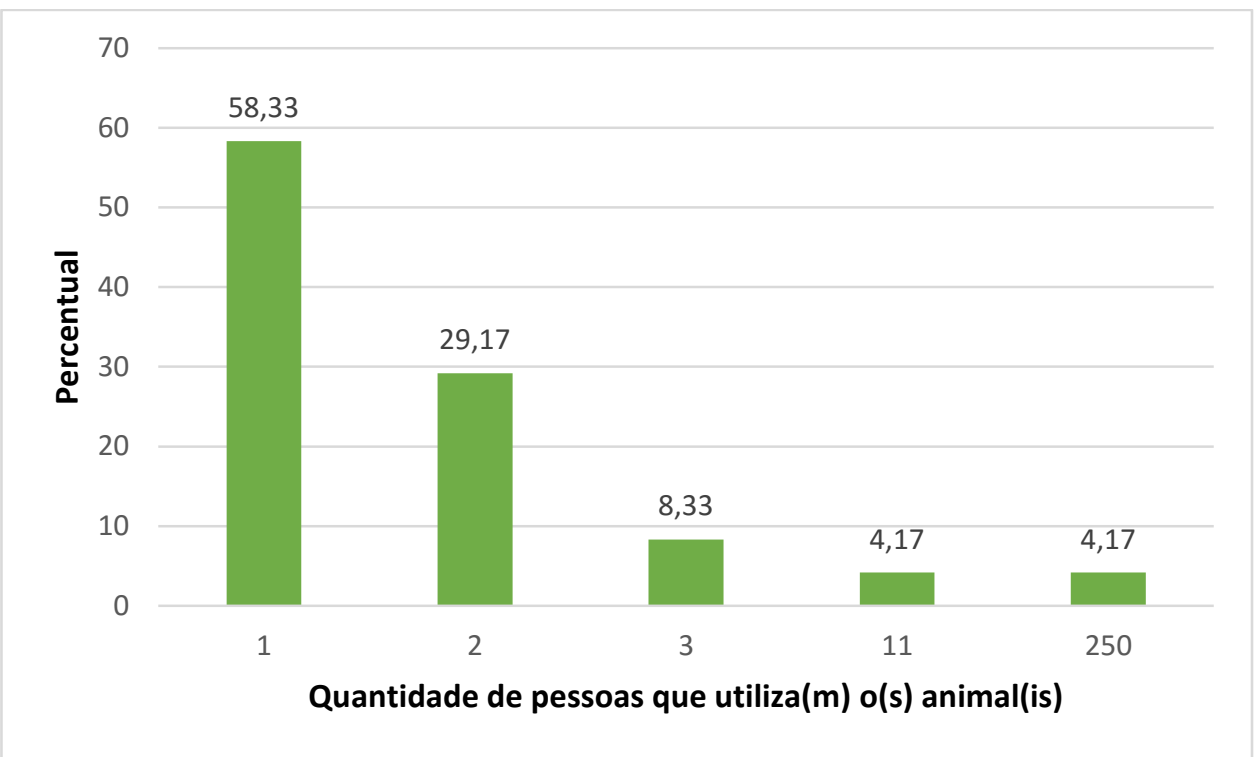

Fonte: Própria autoria.

Influenciados pelo local de realização do esporte hípico, 62,16\% do total dos entrevistados utiliza do cavalo para este esporte, seguido dos animais em treinamento, com 21,62\%. Os animais utilizados para nas escolas de equitação muitas vezes participam de competições desses alunos.

Figura 18 - Percentual por finalidade do uso dos animais pesquisados (Número de respostas: $37)$.

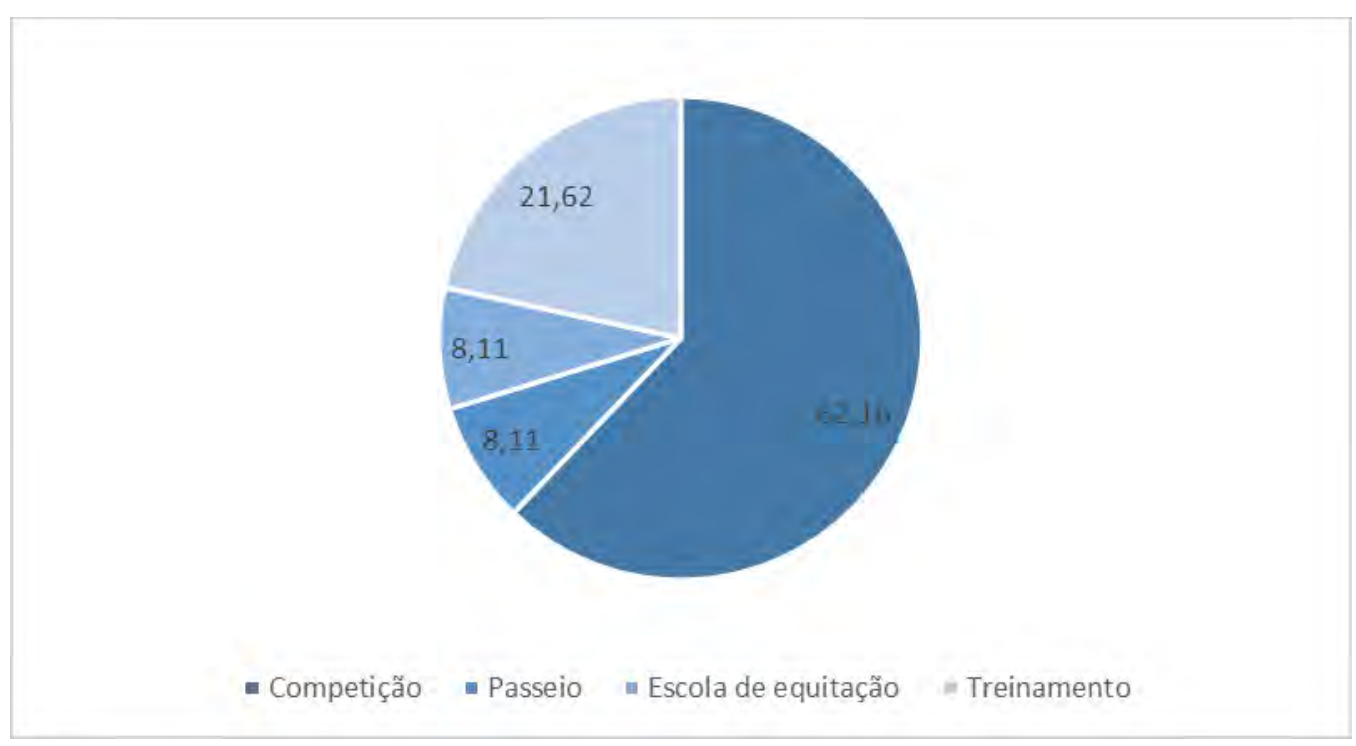

Fonte: Própria autoria. 
Como o público entrevistado estava vinculado ao CCE e salto no interior do estado de São Paulo, observou-se que $60 \%$ dos proprietários possuem animais da raça $\mathrm{BH}$ e $40 \%$ dos respondentes possuem animais $\mathrm{BH}$ e de outras raças, ou somente animais de outras raças, reforçando o potencial desta raça na região estudada (Quadro 4).

Quadro 4 - Distribuição da frequência de animais de posse dos respondentes por raça e percentual de cada raça declarada (Número de animais declarados: 177).

\begin{tabular}{|l|c|c|}
\hline \multicolumn{1}{|c|}{ Raça } & Número de animais & Percentual de cavalos da raça \\
\hline Sem raça definida & 65 & $37 \%$ \\
\hline BH & 62 & $35 \%$ \\
\hline Anglo Árabe & 31 & $18 \%$ \\
\hline PSI & 6 & $3 \%$ \\
\hline Mangalarga & 5 & $3 \%$ \\
\hline Quarto de Milha & 2 & $1 \%$ \\
\hline Lusitano & 2 & $1 \%$ \\
\hline Paint Horse & 1 & $1 \%$ \\
\hline Oldenburgo & 1 & $1 \%$ \\
\hline Sela Argentina & 1 & $1 \%$ \\
\hline Andaluz Brasileiro & 1 & $1 \%$ \\
\hline Total & $\mathbf{1 7 7}$ & $\mathbf{1 0 0 \%}$ \\
\hline
\end{tabular}

Fonte: Própria autoria.

Os animais sem raça definida são a maioria, com 37\% do total, seguidos pelos animais da raça $\mathrm{BH}$, com $35 \%$ do total. Os animais sem raça definida são utilizados, principalmente, nas escolas de equitação, local alvo das entrevistas. Em seguida, tem-se a raça Brasileiro de Hipismo. Depois da BH, é interessante observar a prevalência de cavalos da raça Anglo Árabe, pois esta raça é utilizada no hipismo rural, uma das principais modalidades organizadas pela ABHIR, o que pode ter influenciado neste elevado número. As demais raças presentes também podem ser utilizadas para CCE ou estão relacionadas com trabalho em fazendas, animais de lida ou ainda animais de passeio (Mangalarga, Quarto de Milha, Paint Horse).

Para a aquisição de animais, alguns fatores motivam a compra como a qualidade, a saúde, a versatilidade e o resultado em competições (Figura 19). O entrevistado poderia escolher mais de uma opção de motivação da compra do animal. 
Figura 19 - Distribuição da frequência dos fatores que motivaram a compra dos animais (Número de respostas: 42).

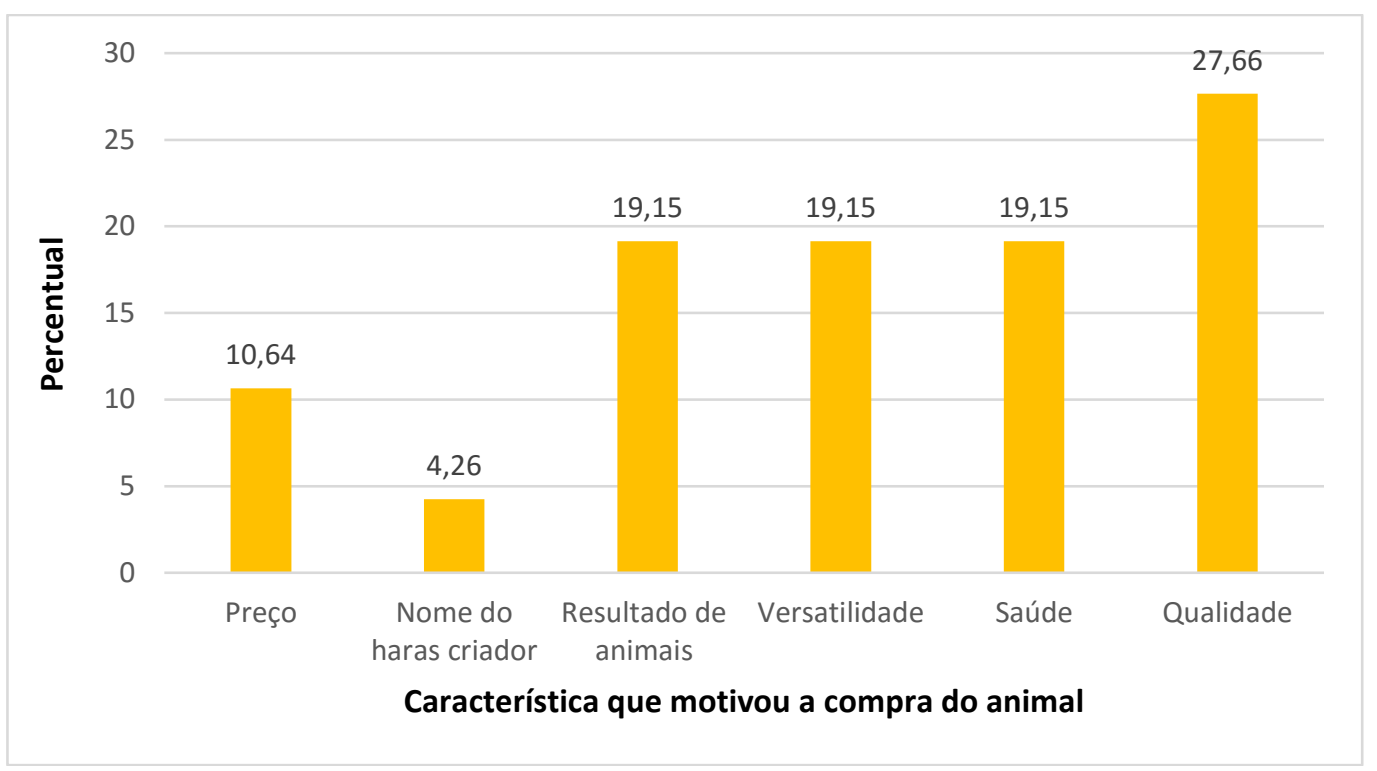

Fonte: Própria autoria.

Como pode-se verificar na figura acima, em $27,66 \%$ das respostas, o fator levado em consideração no momento da compra foi a qualidade do animal. Fatores com resultados dos animais da linhagem em competições, versatilidade e saúde do animal aparecerem em seguida, todos com $19,15 \%$ do total das respostas.

As qualidades enfatizadas são reflexo da finalidade do uso dos animais, que em sua maioria é para competição, situação que valoriza a saúde do animal para que seja possível a apresentação de suas características de qualidade, reforçando dados já apresentados de valorização dos animais ao longo de sua carreira hípica. A compra não foi feita, em sua maioria, levando em consideração o preço mais atrativo, e sim outros atributos dos animais em questão, como qualidade e saúde. Tais informações corroboram a premissa de que o mercado de cavalos da raça se trata de concorrência monopolística: pelo fato de haver diferenciação dos animais de acordo com o haras criador, os criadores têm certo poder de monopólio, mesmo havendo, neste mercado, grande número de criadores, como discutido anteriormente.

Verificando-se quais os fatores levaram à compra dos animais observou-se que a qualidade do referido animal foi o mais apontado pelos demandantes do cavalo. Pode-se, neste sentido, citar o estudo de Akerlof (1970), referente ao mercado de carros usados, em que existia grande possibilidade de o comprador acabar adquirindo um carro de má qualidade (chamado pelo autor de "limão"). Em analogia ao mercado de carros usados, existe a grande possibilidade de o demandante do cavalo $\mathrm{BH}$ adquirir um animal de qualidade inferior ao que realmente gostaria, uma vez que a assimetria de informação deste mercado é muito grande. Em geral, os 
ofertantes dos cavalos possuem maiores informações sobre o produto que estão oferecendo no mercado. O comprador correria o risco de acabar adquirindo um "limão". Uma característica interessante do mercado de cavalos é o fato de que, em grande parte das revendas dos animais, o seu preço é mais alto que o preço inicial, por conta do desenvolvimento e treinamento ao qual o animal é submetido com o passar do tempo. Essa diferença no preço inicial e futuro pode propiciar a arbitragem (no caso da compra do animal para investimento).

Ao analisar-se os valores investidos mensalmente em aulas e treinamento (Figura 20), observou-se que a maioria dos entrevistados têm investimento inferiores a $\mathrm{R} \$ 1.000$ o que pode refletir o público de escolas de equitação, onde o custo por animal é reduzido e o amadorismo dos participantes na atividade equestre, pois a medida que se desenvolvem na atividade são necessários maiores investimentos em treinamento, acarretando em maior custo (como é o caso de um profissional que dispende $\mathrm{R} \$ 5.000$ mensais com aulas e treinamentos).

Figura 20 - Distribuição da frequência dos respondentes por média mensal dispendido em aulas e/ou treinamentos (Número de respondentes: 21).

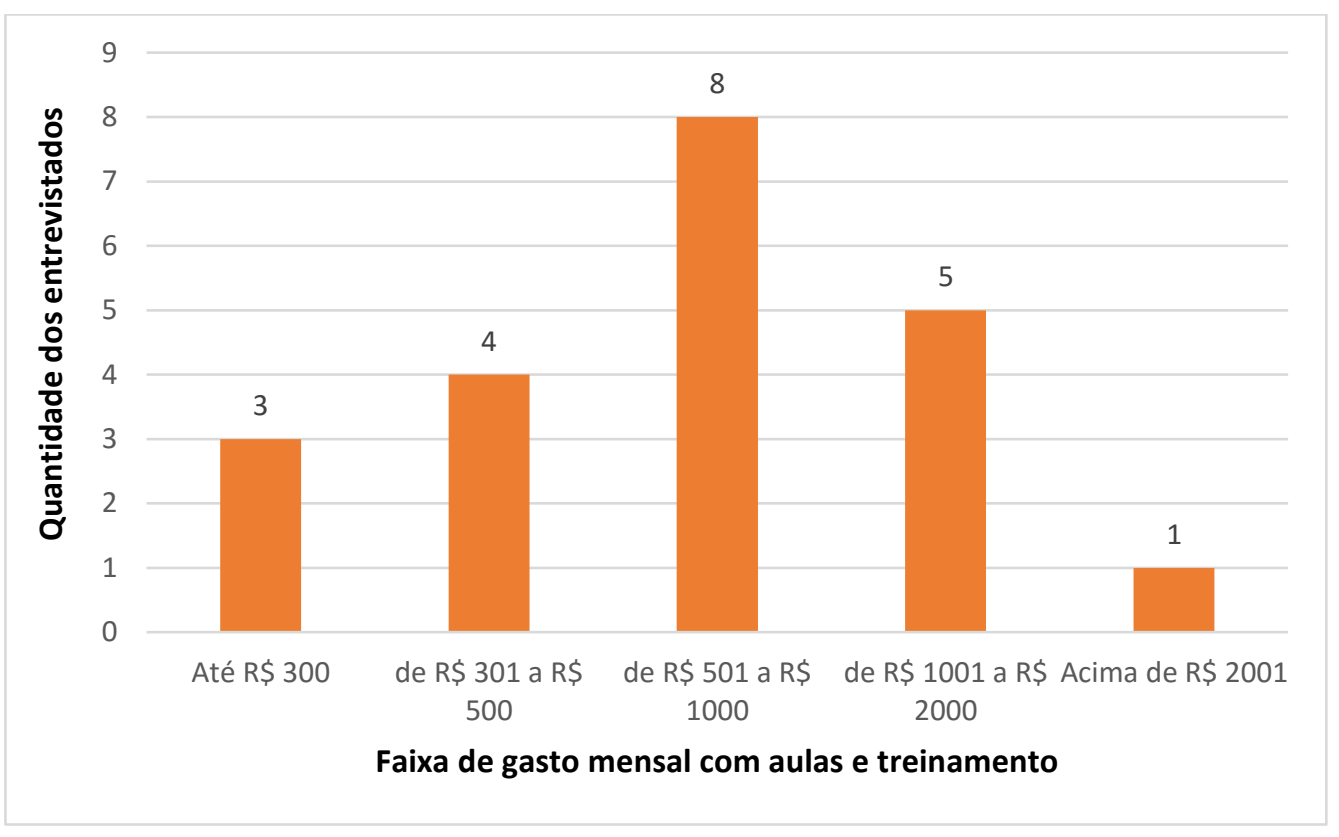

Fonte: Própria autoria.

Quando se considera o valor de estabulagem dos animais, observou-se a influência do local de entrevista, uma vez que a maioria foram realizadas em um haras onde o valor de estabulagem está próximo a $\mathrm{R} \$ 1.500,00 / \mathrm{mês}$, o que refletiu também nas respostas observadas para gastos com alimentação, uma vez que neste citado local o valor de alimentação já estava incluso no valor da estabulagem (Figura 21). 
Figura 21 - Custo médio mensal com estabulagem de um animal (Número de respondentes: 21)

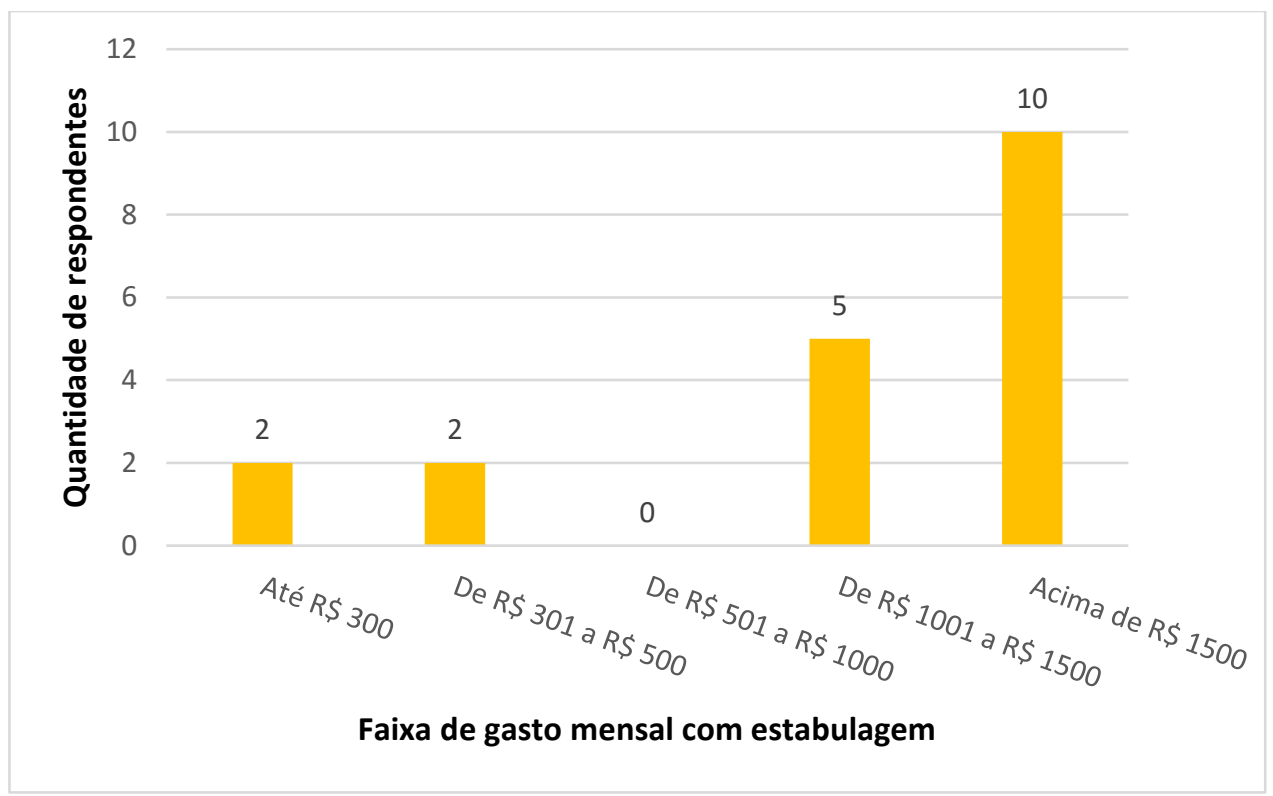

Fonte: Própria autoria.

Figura 22 - Distribuição da frequência por média mensal gasta com alimentação (Número de respondentes: 21 )

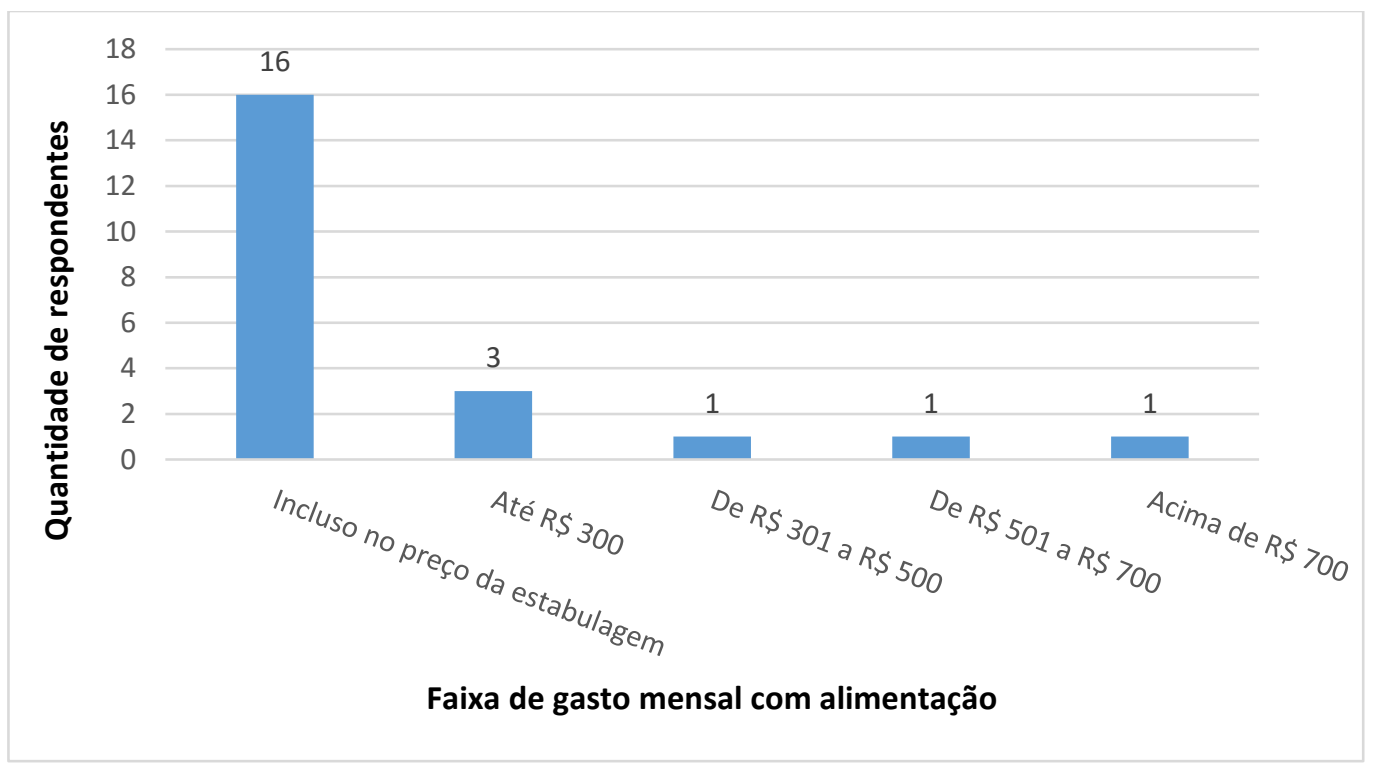

Fonte: Própria autoria.

Ao se calcular o custo médio mensal de manutenção de um animal obteve-se valor de $\mathrm{R}$ \$ 2.587,80, sem considerar custos com veterinários, fármacos, transporte e inscrições em órgãos responsáveis pela realização de competições, exames, entre outros. Como os animais foram comprados para uso pessoal (Figura 23), sugere-se forte viés como animais de estimação 
e, com isso, o custo da atividade se torna menos significativo, reforçado pelas respostas obtidas dos entrevistados, que declaram, em 100\% dos casos, não trocar o hipismo por nenhuma outra modalidade esportiva.

Figura 23 - Distribuição da frequência (\%) de respostas por finalidade da compra do cavalo (Número de respondentes: 24).

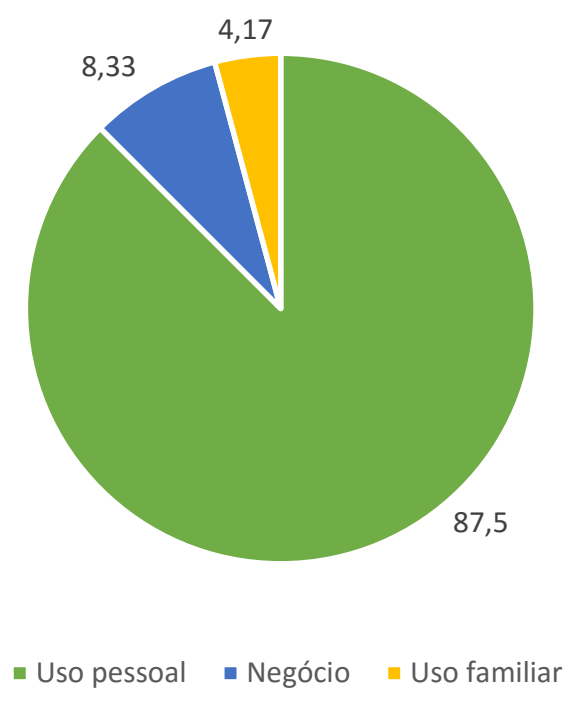

Fonte: Própria autoria.

Das pessoas que adquiriram os animais para negócio, metade têm expectativa de valorização dos animais de 50\% e a outra metade espera que seus animais valorizem em 100\% em relação ao preço pago pelo animal. Essa informação é condizente com aquela apresentada anteriormente, que sugere que o cavalo é um bem que tem seu preço de revenda, muitas vezes, mais alto que seu preço inicial, mesmo com o passar dos anos. Isto ocorre pelo fato de o cavalo se desenvolver com o passar dos anos, tornando-se conhecida sua saúde, sua trajetória em competições. Além do mais, se o mesmo ganhar as competições que participa, é mais valorizado no mercado.

Com relação às expectativas de mercado, pode-se verificar a percentagem das respostas de duas questões sobre o tema no quadro a seguir. 
Quadro 5 - Percentual de respondentes que mudaria sua compra de acordo com as expectativas vigentes no mercado (Número de respostas: 21)

\begin{tabular}{|l|c|c|}
\hline Pergunta & Sim & Não \\
\hline $\begin{array}{l}\text { Caso houvesse expectativa de aumento no preço do animal, anteciparia } \\
\text { a compra? }\end{array}$ & $84,21 \%$ & $15,79 \%$ \\
\hline Caso houvesse expectativa de queda no preço do animal, aguardaria? & $61,90 \%$ & $38,10 \%$ \\
\hline
\end{tabular}

Fonte: Própria autoria

Pode-se observar que as expectativas afetam a demanda de um bem ou serviço realmente procede, e que os demandantes dos cavalos de hipismo alterariam o momento de sua compra por conta de expectativas de mudanças no preço dos animais (Quadro 5). O percentual de pessoas que aguardaria para comprar o animal a um preço inferior é menor provavelmente pelo fato de os mesmos não saberem se o animal continuará com boa saúde no futuro. Além disso, a necessidade imediata de adquirir um novo animal também faz com que esse percentual seja menor: como a maioria dos respondentes utiliza seus animais para competir, alguns respondentes preferem pagar um preço mais alto, para poder adquirir o animal no presente. Tais informações também podem estar ligadas aos dados obtidos no que se refere à faixa de renda dos entrevistados: como a maior parte dos demandantes do cavalo $\mathrm{BH}$ possuem faixa de renda elevada, a necessidade de compra do animal pode fazer com que não se espere uma possível queda no preço do mesmo. Ademais, os dados sugerem que os entrevistados possuem noções do mercado de cavalos da raça.

O preço do animal depende muito da situação deste animal no mercado. O cavalo pode ter um valor inicial de $\mathrm{R} \$ 20.000$, porém, se competir em um final de semana e se tornar campeão do evento no qual participou, seu preço pode passar para $\mathrm{R} \$ 40.000$, por exemplo. Outra influência sobre o preço é a localização do animal, por conta do poder aquisitivo das pessoas residentes na cidade em questão. Um animal pode ser comprado a um preço mais baixo no interior do estado e ser vendido por um preço mais elevado na capital. Além do mais, as leis de oferta e procura exercem influência no preço do equino. Caso ele seja desejado por diversos demandantes o seu preço se torna mais elevado.

Ao se questionar os profissionais, observou-se influência de individuo, pois, o número de entrevistas foi pequeno (dois profissionais), o que levou a disparidade nos dados. Quando o profissional se dedica exclusivamente a atividade equestre, o número de cavalos trabalhados foi maior, cerca de 5 por dia. 
Com relação à raça dos animais trabalhados por estes dois profissionais, que são proprietários de escolas de equitação, o primeiro monta, em média, um cavalo da raça $\mathrm{BH}$ por dia e o segundo trabalha 3 cavalos $\mathrm{BH}$ por dia. Tal fato sugere, mais uma vez, como a raça em questão parece ter se consolidado no país. No caso do profissional que monta cinco cavalos por dia, três deles são da raça BH. Quando o entrevistado é profissional, os dados mostram que ele monta cavalos $\mathrm{BH}$, registrados, com objetivo de vende-los para amadores ou crianças, dependendo da idade do animal em questão.

\subsection{OFERTA}

Foram entrevistados seis criadores do BH. Quando se considera a produção de cavalos da raça Brasileiro de Hipismo, um dos pontos a serem destacados são as biotecnologias utilizadas na reprodução. Observou-se prevalência da inseminação artificial, técnica contemporânea e aceita pela associação da raça, seguida pela transferência de embriões, técnica mais moderna que agrega valor ao produto (Figura 24).

Figura 24 - Distribuição percentual das biotecnologias de reprodução utilizada pelos criadores (Número de respostas: 13)

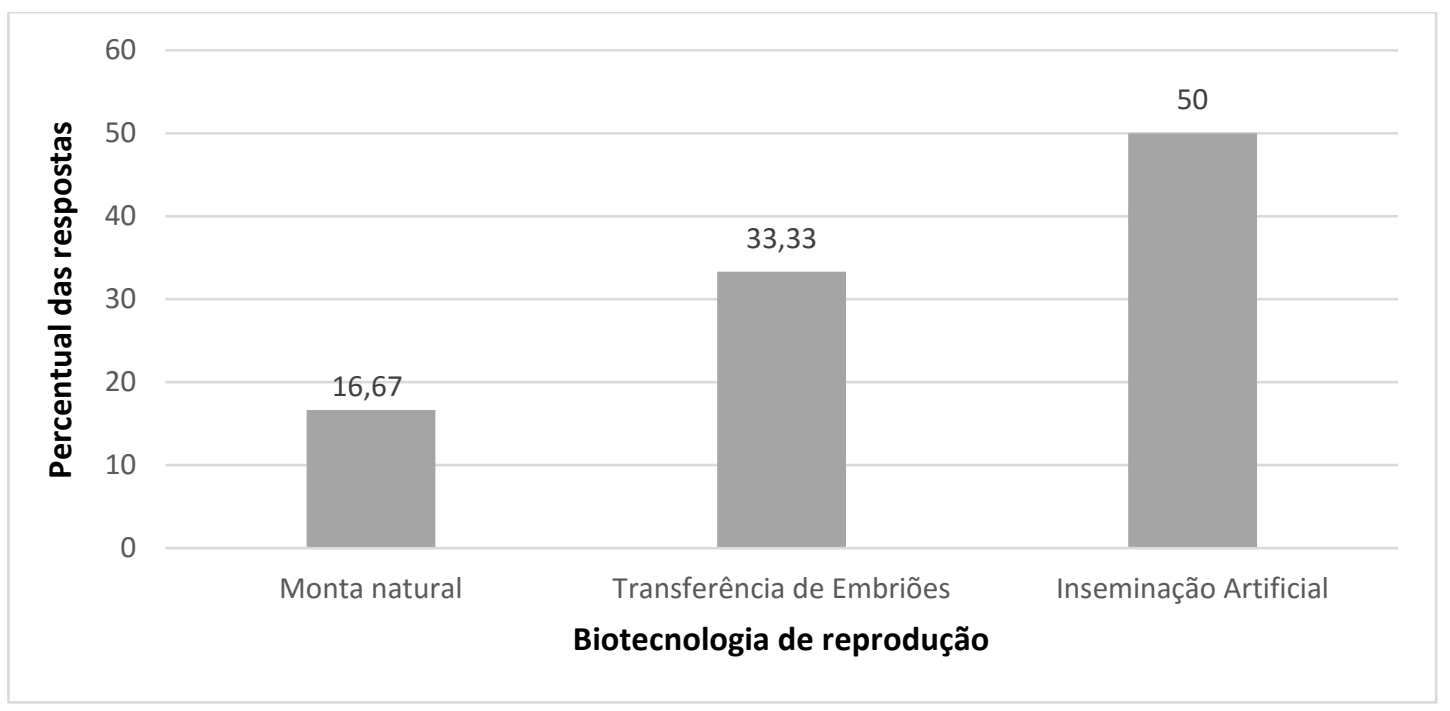

Fonte: Própria autoria.

A utilização dessas técnicas sugere maior comprometimento dos criadores quanto ao aperfeiçoamento genético animal. Comparando-se tais resultados com os da pesquisa de Vieira (2011), que estudou a criação do cavalo da raça Mangalarga no estado de Minas Gerais, observa-se que as taxas de utilização de IA (50\% contra 13,11\%) e TE $(33,33 \%$ contra $15,95 \%)$ 
são bem superiores. A taxa superior de uso da TE pode ser explicada, também, pelo fato de possibilitarem que os animais BH's continuem competindo.

Além disso, ao comparar-se os dados obtidos com o estudo de Grimes e Ray (1991), chegou-se à conclusão que a realidade dos criadores de equinos americanos e a realidade dos criadores do Cavalo Brasileiro de Hipismo é bastante semelhante no que se refere às técnicas de reprodução. Em ambos países se utiliza com frequência a inseminação artificial, com o intuito de buscar o melhoramento genético dos animais produzidos, oferecendo animais de qualidade e diferenciados no mercado. As associações de criadores, tanto as das raças americanas como a $\mathrm{ABCCH}$, foram estabelecidas por proprietários de haras criadores, com o intuito de fiscalizar e fortalecer a criação. O estudo de Grimes e Ray (1991) sugeriu ainda, que as associações de criadores eram responsáveis pelas fiscalizações dos stud books. O mesmo ocorre com a $\mathrm{ABCCH}$. Nesse contexto, a $\mathrm{ABCCH}$, responsável pela regulamentação e promoção da raça BH no Brasil, cumpre exatamente o papel identificando pelos autores nos Estados Unidos: manter a pureza e qualidade dos equinos produzidos, com o auxílio da manutenção do stud book; promover e fortalecer a raça no país.

Aldridge e Koenen (2002) verificaram que o objetivo dos criadores das raças de todo o mundo conhecidas como warmbloods era o de buscar o melhor desempenho dos animais produzidos nas três principais modalidades do esporte hípico (salto, adestramento e CCE), através do melhoramento genético dos animais, possibilitado com a utilização das tecnologias de reprodução, que permitem a utilização de sêmen de garanhões e óvulos de éguas mundialmente renomados (de algumas raças aprovadas pela $\mathrm{ABCCH}$, que são tidas como formadoras do Brasileiro de Hipismo). Isso foi também verificado na criação do Cavalo BH. Essa alta taxa de uso de IA e TE mostra a preocupação dos criadores da raça em promoverem o melhoramento genético dos animais, o que favorece o desempenho dos mesmos nos esportes que forem destinados, como observado nos resultados obtidos nesta pesquisa.

Considerando o grupo que utiliza a transferência de embriões, observou-se que $100 \%$ das receptoras são dos criadores e que não são utilizados a totalidade de animais possíveis na reprodução (Quadro 6), podendo sugerir que existe um acompanhamento do mercado por parte dos ofertantes para disponibilização de determinado número de animais por ano e a manutenção do valor da genética utilizada na propriedade. 
Quadro 6 - Tamanho do plantel e quantidade de animais utilizados anualmente na reprodução por cada criador do Brasileiro de Hipismo (Número de respondentes: 6)

\begin{tabular}{|c|c|c|}
\hline Criador & Tamanho do Plantel & $\mathbf{N}^{\mathbf{0}}$ de animais usados na reprodução \\
\hline 1 & 12 & 12 \\
\hline 2 & 12 & 12 \\
\hline 3 & 16 & 3 \\
\hline 4 & 24 & 6 \\
\hline 5 & 40 & 10 \\
\hline 6 & 180 & Não informado \\
\hline
\end{tabular}

Fonte: Própria autoria.

Das propriedades que utilizam garanhão próprio, uma possui um garanhão para três éguas utilizadas na reprodução; outra emprega um garanhão para seis éguas, e a terceira não informou a proporção garanhão/éguas cobertas, sugerindo que esses animais são utilizados apenas para coberturas de repasse, quando a utilização de IA e TE apresentam algum problema.

Nem todas as propriedades possuem garanhão no local e metade não possui garanhão, utilizando sêmen congelado ou fresco na reprodução. Esse fato indica, mais uma vez, a preocupação com o melhoramento genético dos animais produzidos, e, além disso, estão ligados à alta taxa de IA e TE praticada pelos criadores. Das propriedades que possuem garanhões (três criadores), foi questionado em quais atividades estes garanhões são empregados. Foram obtidas cinco respostas (algumas propriedades utilizam seus animais em mais de uma atividade). As atividades declaradas foram: reprodução (dentro da porteira), venda de sêmen e competições.

Dos garanhões existentes nos haras, a maioria é destinada a reprodução e para reprodução e competições, pois o cavalo precisa ser reconhecido pelo seu desempenho principalmente quando se trata de um garanhão jovem e em consolidação como "raçador".

Os custos da dose da Inseminação Artificial (IA) e o custo do trabalho associado (Quadro 7), têm marcante ação da metodologia de reprodução utilizada o que leva a certa disparidade nos dados. 
Quadro 7 - Custo da dose da IA e custo do trabalho associado por criador (Número de respostas: 7).

\begin{tabular}{|c|l|l|}
\hline Criador & \multicolumn{1}{|c|}{ Custo da dose } & \multicolumn{1}{c|}{ Custo do trabalho associado } \\
\hline 1 & De $\mathrm{R} \$ 2.130$ a $\mathrm{R} \$ 12.780$ & $\mathrm{Não}$ informado \\
\hline 2 & $\mathrm{R} \$ 2.000$ & $\mathrm{R} \$ 2.000$ \\
\hline 3 & Não informado* & $\mathrm{R} \$ 2.000$ \\
\hline $4 * *$ & $\mathrm{R} \$ 1.500 * * *$ & $\mathrm{R} \$ 2.000 * * *$ \\
\hline 5 & Não informado & $\mathrm{R} \$ 3.000$ \\
\hline $4 * *$ & $\mathrm{R} \$ 5.000 * * * *$ & $\mathrm{R} \$ 3.500 * * * *$ \\
\hline 6 & De $\mathrm{R} \$ 4.260$ a $\mathrm{R} \$ 8.520$ & $\mathrm{R} \$ 6.000$ \\
\hline
\end{tabular}

Fonte: Própria autoria. Legenda: * sêmen próprio, $* * 4^{\circ}$ criador informou valores de sêmen fresco e sêmen congelado, *** sêmen fresco, **** sêmen congelado.

O custo mais alto apresentado da dose é de $\mathrm{R} \$ 12.780$ e o mais baixo, de $\mathrm{R} \$ 1.500$. Com relação ao custo do trabalho associado, o valor mais alto é de $\mathrm{R} \$ 6.000$ e o mais baixo de $\mathrm{R} \$$ 2.000. Os custos mais altos da dose se explicam pelo fato de se tratar de sêmen importado, principalmente da Europa. Tais custos foram passados em Euros e convertidos pelo câmbio de $\mathrm{R} \$ 4,26$ por Euro (do dia 15/12/2015). Vieira (2011) verificou que os custos com IA variaram, naquele ano, entre $\mathrm{R} \$ 185,00$ e R \$ 510,00. Essa divergência no custo do procedimento deve-se ao fato de o custo da dose da maioria dos criadores ter sido cotado em Euros, como informado anteriormente.

Nos casos onde foi empregado o uso de receptoras, observou-se que 83,33\% das propriedades que trabalham com esta possibilidade possuem suas próprias receptoras e que o custo médio é de $\mathrm{R} \$ 2.000$ por animal; uma propriedade aluga cada receptora pelo valor de $\mathrm{R} \$$ 1.500. Este custo informado pelos criadores, abrange um período médio de 15 meses.

O custo da transferência de embriões é apresentado na figura abaixo: 
Figura 25 - Distribuição da frequência de propriedades por custo da transferência de embriões (TE) (Número de respondentes: 5)

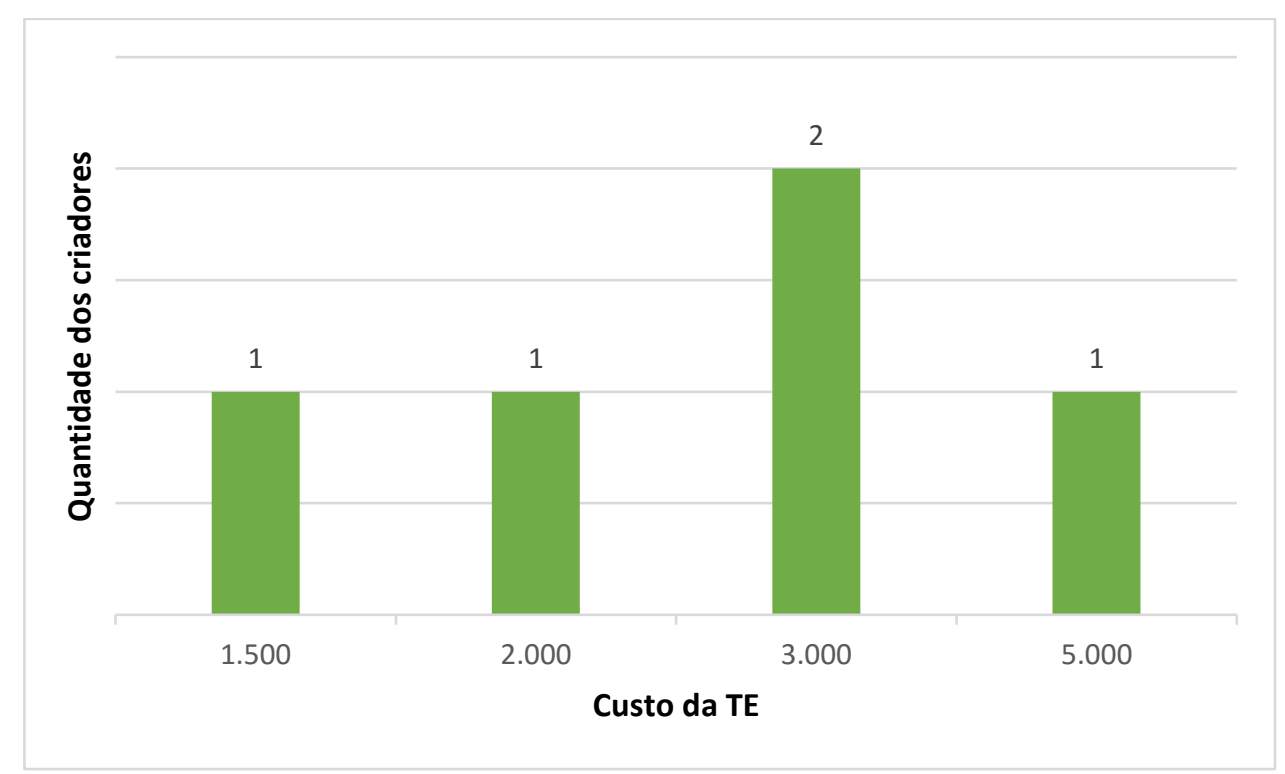

Fonte: Própria autoria.

Como se verifica, duas propriedades têm valor de $\mathrm{R} \$ 3.000$ para realizar a TE. O custo mais elevado observado foi de $\mathrm{R} \$ 5.000$ por TE e o mais baixo foi de $\mathrm{R} \$ 1.500$. Vieira (2011), apontou que o custo da TE na criação do Mangalarga variou entre R $\$ 1.300$ e R \$3.000. O custo mais elevado na criação do Cavalo BH pode ser explicado, provavelmente, pelo efeito da inflação (a pesquisa de Vieira foi em 2011, enquanto esta foi em 2015). Além disso, pela destinação dos animais (competições) é possível que tal serviço seja mais valorizado (por conta da importância do melhoramento genético dos animais).

Em seguida, foi questionada qual a faixa etária de venda dos animais, bem como a média de preço. Tais informações podem ser visualizadas no quadro a seguir:

Quadro 8 - Preços dentro da porteira ou leilões por faixa etária dos potros, em R \$ (Número de respostas: 10).

\begin{tabular}{|c|r|r|r|r|}
\hline \multirow{2}{*}{ Criador } & \multicolumn{4}{|c|}{ Faixa etária } \\
\cline { 2 - 5 } & 6 meses & 12 meses & $\mathbf{2 4}$ a 48 meses & > 48 meses \\
\hline 1 & 28.000 & - & 60.000 & 70.000 \\
\hline 2 & - & - & 30.000 & - \\
\hline 3 & 15.000 & 18.000 & 30.000 & 40.000 \\
\hline 4 & - & - & 50.000 & 80.000 \\
\hline Média & $\mathbf{2 9 . 0 0 0}$ & $\mathbf{1 8 . 0 0 0}$ & $\mathbf{4 2 . 5 0 0}$ & $\mathbf{5 3 . 3 3 3}$ \\
\hline
\end{tabular}

Fonte: Própria autoria. 
A média de preço para cada faixa etária dos animais é de $\mathrm{R} \$ 29.000$ para 6 meses, $\mathrm{R} \$$ 18.000 para 12 meses, $\mathrm{R} \$ 42.500$ para $24-48$ meses e $\mathrm{R} \$ 53.333$ para animais superiores a 48 meses. Para animais de 6 meses o maior valor foi de $\mathrm{R} \$ 28.000$. Para animais com 24-48 meses o maior valor foi de $\mathrm{R} \$ 60.000$ e para animais maiores que 48 meses o maior valor foi de $\mathrm{R} \$$ 80.000. Se forem comparados os preços dos animais vendidos dentro da porteira ou em leilões realizados pelos criadores com os preços dos animais vendidos em leilões realizados pela $\mathrm{ABCCH}$, tem-se que os preços dentro da porteira são superiores, exceto para animais de 12 meses, em que a média de preço é a mesma. Lembrando que os preços informados pela $\mathrm{ABCCH}$ foram: R \$ 18.000 animais de 12 meses; $\mathrm{R} \$ 25.000$ animais de 24 meses; $\mathrm{R} \$ 30.000$ animais de 36 meses e R\$ 40.000 animais de 48 meses $^{21}$. A informação de que o preço dentro da porteira é mais elevado que os preços dos leilões realizados pela associação é reflexo do fato de os leilões realizados pela $\mathrm{ABCCH}$ serem de fomento a criadores ainda não consolidados no mercado. Importante ressaltar que estes valores se tratam de médias de preços. Ocorre, em alguns casos, de animais de competições, como é o caso do Brasileiro de Hipismo, atingirem preços de mercado superiores a estes.

Somando-se os custos médios obtidos com a aplicação dos questionários, chegou-se a um custo médio anual de manutenção de $\mathrm{R} \$ 5.709,72$.

No caso de leilões realizados pela $\mathrm{ABCCH}$ ou pelos próprios criadores da raça, a realidade dos mesmos é bastante parecida com o que constatou o estudo de Muto (1983). Nas transações de compra efetuadas nos leilões, a situação a que se chega pode realmente se aproximar do Ótimo de Pareto, uma vez que as partes chegaram a um acordo quanto ao preço pago pelo animal e a situação não teria como melhorar para um dos dois agentes, sem necessariamente piorar para um deles. Uma situação é Ótimo de Pareto quando não pode melhorar para um dos agentes envolvidos sem necessariamente piorar para o outro agente.

Como afirmaram Oddie et al. (2014) vários são os componentes que determinam o preço de um bem, inclusive de um cavalo. Quando este for o caso, os componentes são tais como a raça, cor, idade, altura, temperamento e capacidade de uso em potencial. Além disso, como os autores apontaram, realmente animais com idades diferentes e capacidade de uso em potencial (qualidade do animal), faz com que os preços sejam diferentes. Isto explica o porquê de os animais terem apresentado preços diferentes de acordo com a idade e com o haras criados (os bens são diferenciados na qualidade, apresentando, assim, preços diferentes de um criador para outro).

${ }^{21}$ Os animais vendidos em leilões são, em geral, iniciados no salto em liberdade para que se possa verificar a habilidade de cada indivíduo. 
Em seguida foi questionado o número de funcionários que a propriedade possui. Tais informações constam na figura abaixo:

Figura 26 - Quantidade de propriedades por quantidade de funcionários empregados (Número de respondentes: 5).

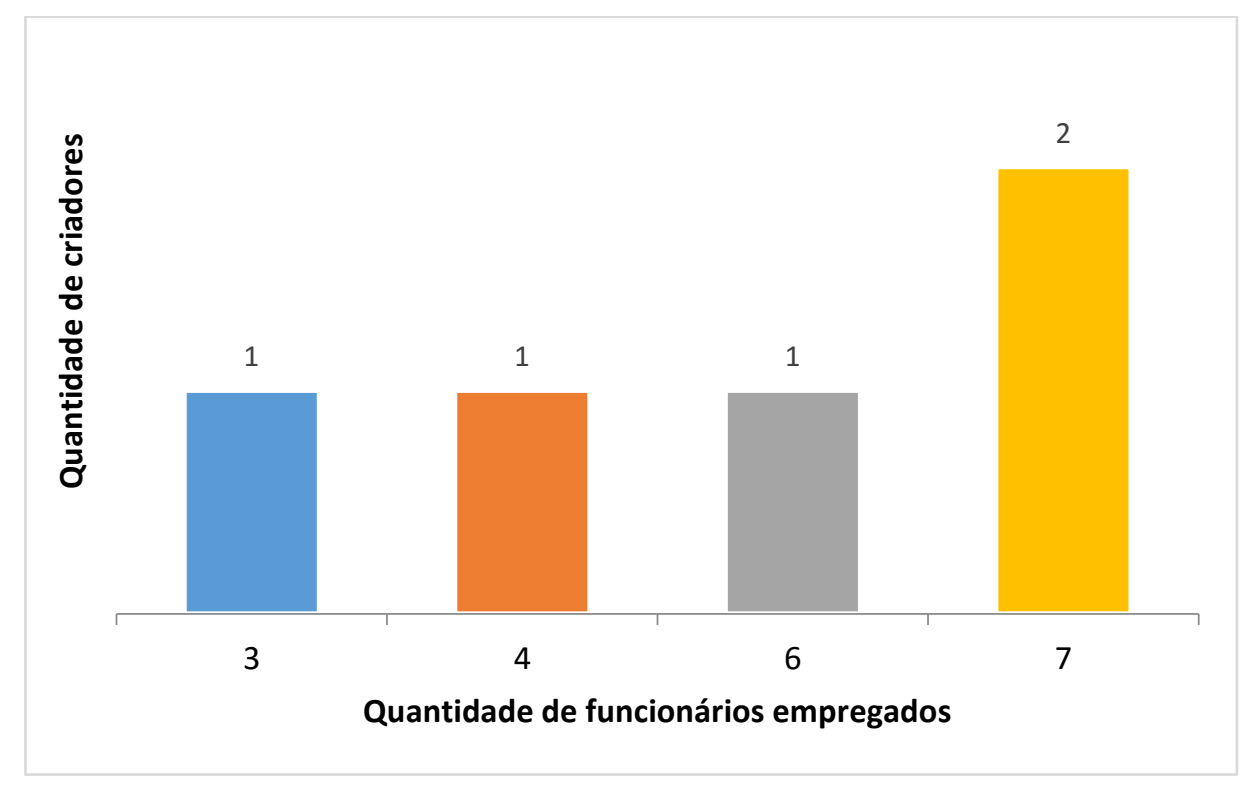

Fonte: Própria autoria.

Duas propriedades possuem sete funcionários empregados. Tais resultados mostram que a criação de cavalos necessita de uma quantidade razoável de mão-de-obra. Vieira (2011), constatou que a média de funcionários empregados na criação dos cavalos Mangalarga era de 3,13. Este número mais elevado de funcionários empregados nas propriedades criadoras do $\mathrm{BH}$ (média de 5,4) pode ser reflexo da destinação dos animais: como são destinados ao esporte (principalmente salto e CCE), a criação dos animais necessita de cuidados especiais (doma, manutenção dos animais em competições, etc.).

A seguir foi questionado qual o cargo dos funcionários, bem como o custo de tais cargos. Os dados referentes aos cargos são apresentados na figura abaixo: 
Figura 27 - Percentual de funcionários por cargo na totalidade de funcionários das propriedades (Número de respondentes: 6).

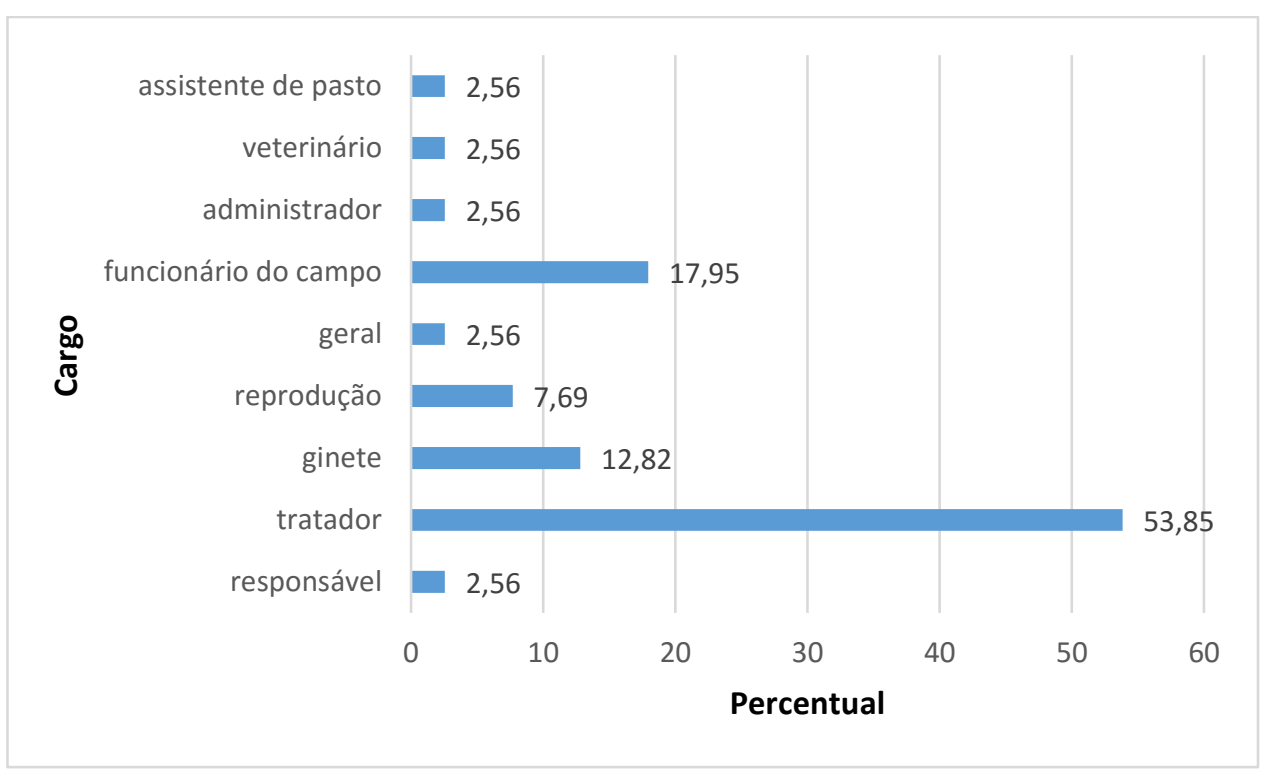

Fonte: Própria autoria.

Como verifica-se na figura acima, o cargo mais comum entre as propriedades é o de tratador totalizando 53,85\% do total de funcionários por cargo. A seguir tem-se o cargo de funcionário do campo, com 17,95\%, e ginetes, com 12,82\%. Os funcionários registrados como "do campo" são todos contratados de um único criador, que possui 7 trabalhadores empregados na criação do cavalo BH. Os custos destes cargos são apresentados no quadro abaixo:

Quadro 9 - Custo por cargo e média do custo por cargo, em R\$ (Número de respostas: 11).

\begin{tabular}{|l|r|r|r|r|r|r|}
\hline \multirow{2}{*}{\multicolumn{1}{c|}{ Cargo }} & \multicolumn{5}{c|}{ Criador } & Média \\
\cline { 2 - 7 } & 1 & \multicolumn{1}{|c|}{2} & \multicolumn{1}{c|}{4} & 5 & \\
\hline Administrador & - & - & - & 2.500 & - & -2.500 \\
\hline Assistente de pasto & - & - & - & - & Não informado & - \\
\hline Funcionário do campo & - & - & 2.000 & - & Não informado & 2.000 \\
\hline Geral & - & 2.000 & - & 1.000 & - & 1.500 \\
\hline Ginete & - & 5.000 & - & 2.000 & - & 3.500 \\
\hline Reprodução & - & 2.000 & - & - & - & 2.000 \\
\hline Responsável & - & 3.000 & - & - & - & 3.000 \\
\hline Tratador & 2.000 & 2.000 & - & - & Não informado & 2.000 \\
\hline Veterinário & - & - & - & 5.000 & & 5.000 \\
\hline
\end{tabular}

Fonte: Própria autoria.

Como se pode verificar no quadro acima, a média do custo mensal com tratadores é de $\mathrm{R} \$ 2.000$ e com ginetes é de $\mathrm{R} \$ 3.500$. O custo mensal mais elevado declarado foi o de $\mathrm{R} \$$ 
5.000 (ginete e veterinário). Tal fato pode ser explicado pela importância de que o haras mantenha seus animais em competições, para que seus cavalos possam ter maior visibilidade e credibilidade no mercado. O custo mensal mais baixo declarado foi com o cargo de funcionário geral.

Em seguida foi questionado se o haras recebe assistência de veterinário, agrônomo ou zootecnista. Como resultado, têm-se que 100\% dos criadores recebem algum tipo de assistência (veterinário e agrônomo). Nenhum dos criadores entrevistados declarou receber assistência de um profissional de zootecnia. Pode-se verificar qual a assistência e qual o custo da mesma no quadro abaixo:

Quadro 10 - Especificação da assistência recebida, custo e média de custo de tal assistência, em $\mathrm{R} \$$ (Número de respostas: 8).

\begin{tabular}{|c|r|r|r|r|}
\hline \multirow{2}{*}{ Criador } & \multicolumn{2}{|c|}{ Assistência veterinária } & \multicolumn{2}{c|}{ Assistência agronômica } \\
\cline { 2 - 5 } & Presença & Custo médio mensal & Presença & Custo médio mensal \\
\hline 1 & Sim & Não informado & Sim & Não informado \\
\hline 2 & Sim & Não informado & Sim & Não informado \\
\hline 3 & Sim & 200 & Não & - \\
\hline 4 & Sim & 1.000 & Não & - \\
\hline 5 & Sim & 2.500 & Não & - \\
\hline 6 & Sim & 5.000 & Não & - \\
\hline Média & - & $\mathbf{2 . 1 7 5}$ & - & \\
\hline
\end{tabular}

Fonte: Própria autoria.

Como se pode verificar, todos os criadores entrevistados recebem assistência de veterinários e dois deles ainda recebem assistência de agrônomos. O custo médio com veterinários é de $R \$ 2.175$, sendo o maior valor de $R \$ 5.000$ e o menor de $R \$ 200$. Os custos com agrônomos não foram informados.

Em seguida trata-se da base da alimentação dos animais, conforme apresentado na figura abaixo: 
Figura 28 - Base da alimentação dos animais (Número de respostas: 12).

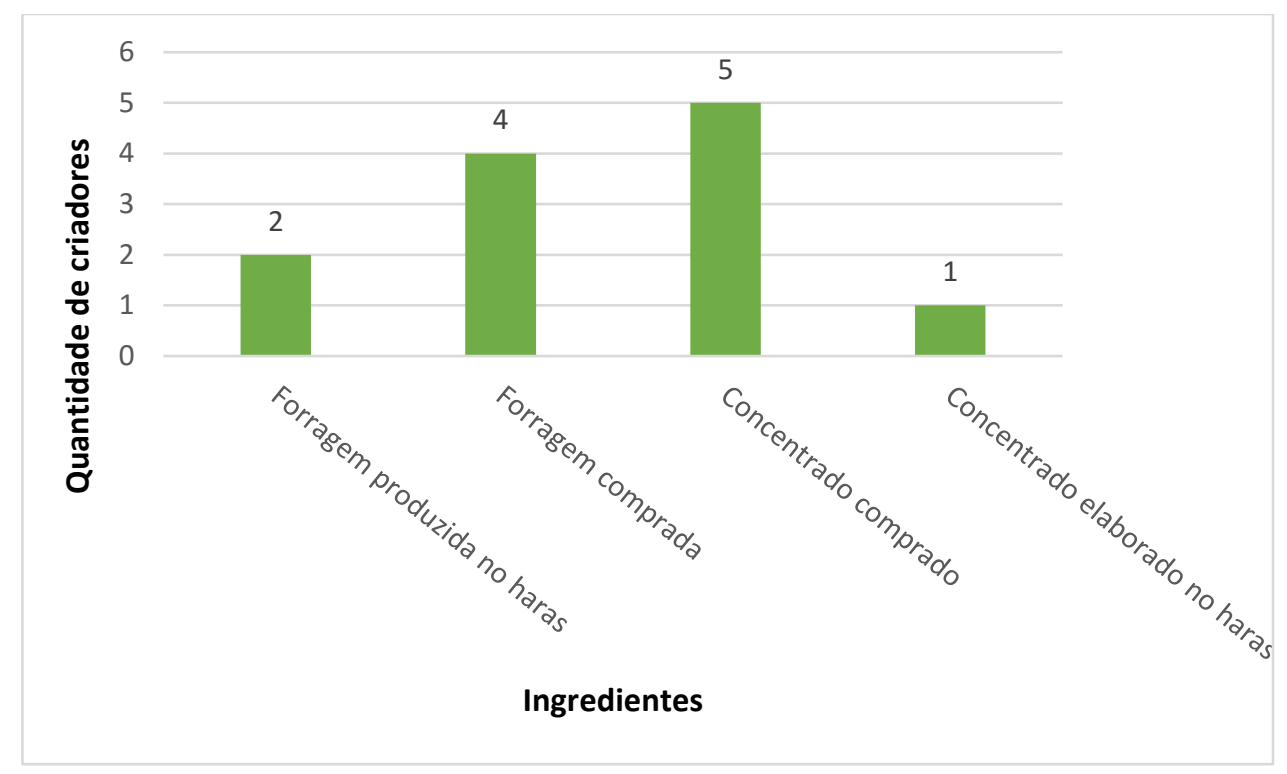

Fonte: própria autoria.

É possível se verificar que quatro criadores compram a forragem, sendo a mesma o tifton ou o coast-cross. Com relação ao concentrado, cinco dos criadores compram ração comercial, sendo as marcas utilizadas a Pavo®, a Socil® e a Guabi®, e somente um deles elaboram a ração na propriedade. Tal propriedade utiliza como ingredientes o milho "rolão", farelo de soja, farelo de trigo, feno moído, coequiplus ${ }^{\circledR}$ e calcita. Os criadores grandes podem elaborar o concentrado no haras, tornando o custo da alimentação mais barato. Porém, a qualidade do concentrado elaborado no haras muitas vezes é menor, se comparado ao comercial. Além disso, pode acarretar problemas de saúde para o animal. Por conta disso, os criadores têm preferido oferecer os concentrados comerciais aos animais.

Importante ressaltar que este criador que elabora sua própria ração é de grande porte, com 180 animais no plantel. Os dados indicam que, para propriedades de pequeno ou médio porte, a elaboração de concentrado na propriedade pode não apresentar a melhor relação custobenefício. Para propriedades com quantidade grande de animais, parece compensar elaborar o concentrado no local. Além disso, o proprietário do haras que elabora o concentrado fornecido aos animais do plantel possui fazendas em que são produzidos milho, soja e aveia - o milho e a soja são utilizados na produção do concentrado, o que sugere uma verticalização parcial da produção (termo utilizado em economia para descrever casos em que as empresas produzem uma parte ou a totalidade dos bens utilizados na cadeia produtiva de determinado produto). Porém, a elaboração do concentrado na propriedade pode não ser considerada tão eficaz no que diz respeito à qualidade do produto fornecido para o animal. Pode ocorrer de o concentrado 
produzido no haras acabar trazendo complicações por conta da qualidade, como é o caso das cólicas. Além disso, as rações comerciais oferecem a possibilidade de fornecer ao animal o concentrado necessário para a realidade e necessidade dos equinos: potros em fase de crescimento, éguas lactantes ou em gestação, animais de competição, etc.

Vieira (2011) verificou que 56,08\% das propriedades criadoras do cavalo Mangalarga forneciam apenas pastagem para os seus animais, contra 19,19\% de feno comprado. Além disso, $50,52 \%$ dessas propriedades não fornecem concentrado para seus animais. Essa diferença é reflexo da preocupação dos criadores do Cavalo BH em produzir um animal de ponta, um atleta de alta performance, devido - mais uma vez - à principal destinação do BH: competição de salto e CCE.

Com relação ao custo da alimentação, tais dados são apresentados no quadro abaixo.

Quadro 11 - Custo com alimentação por propriedade, R\$ (Número de respondentes: 5).

\begin{tabular}{|c|c|c|c|}
\hline Criador & Concentrado & Feno & R\$/mês \\
\hline 1 & $2,00 / \mathrm{kg}$ & $1,00 / \mathrm{kg}$ & - \\
\hline 2 & $2,00 / \mathrm{kg}$ & $0,70 / \mathrm{kg}$ & - \\
\hline 3 & $0,90 / \mathrm{kg}$ & $0,30 / \mathrm{kg}$ & - \\
\hline 4 & & - & 500 \\
\hline 5 & & - & 1.440 \\
\hline Média & $\mathbf{1 , 6 3}$ & $\mathbf{0 , 6 7}$ & $\mathbf{9 7 0 , 0 0}$ \\
\hline
\end{tabular}

Fonte: Própria autoria.

A média do custo com concentrado por quilo é de $\mathrm{R} \$ 1,63$, tendo o menor valor de $\mathrm{R} \$$ 0,90 (concentrado elaborado no haras). A média do custo do feno é de $\mathrm{R} \$ 0,67 / \mathrm{kg}$, tendo o menor valor de $\mathrm{R} \$ 0,30 / \mathrm{kg}$ (feno produzido na propriedade). Os menores custos apresentados, tanto no que se refere ao concentrado quanto ao que se refere ao volumoso, pertencem ao maior criador entrevistado. Dois criadores informaram o custo em $\mathrm{R} \$ /$ mês/animal. A média foi de $\mathrm{R} \$$ 970,00/mês/animal, sendo o menor custo de R \$ 500,00/mês/animal.

Vieira (2011) verificou que a média de preço mensal do concentrado elaborado na propriedade era de $\mathrm{R} \$ 0,90 / \mathrm{kg}$ (exatamente o mesmo valor declarado pelo haras criador de $\mathrm{BH}$ que produz seu concentrado). Já o concentrado comercial era de $\mathrm{R} \$ 1,23 / \mathrm{kg}$ e hoje é de $\mathrm{R} \$ 1,63$. Tal diferença pode ser explicada pela inflação e também pela qualidade do concentrado fornecido aos animais BH's (que, muito provavelmente é superior).

Para as propriedades que possuem o serviço de alojamento de animais (aluguel de baias), o valor cobrado pelo serviço variou entre $\mathrm{R} \$ 300$ e $\mathrm{R} \$ 1.700$. Das seis propriedades entrevistadas, três delas oferecem o serviço de alojamento. Estes serviços são mais utilizados 
no caso de férias do animal (entre temporadas de competição ou por motivo de saúde) e aposentadoria. No caso de um dos criadores, os animais retornam após serem vendidos em leilão realizado pelo haras em questão para serem domados pelo profissional do criador, que trabalha com a doma racional. O custo mais baixo declarado não inclui alimentação dos animais. No valor de R 1.700 está inclusa a alimentação do animal e vermífugos. Com relação ao custo mensal com fármacos, os mesmos estão inclusos em duas das propriedades que trabalham com o serviço de alojamento de animais. A terceira propriedade que oferece este serviço não informou os custos. Além destas, uma quarta propriedade tem o custo médio de R\$ 20/cavalo/mês e outra declarou ter o custo médio por cavalo de R \$ 32/cavalo/mês. Os fármacos utilizados nos animais variam de acordo com a necessidade: caso ocorra alguma emergência ou no caso de o animal apresentar alguma necessidade especial, como ocorre no caso de alguma doença diagnosticada, que necessita de tratamento contínuo, por exemplo.

Foi questionado se a propriedade possui ginete. Verificou-se que quatro dos seis criadores entrevistados possuem ginetes contratados. Tais informações estão ligadas à questão feita um pouco mais adiante que pergunta se há a manutenção dos animais da propriedade em competições: para propriedade que mantém seus animais em competições, torna-se necessário que a mesma possua ginetes. No caso de propriedades que não possuem ginetes, deve-se fazer uma observação: uma delas possui um adestrador e trabalha com a venda de potros com idade de 24 meses. Durante a entrevista, obteve-se a informação de que a maioria dos animais deste criador é vendida em leilão anual realizado pelo haras, e que, na maior parte dos casos, os novos proprietários encaminham os animais novamente para este criador, para que o adestrador em questão os dome com a doma racional. É neste momento que o haras cobra por alojamento de animais.

Pode-se verificar a quantidade de ginetes por propriedade e seu custo nas figuras abaixo: 
Figura 29 - Quantidade de propriedades por número de ginetes contratados (Número de respondentes: 4).

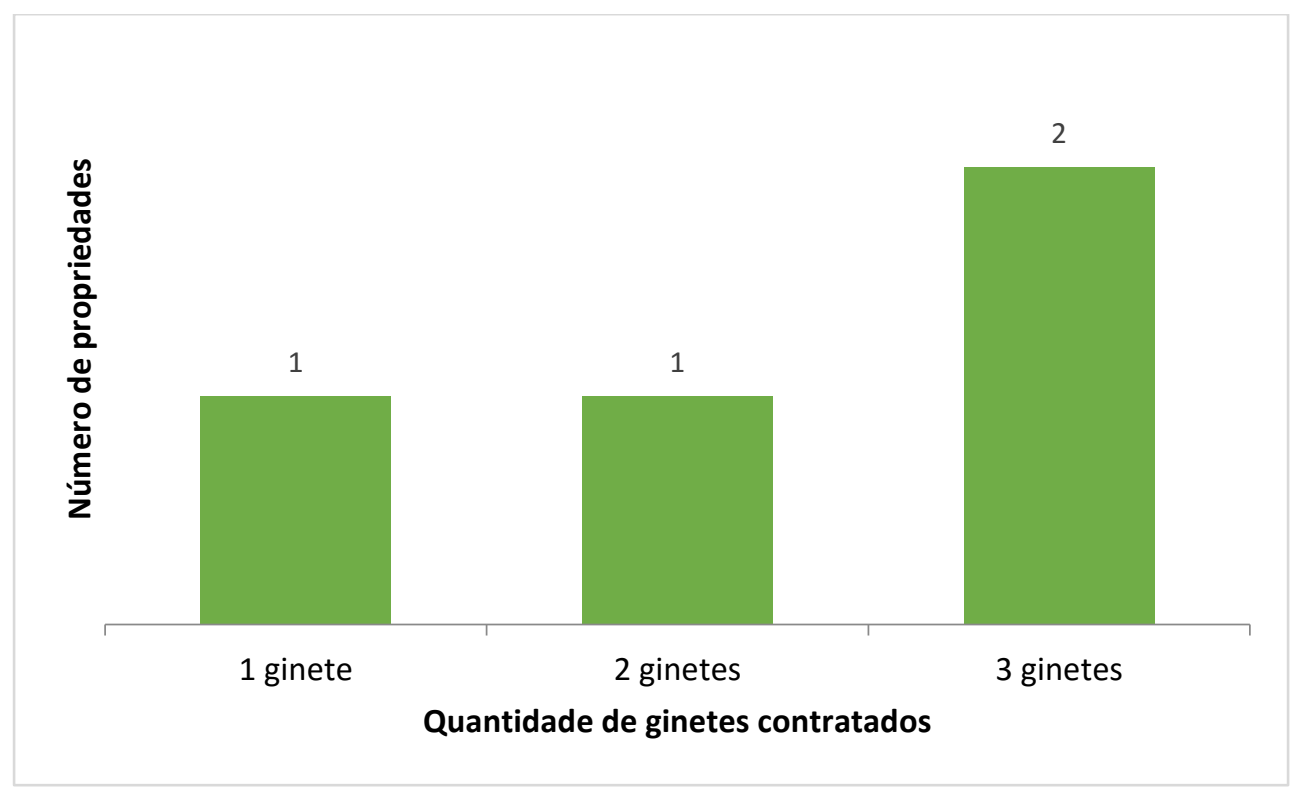

Fonte: Própria autoria.

Figura 30 - Custo mensal de cada propriedade com cada ginete contratado (Número de respondentes: 3 )

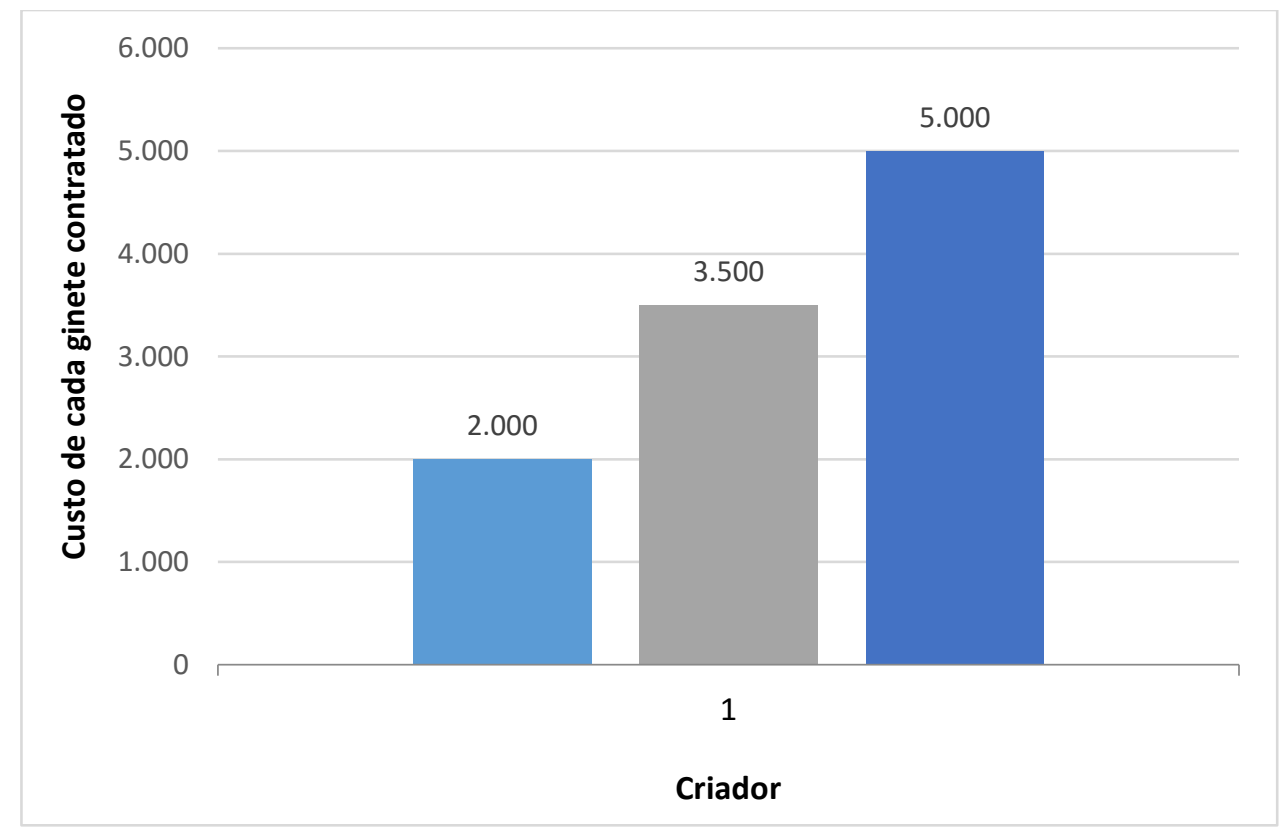

Fonte: Própria autoria.

Como pode-se verificar o custo mensal por variou entre $\mathrm{R} \$ 2.000,00$ e $\mathrm{R} \$ 5.000,00$, sendo que cada valor de custo mensal com ginete apareceu uma vez. Uma das quatro propriedades que possui ginetes contratados não informou o custo mensal de cada profissional. 
A quantidade de ginetes por propriedade está diretamente ligada ao tamanho do plantel dos criadores. Criadores de pequeno porte possuem apenas um ginete. No caso do criador de maior tamanho, que possuía 180 animais no plantel, faziam parte do quadro de funcionários da propriedade três ginetes.

Com relação à modalidade alvo dos animais criados nas propriedades, os dados podem ser verificados na figura abaixo:

Figura 31 - Percentual das respostas por modalidade alvo das propriedades criadoras (Número de respostas: 10$)$

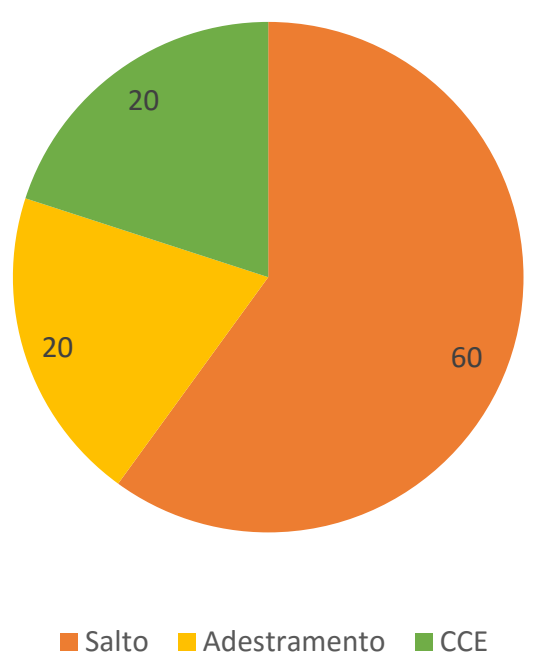

Fonte: Própria autoria.

Verifica-se que $60 \%$ das respostas obtidas informam que a propriedade destina seus animais ao salto. Este fato corrobora a ideia de que o salto, dentre as três modalidades que podem ser praticadas com o cavalo $\mathrm{BH}$, é a mais desenvolvida no país, o que justifica maior percentual das respostas. Observou-se que algumas propriedades assinalaram mais de uma modalidade alvo, como foi o caso do criador com maior tamanho de plantel. Os animais podem ser destinados para o salto, adestramento ou CCE. Tal destinação varia, de acordo com o criador, por conta do produto final alcançado: morfologia, temperamento e saúde de cada equino.

Em seguida, questionou-se se os animais participam de competições. Os resultados podem ser verificados na figura abaixo: 
Figura 32 - Os animais participam de competições? (Número de respondentes: 5).

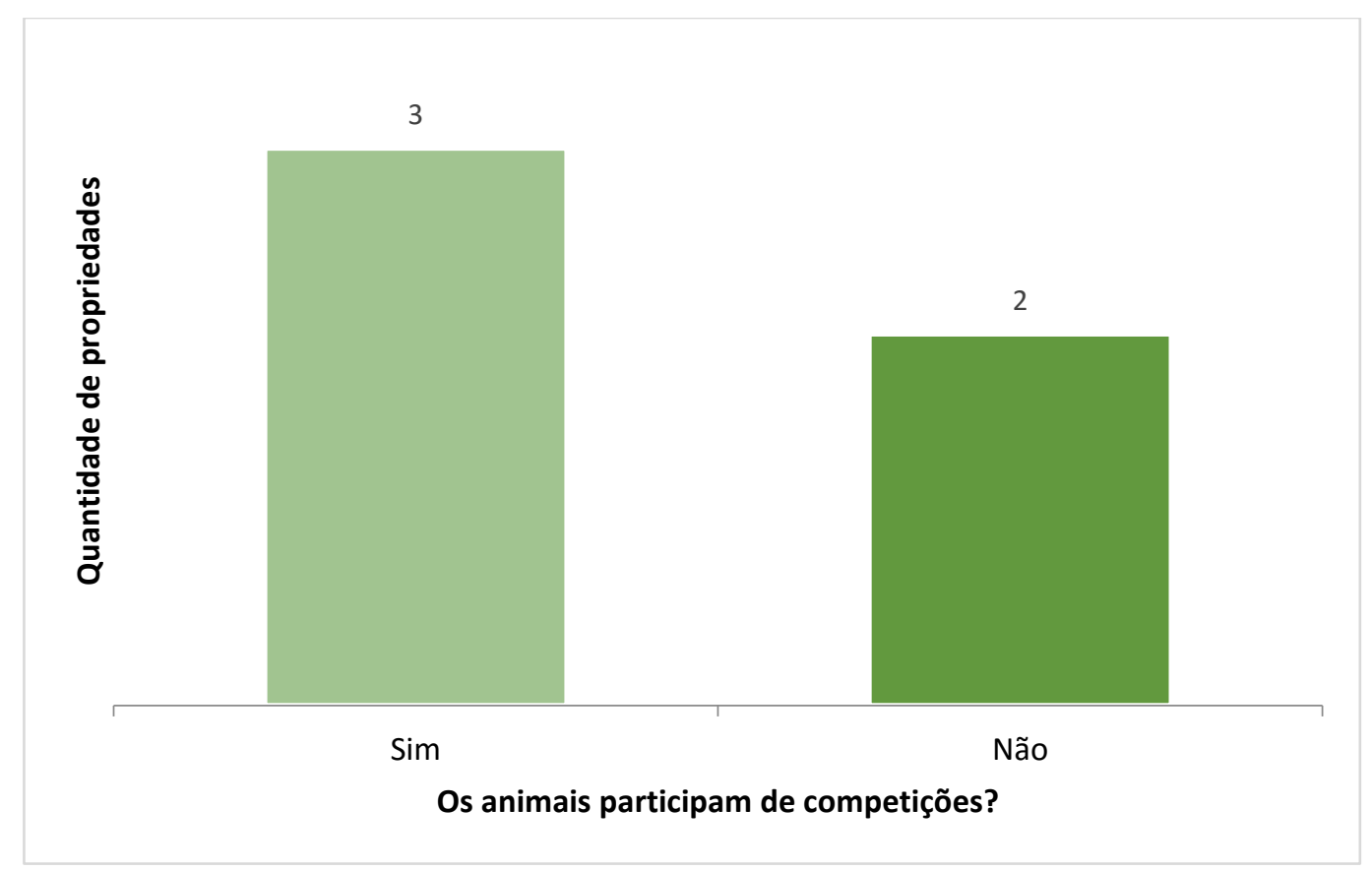

Fonte: Própria autoria.

Têm-se que 3 propriedades mantêm seus animais ativos em competições. Tais números são bem parecidos com os percentuais referentes à questão feita anteriormente, que indagava se a propriedade possuía ou não ginete (4 delas possuem). Como dito anteriormente, quando a propriedade mantém seus animais em competição, para promoção de seus produtos, torna-se necessário que a mesma possua ginetes contratados, para que estes exercitem os animais, os condicionem e os mantenham em treinamento. Além desse trabalho realizado dentro da porteira, os ginetes são responsáveis por conduzirem os animais nos campeonatos e competições. Uma das propriedades entrevistadas declarou que mantinha seus garanhões em competições, porém os mesmos eram trabalhados e participavam de competições sob a montaria do filho do proprietário, e, por conta disso, o haras não possuía ginetes profissionais no seu quadro de funcionários.

A seguir questionou-se se todos os animais são registrados na $\mathrm{ABCCH}$, e todos os criadores entrevistados responderam que $100 \%$ dos animais nascidos nos seus haras eram registrados na associação da raça.

Por fim, foram feitas três perguntas com relação ao comportamento e características da propriedade e proprietários: se a variação nos custos de produção altera a quantidade produzida de animais; se a propriedade utilizaria uma tecnologia disponível para diferenciar seus animais; e se o proprietário possui outra fonte de renda 
Cinco dos seis criadores possui outra fonte de renda. Tal fato pode ser comparado ao resultado do estudo de Aldridge, Koenen e Phillipson (2004), segundo o qual a criação de cavalos de esporte na Europa pode ter sua eficiência econômica questionada. Importante ressaltar que a única propriedade em que foi declarada não existir outra fonte de renda obtém sua renda da criação de cavalos e da escola de equitação que funciona na propriedade, que é de grande porte e atende cerca de 250 alunos, sendo assim, a renda não provém exclusivamente da criação de cavalos. Os dados obtidos sobre os custos de criação do cavalo BH sugerem que não se trata de uma atividade rentável, mas os criadores parecem não dar importância a este fato. $\mathrm{Na}$ maioria das entrevistas ficou claro que os criadores atuam neste ramo por conta de gostarem dos cavalos. Desta maneira, a criação de cavalos traz retornos não pecuniários. Outra informação relevante aponta que os criadores, muitas vezes, são também consumidores de cavalos.

Dos entrevistados, $60 \%$ deles afirmou que utilizaria alguma técnica disponível no mercado para agregar valor ao produto final. Além disso, 83,33\% dos entrevistados respondeu que a variação nos custos de produção não altera a quantidade produzida. Tais dados podem ser um reflexo da ineficiência econômica deste mercado, sinalizada no estudo de Aldridge, Koenen e Phillipson (2004), uma vez que, teoricamente, os custos de produção são levados em consideração no momento de decidir a quantidade a ser produzida, uma vez que a empresa possui certa quantidade de capital disponível para o emprego na produção. Além disso, estes dados apontam que a oferta do Cavalo Brasileiro de Hipismo é inelástica ao custo de produção. Tal fato pode ser explicado por conta de os custos de produção representarem uma parcela pequena do valor criado ao consumidor. Além do mais, o consumo do cavalo BH traz benefício não pecuniário e de grande magnitude, o que torna a oferta inelástica. 


\section{CONCLUSÃO}

Por se tratar de um estudo exploratório, a pesquisa possui certa limitação como amostragem reduzida. Ademais, há poucos estudos anteriores sobre o tema que possam servir de base. Desta maneira, a discussão dos resultados deve ser considerada com as devidas ressalvas. Ainda assim, entende-se que o objetivo de levantar informações iniciais sobre um setor ainda não estudado foi atendido.

A análise dos resultados obtidos permite sugerir que o mercado do Cavalo Brasileiro de Hipismo possui estrutura que se aproxima da concorrência monopolística. Apesar de haver muitos ofertantes e demandantes do animal, cada produtor emprega tecnologia e mão-de-obra especializada, buscando sempre o melhoramento dos animais produzidos, visando sua diferenciação e agregação de valor. Outro fator importante deste mercado é o fato de que, apesar de serem empregadas técnicas relativamente semelhantes pelos produtores, cada animal produzido é único, por conta de sua morfologia, saúde, desempenho no esporte e temperamento, tornando-os, assim, diferenciados em relação aos demais. Essa diferenciação com relação aos outros animais, no que se refere à qualidade e outros padrões, faz com que cada produtor tenha certo poder de monopólio no mercado, podendo ter certa gerência no preço cobrado por seus animais.

Com relação à eficiência econômica da criação, verificou-se que a maior parte dos criadores possuem outra fonte de renda. Em alguns casos, os proprietários comentaram que se tratava mais de um hobby e uma "paixão" do que de uma fonte de renda propriamente dita. Outro fato que colocou a eficiência econômica da equideocultura do cavalo de esporte em questão foi a alta frequência dos entrevistados ter declarado que os custos de produção não alteram a quantidade de animais produzidos. Além disso, somente um dos criadores entrevistados declarou preços de venda que possibilitavam que o investimento nos equinos da raça estudada tivesse taxa de retorno positiva.

Com relação aos demandantes e usuários dos animais, os mesmos são realmente - ao que os resultados indicaram - de classe social mais elevada. Muitos dos entrevistados declararam que o preço do animal não foi o fator determinante no momento da compra, e que, caso houvesse expectativa de queda do preço do cavalo no futuro, não aguardariam para poder comprar a um preço mais baixo, e efetuariam a compra no presente. Tais informações sugerem que o cavalo pode ser considerado um bem superior, e, eventualmente, de luxo.

Uma instituição importante deste mercado é a Associação Brasileira dos Criadores do Cavalo de Hipismo $(\mathrm{ABCCH})$, que regulamenta a produção dos animais desta raça no país, 
evitando com que haja oportunismo por parte dos criadores, no sentido de fiscalizar a linhagem e morfologia dos animais aprovados no stud book. Além disso, a ABCCH age como intermediária das transações de compra e venda dos animais da raça Brasileiro de Hipismo, uma vez que, quando ocorre a mudança de propriedade do animal, os registros destes animais são atualizados na associação, de modo a constar o novo proprietário. Essa atuação da $\mathrm{ABCCH}$ pode ser considerada positiva, uma vez que garante a qualidade dos animais produzidos, possibilitando que a raça seja competitiva no mercado nacional e internacional.

O mercado de Cavalos Brasileiro de Hipismo mostrou-se promissor. Apesar de ter ocorrido uma diminuição na quantidade de animais produzidos anualmente, a quantidade de animais produzidas nos últimos anos manteve em um patamar considerável. Além do mais, a qualidade alcançada dos animais da raça disponibilizados no mercado, por conta da utilização das biotecnologias de inseminação artificial e transferência de embriões, faz com que a raça possa competir com outras raças renomadas utilizadas para o chamado hipismo clássico (adestramento, salto e CCE), inclusive no âmbito internacional. Foram registrados, nos últimos anos, destaques em resultados em competições e em seletivas para o time brasileiro de hipismo, principalmente no salto e no CCE.

O mercado de cavalo de esporte é um nicho de mercado. A criação do cavalo BH não se mostrou rentável e é caracterizada como uma atividade de alto risco, por conta da incerteza do retorno do investimento. Sugere-se que a atividade de produção de equídeos não seja a fonte de renda principal do investidor. 


\section{REFERÊNCIAS}

A REPORT. British Horse Industry Confederation. Londres, mar. 2004. Defra. Disponível em:

<https://www.gov.uk/government/uploads/system/uploads/attachment_data/file/69259/pb925 5-bhic-report-040318.pdf>. Acesso em: 04 set. 2015.

AKERLOF, G. A. The market for lemons. The Quarterly Journal of Economics, Oxford, v. 84, p. $8488-8500$.

ALDRIDGE, L. I; KOENEN, E. P. C. Testing and genetic evaluation of sport horses in an international perspective. In: CONGRESSO MUNDIAL DE CRIAÇÃO PECUÁRIA, 7. 2002, Montpellier. Proceedings... Montpellier, 2002. Disponível em:

$<$ http://www.biw.kuleuven.be/Genlog/livgen/research/interstallion/publications/wcgalppaper.pdf>. Acesso em: 04 Set. 2015.

ALDRIDGE, L. I.; KOENEN, E. P. C.; PHILIPSSON J. An overview of breeding objectives for warmblood sport horses. livestock production science, Philadelphia, v. 88, p. 77-84, 2004.

ALLEN, W. R. The Development and Application of the Modern Reproductive Technologies to Horse Breeding. Reproduction in Domestic Animals. Berlim, v. 40, p. 310-329, 2005.

ANDERSON, H; JOHASSON, D. The Horse Sector: does it matter for the agriculture? AMERICAN AGRICULTURAL ECONOMICS ASSOCIATION ANNUAL MEETING, Denver, 2004. Proceedings... Denver, 2004. Disponível em:

<https://ideas.repec.org/p/ags/aaea04/19999.html>. Acesso em: 04 set. 2015.

ASSAF NETO, A. Mercado financeiro. 9. ed. São Paulo: Atlas, 2009.

ASSOCIAÇÃO BRASILEIRA DOS CRIADORES DE CAVALO DE HIPISMO. Ano 2014: Regulamento s.b.b.c.h. São Paulo. 2014. Disponível em:

<http://brasileirodehipismo.com.br/site/upload/arquivos/regulamento.pdf>. Acesso em: 21 jun. 2014.

ASSOCIAÇÃO BRASILEIRA DOS CRIADORES DE CAVALO DE HIPISMO. Ano 2015: Histórico BH. São Paulo. 2015. Disponível em:

<http://brasileirodehipismo.com.br/site/nhtml/nstbh_historicobh.asp>. Acesso em: 15 maio 2015.

ASSOCIAÇÃO BRASILEIRA DE EMPRESAS DE PESQUISA. ABEP Apresenta Critério Brasil 2015. Disponível em:< http://www.abep.org/>. Acesso em: 31 dez. 2015.

AULER, F. WERLANG, S. R. C. Determinação de preços de ativos, arbitragem, mercado a termo e mercado futuro. EPGE: Ensaios Econômicos. Rio de Janeiro, 1993. Disponível em: <http://bibliotecadigital.fgv.br/dspace/bitstream/handle/10438/632/Determina\%C3\%A7\%C3 $\%$ A3o\%20de\%20Pre\%C3\%A7os\%20de\%20Ativos,\%20Arbitragem,\%20Mercado\%20a\%20T ermo\%20e\%20Mercado\%20Futuro.pdf?sequence=1>. Acesso em: 23 jan. 2016. 
BRASIL. Lei ${ }^{\circ}$ 7.291, de 19 de dezembro de 1984. Dispõe sobre as atividades de equideocultura no país, e dá outras providências. Diário Oficial [da] República Federativa do Brasil. Brasília, DF, 20 dez. 1984. Disponível em:< http://www.planalto.gov.br/ccivil_03/leis/17291.htm>. Acesso em: 13 maio 2015.

CAIADO, J. R. C.; FONSECA, F. A., SILVA, J. F. S., FONTES, R. S. Tratamento de éguas receptoras de embriões visando sua utilização no segundo dia pós-ovulação. Revista Brasileira de Zootecnia. Viçosa, v. 36, p. 360-368, 2007.

CONFEDERAÇÃO BRASILEIRA DE HIPISMO. Histórico - Adestramento. Rio de Janeiro, 2015.Disponível em:<http://www.cbh.org.br/historico-adestramento.html >. Acesso em: 24 out. 2014.

CONFEDERAÇÃO BRASILEIRA DE HIPISMO. Histórico - CCE. Rio de Janeiro, 2014. Disponível em: <http://www.cbh.org.br/historico-cce.html>. Acesso em: 24 out. 2014.

CONFEDERAÇÃO BRASILEIRA DE HIPISMO. Histórico - Salto. Rio de Janeiro, 2014. Disponível em:<http://www.cbh.org.br/historico-salto.html>. Acesso em: 21 out. 2014.

CONFEDERAÇÃO BRASILEIRA DE HIPISMO. O Hipismo no Brasil e a CBH.2010. Rio de Janeiro, 2014. Disponível em: <http://www.cbh.org.br/cbh/historico.html>. Acesso em: 03 set. 2014.

EGBERT, H.The culture of a market: a case csudy of open-air horse markets. Journal of Institutional and Theoretical Economics, Mohr Siebeck, v. 163, p. 493-502, 2007.

FAOSTAT. Food and Agriculture Organization of the United Nations. Production and Livestock. Disponível em: <http://faostat3.fao.org/browse/Q/QA/E〉. Acesso em: 10. ago.2015

FARINA, E. M. M. Q. Competitividade e coordenação de sistemas agroindustriais: um Ensaio atual. Gestão e Produção, São Carlos, v. 6, n. 3, p. 147-161, dez. 1999. Disponível em: 〈http://www.scielo.br/pdf/gp/v6n3/a02v6n3.pdf>. Acesso em: 15. abr. 2014.

FOOTE, R. H. The history of artificial insemination: selected notes and notables. Journal of Animal Science. Champaign, v. 80, p. 01-10, 2002.

FREITAS, A. VIEIRA, S. O que é hipismo. Rio de Janeiro: Casa da palavra, 2007.

GORDON, J. The horse industry contribution to the Australian economy. The Rural Industries Research and Development Corporation, Barton,v. 83, n. 1, 2001.

GRIMES, P. W; RAY, M. A. The determinants of breeding regulation in the horse industry: an empirical analysis. The Journal of Socio-Economics, Texas, v. 20 n. 2, p. 169-180. 1991.

HENESSY, K.; QUINN, K. The future of irish sport horse industry: analysis and recommendation. Irishsporthorse. Dublin. 2006. Disponível em:

<http://www.irishsporthorse.com/_fileupload/publications/strategic_with\%20cover.pdf >. Acesso em: jun. 2014. Acesso em: 11 ago. 2015. 
KRUGMAN, P.; WELLS, R. Introdução a economia. Rio de Janeiro: Elsevier, 2007.

LAKATOS, E. M.; MARCONI, M. A. Fundamentos de metodologia científica. 6. ed. São Paulo: Atlas, 2006.

LIMA, R. A. S.; SHIROTA, R.; BARROS, G. S. C. Estudo do complexo agronegócio cavalo. Piracicaba, 2006. Disponível em:

<http://www.cepea.esalq.usp.br/pdf/cavalo_completo.pdf> Acesso em: 02 ago. 2013.

MANKIW, N. G. Introdução à Ecnomia. 5º ed. São Paulo: Cengage Learning, 2010.

MCGREEVY, P. D. et al. Do vendors value safety in thoroughbred horses in the australian recreational riding horse market?. Journal of Veterinarian Behaviour, Philadelphia, v. 10, p. 153-157, 2015.

MUTO, S. Sequential auctions on bohm-bewerk's horse market. Mathematical Social Science, Holanda, v. 4, p. 117-130, 1983.

NEVES, S; VICECONTI, P. E. V. Introdução a economia. 8. ed. São Paulo: Frase editor, 2007.

NORDHAUS, W. D.; SAMUELSON, P.A. Economia. 3. ed. Rio de Janeiro: Mcgraw-Hill, 2004.

ODDIE, C. F et al. Do vendors value safety in the australian recreational (non-thoroughbred) riding horse market? Journal Of Veterinary Behavior, Newcastle, v. 9, p. 375-381, 2014.

PINDYCK, R. S; RUBINFELD, D. L. Microeconomia São Paulo: Pearson Prentice Hall, 2007.

PLAN for. Rural industries research and development corporation. Borton, 2002. Disponível em:

<http://r.search.yahoo.com/_ylt=AwrBTzGAxelVo6QANkTz6Qt.;_ylu=X3oDMTByOHZyb 21tBGNvbG8DYmYxBHBvcwMxBHZ0aWQDBHNlYwNzcg--

$/ \mathrm{RV}=2 / \mathrm{RE}=1441412608 / \mathrm{RO}=10 / \mathrm{RU}=\mathrm{https} \% 3 \mathrm{a} \% 2 \mathrm{f} \% 2$ frirdc.infoservices.com.au $\% 2$ fdownloa ds\%2f02-026.pdf/RK=0/RS=_7dW2s6Z4jN4rumbz3VMaDDypuA->. Acesso em: 04 Set.

2015.

ROSSETTI, J. P. Introdução à economia. 20. ed. São Paulo: Atlas, 2003.

SCOTT, T. J. et al. Embryo development rates after transfer of oocytes matured in vivo, in vitro, or within oviducts of mares. Animal Reproduction and Biotechnology. Philadelphia, v. 55, p. 705-715, 2001.

VARIAN, Hal R. Microeconomia, princípios básicos. Rio de Janeiro: Elsevier, 2006.

VASCONCELLOS, M. A. S. Economia: micro e macro: teoria e exercícios, glossário com os 260 principais conceitos econômicos. 2. ed. São Paulo: Atlas, 2001 
VIEIRA, E. R. Aspectos econômicos e sociais do complexo agronegócio cavalo no estado de Minas Gerais. 2011. 140 f. Dissertação (Título de Mestre) - Universidade Federal de Minas Gerais, Belo Horizonte, 2011. Disponível em:

http://www.bibliotecadigital.ufmg.br/dspace/handle/1843/BUOS-8NGF4E

Acesso em: 25 jan. 2016

VIEIRA, S. O que é hipismo? Rio de Janeiro: Casa da palavra, 2007.

ZYLBERSTAJN, D. Estruturas de governança e coordenação do agribussines: Uma aplicação da nova economia das instituições. 1995. 241 f. Tese (Título de Livre Docência) - Faculdade de Economia, Administração e Contabilidade - Universidade de São Paulo, São Paulo, 1995. Disponível em:

<http://200.144.188.9/PortalFEA/Repositorio/616/Documentos/Tese_Livre_Docencia_DZ.pd f>. Acesso em: 04 abr. 2014. 


\section{APÊNDICE A: QUESTIONÁRIO DIRECIONADO AOS CRIADORES DO CAVALO BH}

\section{UNIVERSIDADE DE SÃO PAULO}

1) Qual a biotecnologia de reprodução utilizada?

( ) Monta natural ( ) Transferência de embrião ( ) Inseminação artificial

2) As reprodutoras são do haras?

( ) Sim ( ) Não

3) Quantos animais fazem parte do plantel? Quantos (as) são utilizados (as) anualmente?

4) A propriedade utiliza seu (s) garanhão (ões) na reprodução ou em outras atividades? Quais?

5) A propriedade se utiliza de inseminação artificial? Qual o custo da dose? Qual o custo do trabalho associado?

6) A propriedade se utiliza da transferência de embrião? A propriedade possui receptora? Qual o custo dela? 
7) Qual a modalidade alvo do animal?

( ) CCE ( ) Salto ( ) Adestramento ( ) Indefinido

8) Os animais participam de competições?

( ) Sim ( ) Não

9) Todos os cavalos são registrados?

( ) Sim ( ) Não

10) Qual o custo da transferência de embriões?

11) Qual a idade de venda dos potros? Qual o valor de venda?

6_meses

12_meses:

24_a_48_meses:

$>48$ meses

12) Quantos funcionários o haras possui?

13) Quais os cargos e custo médio por cargos? 
14) Recebe assistência profissional? Quais?

15) Qual o custo da (s) assistência (s)?

16) Qual a base da alimentação dos animais?

( ) Forragem produzida no haras

( ) Forragem comprada

( ) Concentrado comprado

( ) Concentrado elaborado no haras

( ) Ingredientes

17) Custo da alimentação?

18) Custo do alojamento dos animais?

19) Custo com fármacos (vacina, vermífugo e remédios)? 
20) A propriedade tem ginete? Quantos? Qual o custo?

21) A variação nos custos de produção faz com que haja mudança na quantidade de animais que o haras pretende produzir?

( ) $\operatorname{Sim}($ ) Não

22) Caso disponível, seria utilizada alguma técnica para agregar valor ao animal?

( ) Sim ( ) Não

23) $\mathrm{O}(\mathrm{s})$ proprietário(s) possui(em) outra fonte de renda?

( ) Sim ( ) Não 


\section{APÊNDICE B: QUESTIONÁRIO DIRECIONADO AOS USUÁRIOS DO CAVALO DE ESPORTE}

\section{UNIVERSIDADE DE SÃO PAULO}

1) Onde seu animal é alojado?

( ) Hípica ( ) Haras ( ) Outros

2) Qual a modalidade o (s) animal (is) é (são) destinado (s)?

( ) CCE ( ) Salto ( ) Adestramento ( ) Outros:

3) Quantos animais possui?

4) São todos da raça $\mathrm{BH}$ ? Se não, qual a raça e destino? São todos registrados?

5) Qual o custo de aula/treinamento mensal?

6) Qual o custo da estabulagem/manutenção mensal?

7) Qual o custo mensal da alimentação?

8) No caso da prática de esporte, você é amador, profissional, criança ou sênior? 
9) Quantas pessoas utilizam o animal? Para quais finalidades?

10) O que motivou a compra do animal?

( ) Preço ( ) Nome do haras criador ( ) Resultados de animais da mesma linhagem em competições

( ) Versatilidade da raça ( ) Saúde do animal ( ) Qualidade do animal ( ) Outros especificar:

11) O que o cavalo é para você?

( ) Membro da família ( ) Lazer ( ) Esporte ( ) Profissão

12) Se for lazer, existe outra atividade? Qual?

13) Qual a frequência de uso do cavalo?

14) No caso da pratica de esporte, existe outra atividade? Qual a frequência?

15) No caso da pratica profissional, quantos cavalos são trabalhados diariamente? Quantos BHs?

16) O seu cavalo foi comprado para uso pessoal/ familiar ou para negócio? 
17) Se foi para negócio, qual a expectativa de valorização do animal?

18) Somando a sua renda, com a renda das pessoas que moram com você, quanto é, aproximadamente, a renda familiar mensal?
A) Nenhuma renda
B) Até $\mathrm{R} \$ 788,00$
C) $\mathrm{De} R \$ 788,00$ a $\mathrm{R} \$ 2.364,00$
D) $\mathrm{De} R \$ 2.364,01$ a $\mathrm{R} \$ 4.728,00$
E) De $\mathrm{R} \$ 4.728,01$ a $\mathrm{R} \$ 7.092,00$
F) De $R \$ 7.092,01$ a $R \$ 9.456,00$
G) De $R \$ 9.456,01$ a $R \$ 11.820,00$
H) Mais de $\mathrm{R} \$ 11.820,00$

19) Qual a sua renda mensal?
A) Nenhuma renda
B) Até $R \$ 788,00$
C) $\mathrm{De} R \$ 788,00$ a $\mathrm{R} \$ 2.364,00$
D) De $\mathrm{R} \$ 2.364,01$ a $\mathrm{R} \$ 4.728,00$
E) $\mathrm{De} R \$ 4.728,01$ a $\mathrm{R} \$ 7.092,00$
F) De R $\$ 7.092,01$ a $R \$ 9.456,00$
G) De $R \$ 9.456,01$ a $R \$ 11.820,00$
H) Mais de $\mathrm{R} \$ 11.820,00$

20) Qual a sua profissão?

21) Qual a sua idade?

22) Você trocaria a prática do hipismo por outras formas de lazer? Quais?

( ) $\mathrm{Sim}$ ( ) Não

23) Caso você fosse comprar um BH, e houvesse a expectativa de que o preço do animal iria subir, você anteciparia sua compra

( ) Sim ( ) Não 
24) Caso fosse comprar um animal e houvesse expectativa de queda no preço, você aguardaria para comprar o cavalo a um preço mais baixo?

( ) Sim ( ) Não

25) Por que você pratica hipismo? O que o esporte acrescenta na sua vida? 